\title{
CARACTERIZAÇÃO DA DRENAGEM E DO RELEVO DE TRES SOLOS DO ESTADO DE SÃO PAULO ATRAVÉS DE FOTOGRAFIAS AÉREAS E CARTAS PLANIALTIMÉTRICAS
}

\author{
RUBENS ANGULO FILHO
}

Orientador: Prof. Dr. VALDEMAR ANTONIO DEMÉTRIO

Tese apresentada à Escola Superior de Agricultura "Luiz de Queiroz", da Universidade de São Paulo, para obtenção do título de Doutor em Agronomia, Área de

Concentração: Solos e Nutrição de Plantas.

PIRACICABA

Estado de São Paulo - Brasil

Abril - 1986 
Rubens $€$ Regina, meus pais

Ada, minha esposá,

Luiz Felipe e Carlos Alberto,

meus irmãos,

pelo amor, incentivo e

compreensão,

OFEREÇO . 
Ao Prof. Dr. Valdemar Antonio Demétrio, do Departamento de Engenharia Rural da Escola Superior de Agricultura "Luiz de Queiroz", USP, pela orientação segura na elaboração deste traba1ho.

Ao Prof. Dr. Geraldo Victorino de França, Coordenador do Curso de Pós-Graduação em Solos e Nutrição de Plantas, da Escola Su perior de Agricultura "Luiz de Queiroz", USP, pelos ensinamen tos e inestimāvel colaboração.

Ao Departamento de Engenharia Rural da Escola Superior de Agricultura "Luiz de Queiroz", USP, através de seu Chefe, Prof. Dr. Antonio Petta, por possibilitar a realização desta Tese.

Ao Dr. Natálio Felipe Koffler, do IAA - PLANAL'SUCAR pelo empréstimo das fotografias aéreas utilizadas e sugestões apresentadas à elaboração do presente trabalho.

Ao Prof. Carlos Alberto Vettorazzi, do Departamento de Engenharia Rural da Escola Superior de Agricultura "Luiz de Queiroz", USP, pelo incentivo e colaboração na realização deste trabalho.

A Profa. Dra. Clarice Garcia Borges Demétrio, do Departamento de Matemática e Estatística da Esçola Superior de Agricultura Luiz de Queiroz", USP, pelas sugestões na análise estatística da presente pesquisa.

A todos que, direta ou indiretamente, contribuíram para a realização deste trabaiho. 
Lista dE FigURAS $\ldots \ldots \ldots \ldots \ldots \ldots \ldots \ldots \ldots \ldots \ldots \ldots \ldots \ldots \ldots \ldots$

RESUMO $\ldots \ldots \ldots \ldots \ldots \ldots \ldots \ldots \ldots \ldots \ldots \ldots \ldots \ldots \ldots \ldots \ldots \ldots \ldots$

SUMMARY $\ldots \ldots \ldots \ldots \ldots \ldots \ldots \ldots \ldots \ldots \ldots \ldots \ldots \ldots \ldots \ldots \ldots \ldots \ldots \ldots \ldots$

1. INTRODUÇOO $\ldots \ldots \ldots \ldots \ldots \ldots \ldots \ldots \ldots \ldots \ldots \ldots \ldots$

2. REVisá de literatura $\ldots \ldots \ldots \ldots \ldots \ldots \ldots \ldots \ldots \ldots$

2.1. Fotografias aéreas verticais no levantamento de $\operatorname{sol} 10 \mathrm{~s} \ldots \ldots \ldots \ldots \ldots \ldots \ldots \ldots \ldots \ldots \ldots$

2.2. O padxão de drenagem superficial: tipos, caracteristicas e significados .......... 11

2.3. Caracteristicas do relevo relacionadas a so-

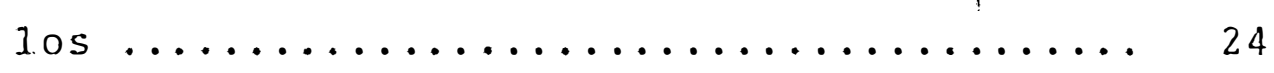

2.4. Verificação da precisão das cartas planialt $\underline{i}$

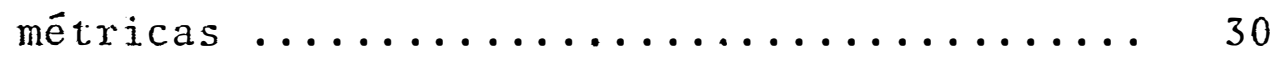

3. MATERIAL E METOdos ................... 32

3.1. Material ..................... 32

3.1.1. Descrição e localização das áreas de

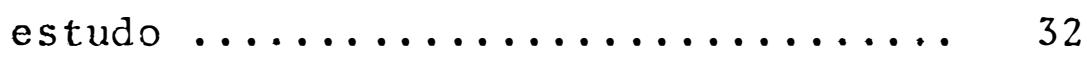

3.1.1.1. Localização geogräfica .... 32

3.1 .1 .2 . Relevo ............. 35

3.1.1.3. Geologia ............. 36

3.1 .1 .4$. C1ima $\ldots \ldots \ldots \ldots \ldots \ldots \ldots, 39$ 
3.1.1.5. Vegetação primitiva e uso atual da terra .......... 43

3.1 .1 .6$. Solos $\ldots \ldots \ldots \ldots \ldots \ldots \ldots$. 47

3.1.2. Material cartogräfico ......... 59

3.1.2.1. Cartas utilizadas para a caracterização da área A .... 59

3.1.2.2. Cartas utilizadas para a caracterização da ärea $B \quad \ldots . .61$

3.1.3. Material Fotogräfico ........... 62

3.1.4. Equipamentos ..................6 62

3.2. Métodos .........................6 63

3.2.1. Seleção das áreas de estudo ....... 63

3.2.2. Obtenção dos mapas básicos de drena -

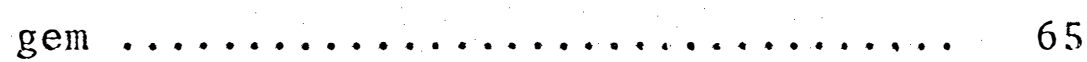

3.2.3. Análise das redes de drenagem ..... 66

3.2.4. Análise dos indices de relevo ......6 67

3.2.5. Anālise estatística $\ldots \ldots \ldots \ldots \ldots \ldots 71$

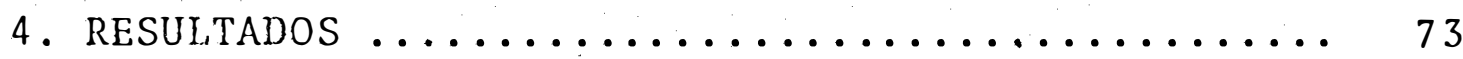

4.1. Características das amostras circulares .... 73

4.1.1. Geologia .................. 73

4.1.2. Solos .................... 74

4.2. Amostras circulares representativas da drena gem e do relevo .................... 74

4.3. Caracteristicas das redes de dreritgem ....... 75 4.3.1. Composição da rede de drenagem ..... 75 
Pägina

4.3.1.1. Nümero de rios ........ 75

4.3.1.2. Comprimento total de rios .. 75

4.3.2. Características do padrão de drenagem 75

4.3.2.1. Características descritivas do padrão de drenagem ..... 75

4.3.2.2. Caracteristicas quantitati vas do padrão de drenagem .. 100

4.4. Caracteristicas do relevo .............. 100 4.4.1. Características quantitativas dos parâmetros de relevo .............. 100

5. DiscussAo dos RESUltados $\ldots \ldots \ldots \ldots \ldots \ldots \ldots \ldots \ldots \ldots$

5.1. Caracteristicas das amostras circulares .... 104 5.1.1. Latossolo Verme1ho-Amare1o ....... 104 5.1.2. Podzólico Vermelho-Amarelo ........ 105 5.1.3. Litossolo ................ 105

5.2. Amostras circulares representativas da drena gem e do relevo .................. 106

5.3. Anâlise da rede de drenagem ........... 107 5.3.1. Composição da rede de drenagem ..... 107 5.3.1.1. Número de rios .......... 107 5.3.1.2. Comprimento total de rios .. 107

5.3.2. Anâlise das características do padrão de drenagem ................. 108 5.3.2.1. Características descritivas do padrão de drenagem ...... 108 
.vii.

Pägina

5.3.2.2. Características quantitati vas do padrão de drenagem .. 109

5.4. Anālise das características do relevo ..... 112

5.4.1. Caracteristicas quantitativas dos parâmetros de relevo ................ 112

5.4.1.1. Declividade média ........ 112

5.4.1.2. Amplitude altimétrica māxima 114

5.4.1.3. Comprimento médio das vertentes.................... 115

5.5. Anâlise dos resultados dos parâmetros de relevo obtidos de cartas planialtimêtricas em

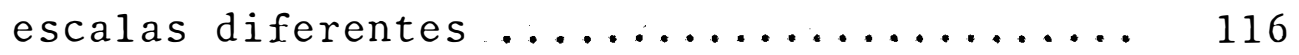

5.5.1. Declividade média ............. 116

5.5.2. Amplitude altimétrica máxima ....... 117

5.5.3. Comprimento médio das vertentes .... 117

6. CONCLUSOES ............................. 119

7. Literatura CITADA ..................... 121 
1 Dados de temperatura e precipitação de quatro localidades da Area A. (Fonte: OLIVEIRA

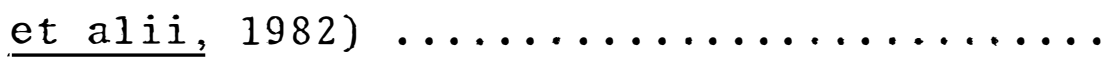

2 Dados de temperatura e precipitação para quatro localidades da Area B. (Fonte: OLI-

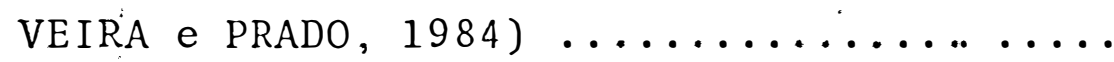

3 Médias seguidas dos respectivos erros padrões, de resultados de amostras da camada superficial (a) e subsuperficial (b), de vârias características da unidade Laranja zeda (1). (Fonte: OLIVEIRA et alii, 1982).

4 Médias seguidas dos respectivos erros padrões, de resultados de amostras da camada superficial (a) e subsuperficial (b), de vâ rias características da unidade Olaria. (Fonte: OLIVEIRA et alii, 1982) ......... 55

5 Características Analíticas da Unidade Santa Cruz. (Fonte: OLIVEIRA e PRADO, 1984) .....

6 Número de rios observados em cada ordem e o total para as amostras circulares; médias e respectivos erros padrões .............

7 Comprimento total de rios para as amostras circulares; médias e respectivos erros pa-

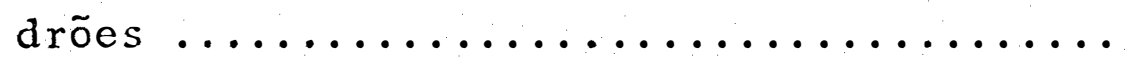


8 Características descritivas das redes de drenagem, dos três solos estudados, segundo LUEDER (1959), tipo ou modelo segundo

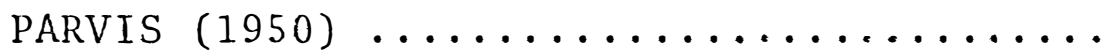

9 Características quantitativas do padrão de drenagım, valor médio e erro padrão da mé dia, das amostras circulares representati vas dos solos em estudo ................ 101

10 Características quantitativas dos parâmetros de relevo, valor médio e erro padrão da média, das amostras circulares dos solos em estudo (Carta planialtimétrica $E=1: 10.000)$.

11 Características quantitativas dos parâmetros de relevo, valor médio e erro padrão da média, das amostras circulares dos solos em estudo (Carta planialtimétrica $E=1: 50.000) . \quad 103$ 
7 Representação esquemâtica da forma de leitura do comprimento médio da ver tente. (Fonte: VALERIO FILHO, 1984) . 71

8 Representação das formações geológicas que constituem as amostras de Latossolo Vermelho-Amarelo ............. 76

9 Representação das formações geológi cas que constituem as amostras de Pod

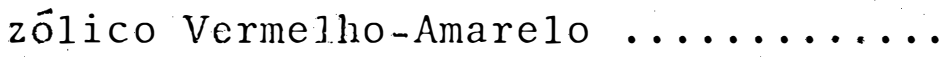

10 Representação das formações geológi cas que constituem as amostras cjrcu-

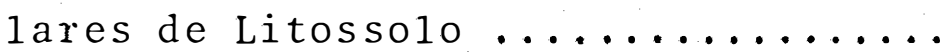

11 Amostras Circulares de Latossolo-Vermelho -Amarelo, retiradas da Carta de Solos do Levantamento Pedológico Semi detalhado do Estado de Sçao Paulo:

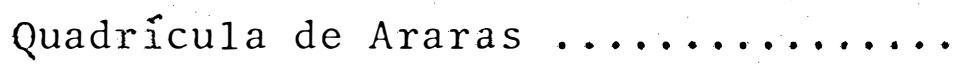

12 Amostras Circulares de Podzólico Ver me1ho-Amarelo, retiradas da Carta de Solos do Levantamento Pedológico Semi detalhado do Estado de São Paulo: Quadrícula de Araras ........... 80 


\section{I.ISTA DE FIGURAS}

FIGURA

Pâgina

1 Localização da área de onde foram retiradas as amostras circulares de LatossoloVermelho-Amarelo e Podzôlico Vermelho-Ama relo $\ldots \ldots \ldots \ldots \ldots \ldots \ldots \ldots \ldots \ldots$

2 Localização da área de onde foram retiradas as amostras circulares de Jitossolo.

3 Balanço hídrico segundo método de "Thorth waite e Mather - 1955" para quatro locali dades da Area A. (Fonte: Ol,IVEIRA et alii

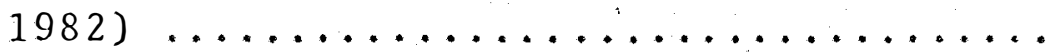

4 Balanço hídrico segundo método de "Thorth waite e Mather - 1955" para quatro locali dades da Área B. (Fonte:OLIVEIRA e PRADO,

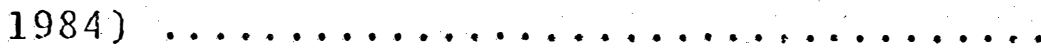

5 Modelo da amostragem de WENTWORTH (1930) adaptado por KOEFLER (1982) ...........

6 Representação esquemâtica do sistema de leitura da amplitude altimétrica máxima. (Fonte: VALERIO FILHO, 1984) ......... 
13 Amostras Circulares de Litossolo, retiradas da Carta de Solos do Levantamento Pedológico Semidetalhado do Estado de São Paulo: Qua

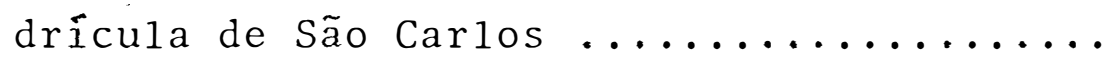

14 Amostras Circulares LV-1, LV-2 e LV-3

$\left(10 \mathrm{~km}^{2}\right)$ da rede de drenagem em Latossolo

Verme1ho-Amare10. Escala $1: 35.000 \ldots \ldots \ldots$

15 Amostras Circulares PV-1, PV-2 e PV-3

$\left(10 \mathrm{~km}^{2}\right)$ da rede de drenagem em Podzólico Verme1ho-Amare10. Escala $1: 35.000 \ldots \ldots \ldots$

16 Amostras Circulares Li-1, Li-2 e Li-3

$\left(10 \mathrm{~km}^{2}\right)$ da rede de drenagem em Litossolo.

Escala $1: 35.000 \ldots \ldots \ldots \ldots \ldots \ldots$

17 Amostra Circular, LV-1 $\left(10 \mathrm{~km}^{2}\right)$, do relevo em Latossolo Verme1ho-Amare1o. Escala 1:10.000

18 Amostra Circular, LV-2 $\left(10 \mathrm{~km}^{2}\right)$, do relevo em Latossolo Verme1ho-Amare1o. Escala 1:10.000

19 Amostra Circular, LV-3 $\left(10 \mathrm{~km}^{2}\right)$, do relevo em

- Latossolo Verme1ho-Amare1o. Escala 1:10.000

20 Amostra Circular, PV-1 $\left(10 \mathrm{~km}^{2}\right)$, do relevo em Podzólico Vermelho-Amarelo. Escala 1:10.000 Amostra Circular, PV $-2\left(10 \mathrm{~km}^{2}\right)$, do relevo em Podzólico Vermelho-Amare1o. Escala 1:10.000 
22 Amostra Circular, PV-3 $\left(10 \mathrm{~km}^{2}\right)$, do relevo em Podzólico Verme1ho-Amare1o. Escala 1:10.000

23 Amostra Circular, Li-1 (1okm²), do relevo em Litossolo. Escala 1:10.000,..........

24 Amostra Circular, Li-2 $\left(10 \mathrm{~km}^{2}\right.$ do relevo em Litossolo. Escala $1: 10.000 \ldots \ldots \ldots$

25 Amostra Circular, Li-3 (10 km²), do relevo em Litossolo. Escala $1: 10.000 \ldots \ldots \ldots \ldots$

26 Amostras Circulares, LV-1, LV-2 e LV-3 $\left(10 \mathrm{~km}^{2}\right)$, do relevo em Latossolo Vermelho Amarelo. Escala $1: 50.000 \ldots \ldots \ldots \ldots$

27 Amostras Circulares, PV-1, PV-2 e PV-3 $\left(10 \mathrm{~km}^{2}\right)$, do relevo em Podzólico VermelhoAmarelo, Fscala $1: 50.000 \ldots \ldots \ldots \ldots$

28 Amostras Circulares, 1 i-1, Li-2 e Li-3 $\left(10 \mathrm{~km}^{2}\right)$, do relevo em Litossolo. Escala

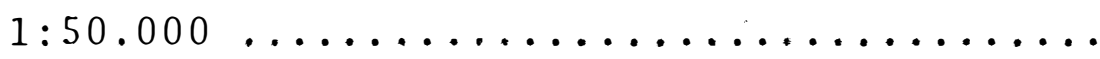

29 Gráfico Representativo dos Valores Médios dos Indices de Drenagem e Respectivos Erros Padrão da Média, para os Três Solos Estuda-

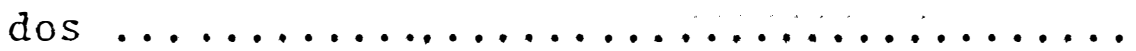

30 Grä́ico Representativo dos Valores Médios dos Parâmetros de Relevo e Respectivos Erros Padrão da Nédia para os Três Solos Estudados ............... 
.$x i v$.

CARACTERIZAÇÃO DA DRENAGEM E DO RELEVO DE TRẼS

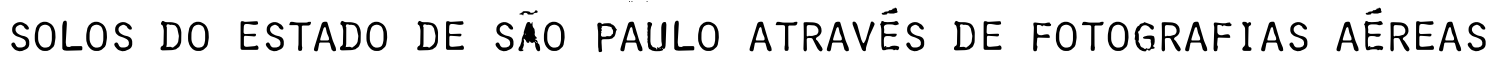

E CARTAS PLANIALTIMETRICAS

Autor: Rubens Angulo Filho

Orientador: Valdemar Antonio Demëtrio

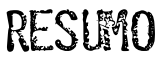

Com base na interpretação de fotografias aêreas verticais na escala $1: 35.000$, fez-se caracterização de três solos do Estado de São Paulo e determinou-se a variação dos indices de relevo obtidos de cartas planialtimétricas em escalas diferentes.

A área de trabalho localiza-se, entre os parale$\operatorname{los} 22^{\circ} 00^{\prime} \mathrm{S}$ e $22^{\circ} 30^{\prime} \mathrm{S}$ e os meridianos $47^{\circ} 00^{\prime} W G$ e $48^{\circ} 00^{\prime} W G$; nesta área foram estudados os seguintes solos:

a) Latossolo Verme1ho-Amare1o;

b) Podzólico Verme1ho-Amare1o;

c) Litossolo.

Cada unidade de solo foi representada por três amostras circulares de $10 \mathrm{~km}^{2}$.

Dos decalques das redes de drenagem feitos sobre as fotografias aéreas verticais, nas amostras circulares foram 
foram determinados os indices quantitativos dos padrões de drenagem (densidade de drenagem, freqüencia de rios e razão de textura).

Os indices de relevo (declividade média, amplitu de altimétrica máxima e comprimento médio das vertentes) foram obtidos das amostras circulares decalcadas sobre as seguintes cax tas planialtimétricas: a) carta planialtimétrica na escala 1:10.000 com equidistância vertical de $5 \mathrm{~m}$, do Instituto Geográfico e Cartográfico (IGC); b) carta planialtimétrica na escala $1: 50.000$ com equidistância vertical de $20 \mathrm{~m}$, do IBGE. Posteriormen te, os valores dos indices de relevo obtidos das duas cartas foram comparados para a determinação de sua variação.

A interpretação dos dados obtidos, com o material e métodos empregados nas condições do estudo, permitiram obter as seguintes conclusões:

- os indices de drenagem utilizados foram eficientes na diferenciação dos solos estudados;

- os indices de relevo, também foram eficientes na discriminação dos três solos estudados;

- as cartas em escala maior e que têm maior capa cidade de detalhar o relevo das âreas em estudo são mais confiáveis para caracterizar quantitativamente o relevo; além disto, para diferenciar solos que se encontram em relevo acidentado seme 1hante, a utilização das cartas planialtimétricas que detalham mais o relevo fornecerão resuj.tados mais dignos de confiança;

- as características qualitativas das redes de drenagem não foram eficientes na diferenciação dos três solos es- 
.$x v i$.

tudados;

- a caracterização quantitativa e análise dos indices de drenagem e relevo, utilizando-se apenas as médias e er ro padrão das médias, foi suficiente para mostrar diferenças entre os solos analisados. 


\title{
CHARACTERIZATION OF DRAIHAGE AND OF RELIEF TROUGH \\ AERIAL PHOTOGRAPHS AND PLANIALTIMETRIC CHARTS FOR THREE \\ SOILS OF THE SAO PAULO STATE
}

\author{
Author: Rubens Angulo Filho \\ Adviser: Valdemar Antonio Demétrio
}

\section{SUMPMARY}

Based on the interpretation of vertical aerial photographs on a $1: 35000$ scale, the characterization was made of the drainage standards for three different soils of the São paulo State and the variation was determined for the relief indices obtained from planialtimetric charts on different scales.

The experiment area is sutuated between parallels $22^{\circ} 00^{\prime} \mathrm{S}$ and $22^{\circ} 30^{\prime} \mathrm{S}$, and meridians $47^{\circ} 00^{\prime} \mathrm{WG}$ and $48^{\circ} 00^{\prime} \mathrm{WG}$. The following soils of this, area were studied:
a) Red-Ye11ow Latosol
b) Red-Yellow Podzolic
c) Litosol

Each soil unit was represented by three circular samples of $10 \mathrm{~km}^{2}$.

From tracing the drainage networks on the vertical aerial photographs, the quantitative indices for the drainage standards were determined for the circular samples (drainage density, 
frequency of rivers and ratio of texture).

The relief indices (mean declivity, maximum altimetric amplitude and mean length of slope) were obtained from the circular samples traced on the following planialtimetric charts: a) planialtimetric chart on a $1: 10000$ scale with $5 \mathrm{~m}$ of vertical equidistance, by the Instituto Geogräfico e Cartogräfico; b) planialtimetric chart on a $1: 50000$ scale with $20 \mathrm{~m}$ of vertical equidistance, by JBGE. Subsequently, the values for the relief indices obtained from the two charts were compared to determine their variation.

The interpretation of the data obtained with the material and methods utilized in the study led to the following conclusions:

- the drainage indices utilized were shown to be efficient for differentiating the soils under study;

- the relief indices were also effjcient in discriminating the three soils studied;

- that charts on larger scale, which provide greater detailing of the relief of the areas under study, are more reliable to characterize the relief quantitatively, in addition, to differentiate soils with similar relief, the utilization of more detailed planialtimetric charts provide more reliable results;

- the qualitative characteristics of the drainage networks were not efficient in differentiating the three soils under study; 
- the quantitative characterization and analysis of the drainage and relief indices, utilizing only the mean values and standard error of means, was sufficient to demonstrate the differences between the studied soils. 


\section{INTROUUCÃO}

Dentre as alternativas viáveis para o aumento da produtiviade, uma das mais importantes é o manejo ad€quado dos solos agrícolas. A racionalização do manejo dos solos requer o conhecimento de suas características, o que é conseguido através do levantamento pedológico.

Para este tipo de trabalho, a fotointerpretação tem-se revelado do mais alto valor como processo de coleta de dados, pois as imagens fotogräficas substituíram, quase que com pletamente, as outras bases cartográficas no mapeamento dos solos, apresentando como principal vantagem a riqueza de detalhes do terreno, que permite ao pedólogo locaíizar e traçar os limi tes dos solos com precisão e economia de tempo.

Entre os elementos de interesse que podem ser ob servados na fotografia aérea, que se correlacionam com os solos sobre os quais se encontram, a rede de drenagem tem sido 
o de mais fâcil interpretação, alêm de ser um dos mais eficazes para a caracterização das unidades de solo.

Além dos ínaices retirados da rede de drenagem, os de relevo, que são obtidos a partir de cartas planjaltimétricas têm-se mostrado muito eficazes na diferenciação de solos.

Assim sendo, com base nas hipóteses de FROST (1960) de que solos semelhantes apresentam padrões se melhantes e que solos diferentes apresentam padrões diferentes, e de CHRISTOFOLETTI (1969) que diz que a movimentação do relevo age como fator importante na densidade da drenagem, pois as áreas de relevo mais movimentado possuem trama mais densa dos canais que as áreas de relevo suave, o que permite inferir que áreas de relevo diferentes possuem solos diferentes, elaborou-se este trabalho que tem os seguintes objetivos:

- testar a eficácia de alguns indices de drenagem e de relevo, na diferenciação das três unidades de solos: Latossolo Vermelho-Amarelo, Podzólico Vermelho-Amarelo e Litos solo;

- comparar os resultados dos indices de relevo que foram obtidos de cartas planialtimétricas em escalas diferentes $(1: 10.000$ e $1: 50.000)$. 


\section{REVISÃO DE LITERATURA}

\subsection{Fotografias aÉREAS. Verticais no LeVANTAMEnto de solos}

As fotografias aéreas verticais constituem excelente ferramenta de trabalho para o levantamento de solos. A li teratura especializada mostra grande número de trabalhos onde os autores evidenciam a utilidade das fotografias aéreas, ressa 1 tando as vantagens e restrições a que estão sujeitas.

Para SIMONSON (1950), o maior avanço em levantamento de solos nas duas décadas anteriores a 1950, foi a utilização de fotografias aéreas.

Segundo QUACKENBUSH (1960), a evolução do uso da fotografia aérea foi simultâneo ao desenvolvimento do material e equipamen to fotográfico, mas somente no século XX, com o apoio da aero náutica, progrediu até o ponto de permitir a obtenção de imagens 
da superfície terrestre, por meio de fotografias tomadas de aeronaves.

GOOSEN(1968) disse que a visão panorâmica que as fotografias aéreas proporcionam, como um meio de documentação e pesquisa dos fenômenos da paisagem, não tem rival a um custo com parável. Admite ainda que, embora o trabalho de campo não seja substituído completamente pela fotografia aérea, o rendimento e a exatidão dos trabalhos são altamente favorecidos. 0 autor tam bém admitiu que a utilização da fotointerpretação é mais importante em levantamentos de reconhecimento do que em levantamentos detalhados.

A fotografia aérea, para AMARAL e AUDI (1972), aㅡ presenta-se como material de trabalho indispensável no levantamento de solos, oferecendo ganho de tempo, precisão de limites e real visão global da paisagem com riqueza de detalhes. Ela ser ve não só como base cartográfica preliminar, auxiliando os trabalhos de campo no traçado de roteiros mais interessantes, como também possibilita a separação das unidades de solo diretamente sobre as fotografias.

LUEDER (1959) concluiu que, em mapeamentos de re conhecimento, o esforço de trabalho, usando a fotointerpretação, corresponde a um décimo do que seria necessário sem sua utiliza ção; e para os levantamentos detalhados a economia de tempo varia de dez a noventa por cento.

BASTOS (1966) comenta trabalho descrito por VERA (1964), referente ao Projeto Aerofotogramétrico OEA-CHlLE, no qual $120.000 \mathrm{~km}^{2}$ 
de terras agrícolas tiveram os seus solos levantados a nível de talhado num período de 18 meses. O autor faz a observação que as informas̃ões obtidas neste curto espaço de tempo, sem o uso de técnicas aerofotogramétricas e fotointerpretativas, levaria um tempo superior ao de uma vida humana.

Apesar das vantagens apresentadas pelas fotogra fias aéreas nos levantamentos de solos, o trabalho de campo não pode ser substituído completamente, conforme advertem BOMBERGER e DILL (1960). Segundo estes autores, as fotografias aẻreas mos tram apenas a superfície do solo, que muitas vezes não está ví sível. Salientaram porém a presença de padrões, tais como os de relevo, drenagem, erosão, vegetação, que permitem ao fotointér.prete fazer inferências sobre a distribuição dos solos e seu material de origem.

COLWELL (1952) definiu fotointerpretação como o ato de examinar imagens fotográficas de objetos com a finalidade de identificá-los e avaliá-los quanto a sua significância, en quanto que SUMMERSON (1954), de maneira ampla, definiu-a como sendo a previsão do que não pode ser visto. Esta afirmativa pos sui maior afinidade com a interpretação fotográfica de solos, pois a fotografia aérea mostra somente a superfície do terreno e não as variações que ocorrem em profundidade, caracterizando uma unidade de solo. Mas os variados aspectos de ocorrência na superfície, tais como vegetação, formas topogräficas, drenagem, erosão, tonalidade fotográfica e uso da terra, podem indicar a presença de solos diferentes. 
RABBEN (1960) explicou a larga utilização da fotografia aérea baseado em três fatos fundamentais:

a) cada fotografia aérea representa uma grande área da superfície terrestre, sendo aproximadamente de $20 \mathrm{~km}^{2}$ na escala $1: 20.000$ e $33 \mathrm{~km}^{2}$ na escala $1: 25.000$;

b) os pares estereoscópicos proporcionam imagens tridimensionais da superfície terrestre e dos objetos sobre ela localizados;

c) as fotografias aéreas proporcionam um caráter permanente das imagens, possibilitando medições e melhores condições de trabalho.

Segundo RABBEN (1960), há duas maneiras para se estudar imagens aerofotográficas. Uma totalmente empírica, que consiste no exame minucioso de todo material fotogrä́fico existente, sem se omitir nada. Outra maneira, é utilizar-se de probabilidades, isto é, o intérprete pesquisa somente as áreas nas quais os objetos de interesse podem ser encontrados, desprezando grande número de fotografias que não têm probabilidades de conter as informações desejadas. Isto é "pesquisa lógica", uma combinação de visão geral e estudo intensivo, que exige maior ex periência, já que o intérprete deve decidir onde os estudos terão melhores resultados, mas é mais produtiva em relação ao tem po e esforços dispendidos. Comenta ainda que, para identificar ob jetos nunca vistos anteriormente, ou para entender o significado de objetos já identificados, o intérprete utiliza o "princípio da convergência de evidências", desenvolvido por Colwell: 
"podem existir vários indj́cios sobre a identidade de um objeto desconhecido; nenhum destes indícios é infalível, mas se todos, ou a maioria dos indícios apontar para a mesma conclusão, esta serā provávelmente correta". Assim, RABBEN (1960) acredita que a fotointerpretação é na realidade uma arte de probabilidades e refere-se ao termo "chave de interpretação", como auxiliar do intërprete, no sentido de organizar as informações presentes em imagens fotográficas aéreas, guiando-o para a identificação cor reta dos objetos desconhecidos.

Para FROST (1960), a interpretação de solos em fotografias aéreas pode ser feita utilizando-se três inportantes principios:

a) solos semelhantes ocorrem com padrões semelhantes;

b) solos diferentes apresentam padrões diferentes;

c) correlações de características da imagem fotográfica com propriedades do solo observadas no campo e no laboratörio, podem ser inferidas por fotointerpretação.

FROST (1960) salientou ainda a importância do es tudo de aspectos regionais mostrados em mosaicos fotográficos, antes de examinar o detalhe, a fim de que grandes feições regio nais possam ser relacionadas aos fatores ambientais como fisio grafia, geologia e clima. Acredita que o estudo de solos no con texto regional habilita o cientista do solo à posterior interipretação de fotografias de regiões desconhecidas.

0 estudo de fotografias aéreas é geralmente feito em duas etapas, conforme sugeriram RABBEN (1960), RAY (1963)e 
RICCI E PETRI (1965). A primeira consiste na observação, coleta de dados, medição e identificação das imagens tridimensionais nas fotografias aéreas. A segunda consiste na indução e ou dedu ção de fenômenos ou de relações, incluindo a aplicação das informações obtidas na solução de problemas.

Shultz e Cleaves, citados por RAY (1963), afirma ram ser a forma fisiográfica o elemento mais importante para a fotopedologia; contudo, a drenagem e o relevo podem fornecer in formações de mesma importância.

Segundo LUEDER (1959), com exceção da forma fisiográfica, o mais seguro inảicador das condições do terreno é a drenagem superficial, sendo porém imprescindível a experiên cia do fotointérprete no estabelecimento das correlações entre imagem fotográfica e aspectos do terreno.

DUNBAR (1959), ao discutir alguns aspectos fotointerpretativos em solos de regiões tropicais, referiu-se parti cularmente a certas áreas do Brasil onde alguns latossolos argi losos têm aparência de solos com textura areno-barrenta nas fotografias aëreas, apresentando: porosidade relativamente elevada, ângulo de repouso moderadamente íngreme e padrão de drenagem esparso, pouco integrado. Ele associou este fato à ação intensa do intemperismo e erosão.

Para BURINGH (1960), em levantamentos de solos sem fotointerpretação, aproximadamente $20 \%$ das observações de campo são gastas para identificação e classificação dos solos e o res tante do tempo para localizar os limites dos solos; com auxílio 
de fotointerpretação, grande parte destes limites seriam demar cados nas fotografias, sendo necessārias apenas algumas verificações de limites no campo.

Para a fotointerpretação empregada em levantamen tos de solos, existem três mëtodos preconizados por GOOSEN (1968):

a) "Anālise de "padrões" de FROST (1960), que con siste no estudo dos padrões indicativos das condições superfi ciais e de subsuperfície, como a fisiografia, drenagem, aspectos de erosão, vegetação, tonalidade fotogräfica e uso da terra. Após conhecimento das condições ambientais dos solos estudados, o fotointérprete divide as unidades principais da paisagem em $\underline{u}$ nidades menores e examina os padrões locais, em estereoscopia;

b) "Anālise fisiogräfica", citada por BURINGH (1960), que necessita de conhecimento profundo de processos fisiogräficos e seus reflexos na interpretação das fotografias aẻreas. O terreno é classificado segundo unidades fisiogräficas, as quais correspondem a uma associação única de solos;

c) "Anālise de elementos", desenvolvida por BURINGH (1960), que apresenta como vantager, a utilização por pedólogos com pouca experiência em fotointerpretação. Consiste na anảlise sistemätica dos elementos relacionados com as condições de solo de uma região, baseada na relação existente entre caracte rísticas da superfície do terreno e condições do solo. Utilizan do-se a convergência de evidências, separam-se as unidades pedo lógicas identificadas pela mudança em um ou mais elementos.

GOOSEN (1968) explicou que o objetivo da anālise de 
fotografias aëreas em levantamentos de solos, é chegar a uma classificação da superfície do terreno que, através de trabalhos de campo subsequentes e análises de laboratório, possa ser traduzido em unidades de mapeamento. Comentou ainda que a diferenciação entré os métodos e sua utilização é relativamente artificial, pois na prática pode ocorrer uma combinação dos trēs mé todos, dependendo da maneira como é feito o levantamento. Em um trabalho generalizado pode ser necessäria uma ampla análise fisiogräfica preliminar para se determinar a divisão fisiográfica da paisagem. Feito j.sto, pode-se estudar em detalhe áreas de amostragem, atravês da análise dos elementos. Isto resultou no esta belecimento de chaves para mapear as demais partes da ärea por meio da análise de padrões. Assim, nenhum procedimento sistemático pode ser preconizado, no estado atual dos conhecimentos, aos técnicos de fotointerpretação.

Os princípios propostos pelo método da "análise de elementos" foram utilizados por FRANÇA (1968), MARCHETTI (1969), FAIEL (1972), LEÃO (1972), VASQUES FILHO (1972), GEVAERD (1974), SOUZA (1975), KOFFLER (1976a), FREIRE (1977), DEMETRIO (1977), CARVALHO (1977), Silva (1977), NOGUeIRA (1979), POLITANO (1980), ANGULO FILHO (1981), MANECHINI (1981), VALERIO FILHO (1984), VETTORAZZI (1985) entre outros, sobre fotografias aéreas verticais, estabelecendo-se parâmetros para a identificação de algumas unidades de solo nas condições brasileiras. 


\subsection{O PADRÃO DE DRENAGEM SUPERFICIAL: TIPOS, CARACTERÍSTICAS E SIGNIFICADOS}

A análise da rede de drenagem permite a compreen são e elucidação de numerosas questões geomorfológicas, porque os cursos d'água são processos morfogenéticos bastante atuantes na esculturação da paisagem terrestre. A sua importância na geo morfologia clássica e nos estudos cartográficos e aerofotogramé tricos pode ser mostrada pelo fato da drenagem encontrar-se intimamente relacionada, como fator analítico, à erosão, outro elemento fisiográfico e geomorfológico de extraordinária importância (CHRISTOFOLETTI, 1969).

Os padrões de drenagem auxiliam na fotointerpretação porque podem ser usados como critérios na identificação de fenômenos geológicos, hidrológicos, geomorfológicos e pedológicos pois, segundo LUEDER (1959), o padrão de drenagem, com exce ção do relevo, é o mais consistente e confiável indicador das condições do terreno, disponível ao fotointérprete.

Para PARVIS (1950), a relativa facilidade com que

- os sistemas de drenagem podem ser observados em fotografias aéreas, facilita o reconhecimento de padrões de drenagem, o estudo analítico de seus elementos e a avaliação de sua significância na interpretação de solos e de substratos rochosos.

SOUZA (1975) comentou que as dificuldades para delimitar unidades de solo no campo, devido à falta de acesso, podem ser perfeitamente contornadas, utilizando-se os aspectos 
visiveis nas fotografias aéreas. Dentre os padrões que permitem a diferenciação de solos, as redes de drenagem, juntamente com o relevo, são os que maís se destacam, com vantagem para as redes de drenagem, que são mais facilmente registradas e medidas em fotografias aéreas.

WEG (1966) subdividiu os padrões de drenagem em: (1) padrões erosionais, que são formados por algum processo degradante de erosão, e cujos modelos se repetem em frequência; (2) paärões deposicionais, os desenvolvidos por processos construcionais de deposição, estando muito relacionados ao padrão do canal; (3) padrões especiais, todos aqueles que não são clas sificados pelos critêrios anteriores.

Para BLOOM (1970), padrão de drenagem diz respe $\underline{i}$ to aos aspectos específicos do arranjamento bidimensional e ca sualizado assumido pela imagem fotográfica da rede de drenagem e estabelece cinco tipos de arranjamento: caótico, dendrítico, retangular, treliça e radial.

PARVIS (1950) classificou os padrões de drenagem em dois grupos: básicos e modificados, e apresentou seis padrões de drenagem básicos: dendrítico, treliça, radial, paralelo, anu lar e retangular. Utilizando de algumas modificações destes seis padrões básicos, classificou e descreveu cerca de trinta tipos ou modelos.

Segundo HORTON (1945), o desenvolvimento de bacias hidrográficas e de suas redes de drenagem deve ser discutido em termos de infiltração, deflúvio e erosão, em terrenos 
recentemente expostos. No entanto, node haver interferência de estruturas geológicas ou distúrbios geológicos, posteriormente. Deste modo, quando ocorrem afastamentos das leis dos nümeros e dos comprimentos de rios em condições normais de topografia,cli ma, geologia, solo, etc., esses afastamentos podem estar condicionados ao controle de estruturas geológicas.

Para FRANÇA (1968), o termo padrão de drenagem tem sido usado na literatura para expressar a maneira pela qual os cursos d'água se arranjam ou se distribuem numa determinada área de drenagem, segundo modelo ou configuração de um objeto familiar, que empresta o nome para classificação do padrão. Se os rios se distribuem à semelhança de tronco, galhos e ramos de uma árvore, o padrão é chamado dendrítico ou arborescente; se po de ser comparado aos ramos de uma videira é denominado padrão em treliça e assim por diante.

Segundo LUEDER (1959), a diferenciação dos padrões de drenagem com base exclusiva em termos designativos, te rá valor limitado se a classificação do padrão não for completa da com a descrição de certas características, variáveis dentro de cada padrão, e que podem indicar aspectos significativos. As sim, sugeriu as seguintes características para descrever o pa drão de drenagem: grau de integração, densidade, grau de unifor midade, orientação, grau de controle, ângulos de confluência, angularidade, tipo ou modelo.

O termo anomalia foi acrescentado por RICCI e PETRI (1965), na lista de caracteristicas descritivas, para representar qual 
quer configuração que não se adapta àquela dominante, apresenta da por todos os outros rios da ärea. LUEDER (1959) recomendou que os termos descritivos sejam aplicados somente à drenagem des trutiva, isto é, cujo padrão é criado por erosão hídrica.

VETTORAZZI (1985) observou que, na região do rio Ribeira de Iguape, as características descritivas do padrão de drenagem não foram eficientes na diferenciação entre as unida des de solo estudadas.

Para LUEDER (1959), a justificativa principal da análise de drenagem superficial é que fornece indicações sobre a razão infiltração/deflīivio, capacidade de infiltração, permea bilidade e textura dos materiais que ocorrem em uma área. Em ge ral, um padrão de drenagem bem desenvolvido indica a ocorrência de baixa infiltração e materiais relativamente impermeáveis, en quanto que uma drenagem superficial escassa indica infiltração e permeabilidade altas. Como sempre, existem exceções e casos especiais, mas como regra geral é muito eficiente. Esclareceu também que o padrão de drenagem não é influenciado apenas pela composição do material, havendo outros fatores, como a topografia do terreno.

0s padrões de drenagem, segundo RAY (1963), podem ser aplicados na interpretação geológica. Âreas onde a resistência à erosão é mais ou menos uniforme, como em muitos depósitos sedimentares ou mantos de intemperismo sobre embasamentos sem estrutura pronunciada, o padrão de drenagem é comumente dendritico ou dendritico modificado. Onde existe maior controle 
estrutural, desenvolvem-se padrões em treliça, anular, retangular etc. Também comentá que, sendo pronunciada a sensibilidade da dre nagem à direção geral e direções de mergulho, as mudanças num padrão de drenagem, ou desvios de uma norma estabelecida, podem for necer informações muito importantes.

Ainda segundo RAY (1963), a densidade de drenagem em um dado ambiente climático está relacionada principalnente com a resis tência à erosão dos materiais presentes, aumentando a densidade à medida que diminui a resistência à erosão. Examinando fotografias aéreas, afirmou que folhelhos e outras rochas similares de granulação fina tendem a a presentar drenagem de textura fina, enquanto que rochas sedimentares de granulação grossa, como arenitos, tendem a apresentar drenagem de textura grosseira. Entretanto, admitiu que podem existir muitas exceções. FRANÇA (1968) afirmou que muitas das exceções são devidas à natureza dos solos que se desenvolvem sobre essas rochas.

ZINKE (1960) considerou plausivel que o solo deri vado de um tipo de rocha relativamente impermeável, conduzirá a maiores proporções de deflúnio e, consequentemente, a um maior desenvolvimento de sua rede de drenagem superficial.

DUNBAR (1959), ao discutir os problemas de inter - pretação fotográfica em regiões tropicais e subtropicais, aler tou para o fato que solos latossólicos, com elevado teor de argila, podem apresentar redes de drenagem com características se melhantes às que ocorrem em solos de classe textural areia barrenta.

Citando trabalho de Jenkis et alii, RAY (1963) es 
clareceu que as fotografias aéreas mostram a drenagem efetiva do perfil, independentemente da textura ou composição granulométrica do solo. Ainda se reportando a esses autores, lembra que o calcá rio origina solo de partículas finas, porém agregadas, resultan do perfis permeáveis e bem drenados internamente e, consequente mente, as fotos aéreas mostram uma rede de drenagem superficial de textura grosseira.

As afirmativas de DUNBAR (1959) e RAY (1963) foram confirmadas por FRANÇA (1968) e FADEL (1972), ao verifica -rem que solos argilosos dos grandes grupos Latossol Roxo e La tossol Vermelho Escuro, graças à sua estrutura porosa, apresentaram-se mais permeáveis que solos arenosos do grande grupo Pod zólico Vermelho-Amarelo variação Laras.

ESPINDOLA e GARCIA (1978) encontraram maiores

variações no índice densidade de drenagem para os solos com B textural, em comparação aos solos com B latossólico.

Para HORTON (1945), além de outros fatores como precipitação e relevo, dois são importantes nos processos de erosão hỉdrica, responsáveis pela gênese de sistemas hidrográf cos e suas bacias de drenagem, são a resistência dos solos à erosão e sua capacidade de infiltração; sendo que, se considerado um longo período de tempo, em qualquer área sujeita à erosão por água corrente, acabará prevalecendo a resistência do solo e da rocha subjacente à erosão.

Estudando a erodibilidade dos solos do Estado de São Paulo, FREIRE e PESSOTTI (1974) concluíram que, de maneira 
geral, os Latossóis são mais resistentes à erosão do que os Solos Podzólicos, e que, dentre estes últimos, a erodibilidade au menta à medida que aumenta o gradiente textural entre os horizon tes A e B. Resultados semelhantes foram obtidos por LOMBARDI NE TO e BERTONI (1975).

Segundo STRAHLER (1957), a densidade de drenagem deve ser vista como uma expressão do espaçamento entre os canais. En geral, baixa densidade de drenagem ocorre em regiões com densa cobertura vegetativa e onde o relevo é pouco pronunciado; em outras condições ocorrerá, provavelmente, alta densidade de drenagem .

Para RAY e FISCHER (1960), as informações quantitativas obtidas de fotografias aéreas proporcionam medidas relativas ou absolutas, úteis para caracterizar formas do terre no em termos objetivos, mais consistentes do que os termos subjetivos comumente utilizados (suavemente ondulado, por exemplo), que podem levar a erros de interpretação.

Segundo GARCIA (1982), dentre os vários parâmetros foto interpretativos utilizados, a rede de drenagem assume grande des taque, uma vez que sua gênese está 1 igada a certas condições que também determinam a natureza do solo. A determinação de índices quantitativos da rede de drenagem possibilita o estabelecimento de inferências de natureza diversa e evita a subjetividade das características puramente descritivas.

STRAHLER (1964) afirmou que a densidade de drena gem, é umimportante indicador da escala linear de elementos $f i$. 
siográficos em topografia de erosão fluvial, foi introduzida na literatura hidrológica americana por Horton em 1932. A "densida de de drenagem" (D) foi definida como a razão entre o comprimen to total de rios dentro de uma bacia de drenagem e a ārea dessa bacia, sendo expressa pela equação:

$$
D=\frac{L T}{A}
$$

onde LT é o comprimento de rios e A é a área da bacia.

Ainda segundo STRAHLER (1964), Horton introduziu também o termo freqüência de rios (F), para expressar quantitativamente uma rede hidrográfica. A freqüência de rios foi definida pela equação:

$$
F=\frac{N}{A} \text {. }
$$

onde $\mathrm{N}$ é o número total de rios e $\mathrm{A}$ é a área da bacia.

Citado por STRAHLER (1964), Melton analisou deta lhadamente as relações entre densidade de drenagem e freqüência de rios, sendo que ambas medem a textura da drenagem, mas cada uma tratando de aspectos distintos. Assim, é perfeitamente possível construir duas bacias de drenagem hipotéticas, apresentan do os mesmos valores de densidade de drenagem mas com diferentes freqüências de rios; por outro lado, é possível existir duas bacias com mesma freqüência e diferentes densidades.

SMITH (1950), estudando a topografia de regiões dissecadas por rios, utilizou um indice semelhante ao da freqüência de rios de Horton, ao qual denominou razão de textura, a fim de expressar o espaçamento entre os canais de drenagem. 
Este Índice é calculado pela equação:

$$
\mathrm{T}=\frac{\mathrm{N}}{\mathrm{P}}
$$

onde $\mathrm{N}$ é o número de crênulas na curva de nível escolhida e $\mathrm{P}$ é o comprimento do perímetro da bacia, expresso em milhas. Como trabalhava com mapas topográficos, e considerando que os canais menores geralmente não são representados mesmo em bons mapas, mas apenas indicados por crênulas ou inflexões das curvas de nível, recomendou escolher a curva de nível com o maior número de crênulas, dentro da bacia de drenagem.

o mesmo autor estabeleceu um valor médio pondera do para caracterizar a textura topográfica, tomando-se em cons deração o tamanho de cada bacia. A razão de textura média pode ser determinada pela expressão:

$$
\operatorname{Tm}=\frac{\sum(\mathrm{A} \times \mathrm{T})}{\sum \mathrm{A}}
$$

onde Tm é o valor médio ponderado da razão de textura, $\mathrm{T}$ a razão de textura e A a área de cada bacia. Propôs também o estabe lecimento de limites para os valores da textura média, para classificar a textura topográfica em classes - grosseira, fina e mé dia - sendo respectivamente: menos de 4,0; entre 4,0 e 10,0; e mais de 10,0. Além disso, estudou comparativamente razão de tex tura e densidade de drenagem, concluindo que existe um relacionamento em função logarítmica entre essas características quantitativas.

Para FRANCA (1968), os sistemas de drenagem pu- 
deram ser melhor estudados em manas básicos de drenagem obtidos de fotografias aéreas, e introduziu modificações na razão de tex tura ( $\mathrm{T}$ ) e razão de textura média (Tm), considerando o valor $\mathrm{N}$ das equações como sendo o nümero total de rios da bacia, e adaptou a classificação da textura topográfica de Smith ao sistema mëtrico, transformando o perímetro em quilômetros. Os valores obtidos são: Tm menor que 2,5 km; Tm entre 2,5 e 6,2 km; e Tm maior que $6,2 \mathrm{~km}$ para as classes grosseira, média e fina, res pectivamente.

STRAHLER (1957) propôs como requisito para que duas bacias de drenagem sejam comparáveis, que elas devam ser geometricamente semelhantes. Se existir a similaridade geométri ca, todos os correspondentes nümeros adimensionais, como ângulos e razões entre medidas de comprimento, serão iguais; ainda assim existirão várias diferenças significativas entre elas.

FRANÇA (1968) aplicou os princípios da análise quantitativa de Strahler a solos e chegou às seguintes conclusões:

1) a composição e as características do padrão de drenagem variam, em primeiro lugar, com a natureza do solo e depois, com a posição topográfica e com a natureza e profundidade do substrato rochoso;

2) a análise e a interpretação do padrão de drenagem permitiram a distinção entre os solos estudados; entretan to, os outros padrões devem ser considerados;

3) a relação entre razão de textura média e densi 
dade de drenagem de amostras circulares demonstrou seroindice mais consistente e de grande utilidade na fotointerpretação de solos;

4) as características quantitativas baseadas em medições simples, exatas e reproduzíveis, podem ser utilizadas na descrição do padrão de drenagem, permitindo comparações e in terpretações mais concretas, desde que sejam superadas certas di ficuldades da amostragem ;

5) una descrição de características do padrão, por mais detalhada que seja, sempre permanecerá um tanto vaga para permitir a identificação e delimitação de solos por fotointerpretação, a não ser em trabalhos conduzidos a um nível de generalização muito grande.

RAY e FISCHER (1960) estudaram a significância da densidade de drenagem com respeito à litologia, utilizando fotografias aéreas. Os comprimentos dos rios foram relacionados com as áreas de bacias hidrográficas e amostras circulares de $10 \mathrm{~km}^{2}$. Concluíram que amostras circulares fornecem determinações de densidade de drenagem mais consistentes, para qualquer tipo de rocha, do que as amostras representadas por pequenas bacias. Quanto à significância geológica de densidade de drenagem, consideraram os dados ainda insuficientes, porém ficando claro que a permeabilidade do solo e da rocha subiacente tem influência fundamental: quanto mais alta for a permeabilidade, tanto mais baixa será a densidade de drenagem.

FRANÇA (1968) aplicou a metodologia de Ray e Fischer em estudo de solos, obtendo resultados mais significat 
vos para densidade de drenagem determinada em amostras circulares. As seguintes vantagens foram verificadas para amostras ci $\underline{r}$ culares:

1) elimina a influência da área, uma vez que todas as mediçōes de comprimento de rios são referidas à mesma àrea circular de $10 \mathrm{~km}^{2}$;

2) a área circular de amostragem pode ser deslocada, dentro da área de ocorrência de uma unidade de solo, sem consideração dos limites de bacias hidrográficas, procurando abranger unicamente a maior proporção e a maior homogeneidade pos siveis da unidade que está sendo amostrada.

O trabalho de FRANÇA (1968) foi comprovado por diversos pesquisadores como MARCHETTI (1969), FADEL (1972), VASQUES FILHO (1972), LEAO (1972), GEVAERD (1974), que estabele ceram indices caracterizando diversos solos brasileiros. Todos estes autores utilizaram o método de amostragem circular de $10 \mathrm{~km}^{2}$ apenas para densidade de drenagem. SOUZA (1975), KOFFLER (1976), FREIRE (1977), DEMÉTRIO (1977), CARVALHO (1977), SILVA (1977), NOGUEIRA (1979), POLITANO (1980), ANGULO FILHO (1981), MANECHINI (1981), VALERIO FILHO (1984), entre outros, estenderam esse método para os outros índices relacionados com área e perímetro (dens dade de drenagem, freqüência de rios, razão de textura e textura topográfica), tendo concluído que podem ser utilizados para evidenciar diferenças entre solos.

RAY e FISCHER (1960) demonstraram que as medidas de densidade de drenagem podem tornar-se inconsistentes se forem 
comparadas fotografias de escalas diferentes. Isto se deve à per da gradativa na habilidade de se detectar pequenos cursos d'ägua quando a escala torna-se meno $r$. Observaram que a relação entre a variação da escala e a diminuição na densidade de drenagem é uma função linear, sugerindo que um simples fator de conversão pode permitir a determinação da densidade de drenagem a partir de diferentes escalas.

KOFFLER (1976a), utilizando imagens aerofotográficas (escalas 1:25.000 e 1:60.000) e orbitais (SKYLAB e LANDSAT-1) no estudo de padrões de drenagem de três tipos de solos, verifi cou que os resultados concordaram com os estudos obtidos por SOUZA (1975). Concluiu que em imagens do LANDSAT outros padrões de interpretação convencional podem assumir maior importância, como feições tonais e texturais; e que as características dos padrões de drenagem foram condicionadas, principalmente, pèla natureza e propriedade dos solos, existindo uma tendência de aproximação dos valores de cada característica quantitativa, reduzindo a separabilidade dos três tipos de solo, à medida que a escala das fotografias diminui.

Ainda KOFFLER (1976b), utilizando-se de amostras circulares com áreas que variam de 10 a $100 \mathrm{~km}^{2}$, como sugeriu BURINGH (1960), sobre fotografias aéreas verticais de escala 1:60.000, analisou o efeito do tamanho da amostra na caracterização quantitativa de um padrão de drenagem e a sua comparação com outros, podendo ser efetuadas através dos índices de densidade de drenagem, freqüência de rios e comprimento médio dos ca 
nais, independentemente do tamanho das amostras circulares, des de que sejam representativas.

DEMETRIO (1977), trabalhando com solos do Municí pio de Piracicaba, sobre fotografias aéreas, utilizou-se de amostras circulares com äreas de $3 \mathrm{~km}^{2}, 10 \mathrm{~km}^{2}$ e $20 \mathrm{~km}^{2}$, respectivamente, para fotografias aéreas de escalas 1:8.000, 1:25.000 e $1: 60.000$; e concluiu que o sistema de amostragem circular mos trou-se eficiente e prático para a análise quantitativa do padrão de drenagem nas três escalas de fotografias aéreas conside radas. Este autor concluiu que existe uma tendência de aproxima ção dos valores das características quantitativas. à medida que a escala das fotografias diminui, mas a densidade de drenagem, freqüência de rios e razão de textura, diferem entre si nas escalas extremas, ou seja, 1:8.000 e 1:60.000.

\subsection{CARACTERISTICAS DO RELEVO RELACIONADAS A SOLOS}

Para BELCHER (1945), os principais elementos indicadores das diferenças em solos e formações geológicas, obtidos em fotografias aêreas são : 1) geologia; 2) declividade; 3) drenagem superficial; 4) cor e tonalidade dos solos; 5) cobertura vegetal; 6) erosão; e 7) uso da terra.

Segundo AVERY (1977), os fatores mais importan tes a serem considerados na evolução da paisagem, associados aos solos são: 1) topografia; 2) padrões de drenagem; 3) erosão 1o cal; 4) vegetação natural; e 5) trabalho do homem. 
Os aspectos do relevo influem de forma direta na evolução do perfil de solo e vice-versa; portanto, ao interpretar a evolução das formas do relevo pode dizer-se que, ao mesmo tempo, se está interpretando a evolução do corpo dos solos em conjunto, afirmou MONTOYA (1983).

Conforme citação de VIEIRA (1975), o relevo ou to pografia que denota a configuração da superfície da Terra, é um importante fator no processo evolutivo do solo. A sua influência na formação do solo e no desenvolvimento do perfil é marcante. Dokuchaev, eminente geólogo russo, um dos iniciadores da pedolo gia moderna, foi quem atribuiu importância, pela primeira vez, ao estabelecer correlação entre o solo e o relevo. Segundo ele, a topografia poderia modificar o perfil do solo de três maneiras:

a) facilitando a absorção e retenção de água de precipitação, pelo solo - relação de umidade;

b) influenciando no grau de remoção de partículas do solo pela erosão; e

c) facilitando a movimentação do material em sus pensão ou em solução, para outras áreas.

Segundo GOOSEN (1968), o relevo desempenha um importante papel na determinação da natureza e amplitude dos dis tintos processos que formam o solo, tais como: erosão e drenagem. Para CHRISTOFOLETTI (1969), a movimentação do relevotambëm age como fator importante na densidade, dedrenagem pois as áreas de relevo mais movimentado possuem trama mais densa dos 
canais, que nas áreas de relevo suave.

Ainda CHRISTOFOLETTI (1980) atestou que um aumen to nos valores de declividade do terreno, provoca um aumento nos valores de textura topográfica e densidade de drenagem.

Diversos autores, entre os quais HORTON (1945), SMITH (1950) e STRAHLER (1957), têm demonstrado que existem for tes relacionamentos entre as características da rede de drena- gem e as condições topográficas, e que, muitas vezes, variações no comportamento da drenagem refletem alterações das condições topográficas de uma região.

Para RAY (1963), cada padrão de relevo está asso ciado com um processo geomórfico específico de erosão ou deposi ção e reflete a origem e o carāter geral da paisagem; e que a e volução das feições topográficas do relevo, associadas com os processos de erosão e deposição, também propiciam uma base excelente para uma estratificação da paisagem pela origem das suas formas e tipos de material superficial.

Segundo ȘMITH e AANDAHL (1957), as unidades de solo não ocorrem ao acaso na paisagem; elas possuem um padrão de distribuição que está relacionado à forma do terreno, ao material de origem do qual o solo se formou, a influência das plan tas que nele vivem e da maneira pela qual o homem o tem utiliza do. Geralmente as diferentes unidades de solo têm um padrão de distribuição que se repete, o qual está associado com o relevo. Para AMARAL e AUDI (1972), sendo o relevo um dos principais agentes formadores do solo, deve-se esperar com sua 
variação, diferenças nos solos. A recíproca, porém, não é verda deira, pois o solo pode variar, mesmo sem variar o relevo, deví do a possíveis variações nos demais fatores de formação do solo. No trabalho de SILVA (1977), o autor atribuiu ao relevo, em primeiro lugar, e ao controle geológico, em seguida, - grau de desenvolvimento das redes de drenagem, através da alteração da relação infiltração/deflúvio.

Para ANGULO FILHO (1981), as características do padrão de drenagem foram condicionadas pela natureza e propriedades dos solos estudados, pela natureza e profundidade do subs trato rochoso, posição que ocupam no relevo regional e, também, pela vegetação e uso da terra em cada período considerado, modi ficando as características de drenagem.

BRIDGES e DOORNKAMP (1963), analisando comparati vamente o mapa de superfícies morfológicas com o mapa de solos, concluíram que, na maior parte da área estudada, as quebras e mudanças do relevo coincidem com os limites de grupos de solos; onde mudanças menores do relevo coincidem com mudanças do material de origem, eles também coincidem com os limites de solos. HILWIG e KARALE (1973) constataram que tanto os elementos do relevo como das vertentes são caracterizados por $\underline{u}$ ma alta relação com as condições de solo e uma alta coincidência. com os limites dos solos. Concluíram que o mapeamento de solos baseado em análise fisiográfica de documentos fotográficos, mos tra unidades de mapeamento que consistem de unidades taxonômicas simples, nos quais o arranjo tridimensional e geográfico dos so 
los está claramente expresso.

Segundo CHRISTOFOLETTI (1980), quanto maior a densidade de drenagem em uma ärea com relevo semelhante, menores e mais inclinadas serão as vertentes.

o relevo é considerado como um dos critérios mais importantes da fotopedologia, sendo muito utilizado para estudos de solos em fotografias aéreas convencionais por apresentarem a vantagem da observação da terceira dimensão, através do emprego de pares estereoscópicos, segundo citação de ROURKE e AUSTIN (1951), LUEDER (1959), SOIL CONSERVATION SERVICE (1966), AMARAL e AUDI (1972).

Para AVERBECK e SANTOS (1969), a variação na declivida de geralmente implica em variação do solo. O relevo, a declividade e as formas de erosão resultam, na fotografia aérea, em di ferenças no padrão e na textura fotogräfica.

ROURKE e AUSTIN (1951) consideraram que a diferença de declividade das encostas determina a variação na quantidade de energia refletida, provocando modificações na tonalidade, em função da maior ou menor declividade do terreno.

CURTIS et alii (1.965) propuseram uma classificação do relevo para fins de estudos de solo, baseada nos itens que caracterizam a paisagem, como: aspecto local e altitude relativa da região.

Vadnais, citado por WONG et alii (1977), analisando a contribuição dos fatores do relevo na classificação de associações de solos, utilizou amostras circulares para quanti- 
ficação de 16 fatores do terreno dentre eles a declividade média, relevo local, índice de rugosidade e número médio de vertentes e encontrou combinações positivas destes fatores com as associações de solos estudadas.

WONG et alii (1977) utilizaram cartas topográficas para a realização de medidas quantitativas dos fatores de relevo (declividade média, relevo amostral, relação relevo/elevação), através de amostras quadradas para estudos de diferen ciação de solos, sendo que o método de Wentworth para cálculo da declividade mostrou-se de grande eficiência. KOFFLER (1982) também utilizou o método de Wentworth para cálculo de declivida de média do terreno e recomenda este em vez do STRAHLER (1956), por ser de mais fácil aplicação e por apresentar resultados se melhantes.

MARCHETTI (1969) concluiu que os índices de rele vo, declive máximo da encosta e razão de decuive, mostraram-se dignos de confiança para a distinção entre solos.

Para VALERIO FILHO (1984) os índices de relevo (declividade média, relevo local médio e comprimento médio da vertente) foram mais eficazes que os indices de drenagem na dis criminação dos solos, sendo que os dois primeiros índices demonstraram maior eficácia que o comprimento médio da vertente.

Analisando índices de relevo na diferenciação de solos com B latossólico e B textural, LEÃO (1983) encontrou resultados positivos para os índices amplitude altimétrica e razão de relevo, evidenciando assim, aptidão destes índices para 
a distinção dos solos estudados.

Peltier, citado por WONG et alii (1977), após analisar a declividade média através de 70 cartas topogräficas pelo método de Wentworth, concluju que a declividade média esta va relacionada com a média local do relevo e a textura mëdia da topografia.

POLITANO (1980) concluiu que os indices de relevo foram tão eficazes quanto os da rede de drenagem, para a diferenciação de duas classes de Solos Podzólicos Vermelho-Amare1os.

\subsection{VERIFICACÃO DA PRECISÃO DAS CARTAS PLANIALTIMÉTRICAS}

Segundo HENRIKSEN (1980), a precisão vertical é verificada sobre cada projeto com o número de pontos-testes determinado pelo tamanho do projeto, mas deve ser no mínimo 20 . Um maior número de testẹs é feito em äreas de relevo suave, onde os intervalos de contorno (curvas) são maiores. As elevações no campo são obtidas por estádia transversal, nivelamento trigo nométrico ou níveis de precisão, e deve ter a precisão de $10 \%$ do intervalo de contorno. De acordo com o "National. Map Accuracy Standards" dos EUA, no projeto, 90\% das elevações testadas sobre o mapa devem coincidir com as elevações de campo dentro de metade do intervalo de contorno. Na determinação da precisão vertical, o erro vertical aparente pode ser diminuido assumindo-se um deslo 
camento horizontal dentro de um erro horizontal permissível para um mapa na escala que está sendo testada.

ANGULO FILHO et alii (1983), concluiram que a de limitação das classes de declịve serve de parâmetro para a veri ficação da aproximação entre a carta obtida por restituição aerofotogramétrica e a carta obtida por métodos de campo. A análi se estatística acusou, para a maior parte dos casos, direrenças significativas entre ambas as cartas estudadas, sendo majs acen tuadas em superfícies topograficamente homogêneas, por não haver termo de comparação no modelo estereoscópico quando restituído. DEMETRIO (1984) confirmou estas observaçôes, concluindo que o deslocamento horizontal das curvas de nível restituídas é mais evidenciado em regiões de relevo suave e uniforme, pois di ficulta a percepção estereoscópica. 


\title{
3. MATERIAL E MÉTODOS
}

\author{
3.1. MATERIAL
}

\subsubsection{DESCRICÃO E LOCALIZACÃO DAS ÁREAS DE ESTUDO}

\subsubsection{Localização geogrắfica}

A primeira ärea de estudo, de onde foram retiradas as amostras circulares correspondentes ao latossolo VermelhoAmarelo e Podzólico Vermelho-Amarelo, segundo OLIVEIRA et alii (1982) e que passarâa a ser denominada de Área A, encontra-se entre os paralelos $22^{\circ} 00^{\prime} \mathrm{S}$ e $22^{\circ} 30^{\prime} \mathrm{S}$ e os meridianos $47^{\circ} 00^{\prime} \mathrm{IWG}$ e $47^{\circ} 30^{\prime} \mathrm{WG}$, abrangendo total ou parcialmente os seguintes municípios, como mostra a Figura 1: Aguai, Araras, Artur Nogueira, Casa Branca, Conchal, Cordeirópolis, Corumbataí, Leme, Limeira, Moji-Guaçu, Moji-Mirim, Pirassununga, Rio Claro, Santa Cruz da Conceição e Santa Gertrudes. 
Esta ârea situa-se no centro-oeste do Estado de São Paulo, inteiramente inserida na Depressão Perifêrica e na sua quase totalidade na Zona do Mẻdio Tiête.

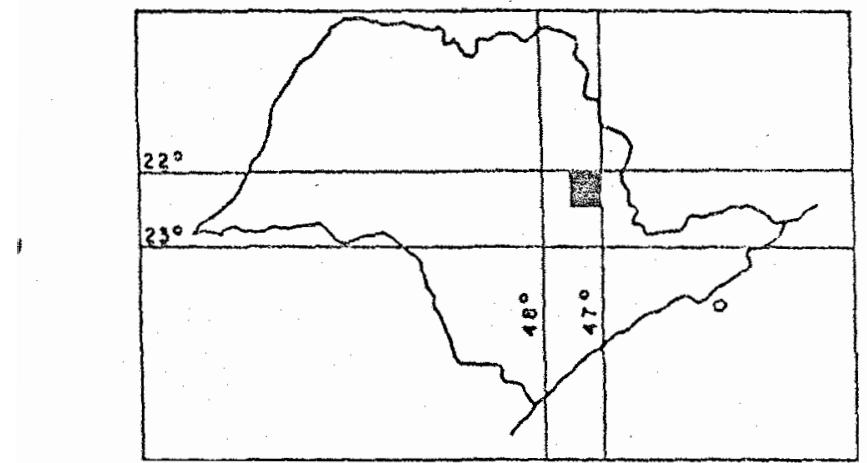

Losalização da área estudada no Estado de São Paulo

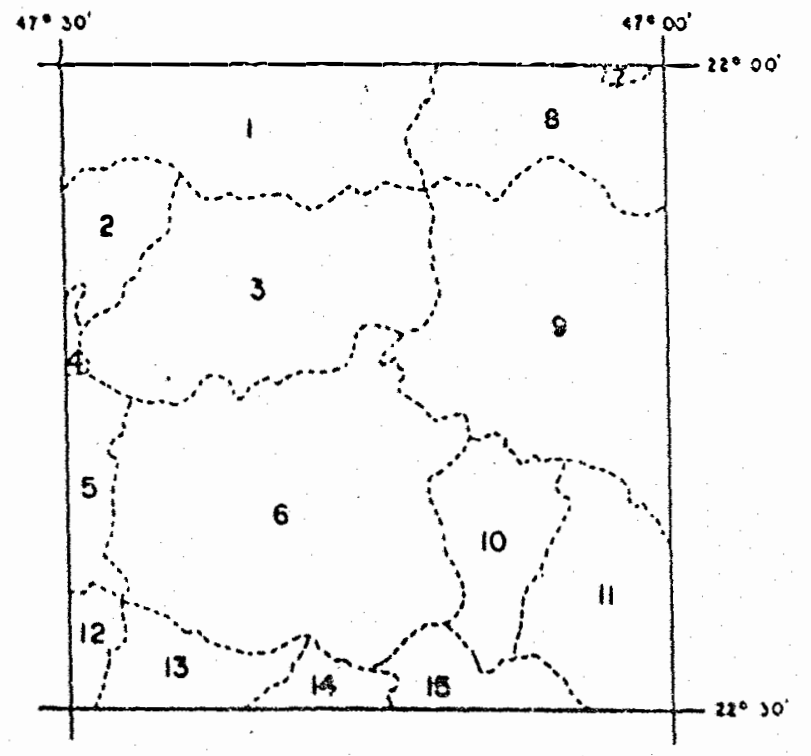

$\begin{array}{lll}1 \text { - Piraçununga } & 6 \text { - Araras } & 11 \text { - Moji-Mirim } \\ 2 \text { - Santa Cruz da Conceiçto } & 7 \text { - Casa Branca } & 12 \text { - Santa Gertrudes } \\ 3 \text { - Leme } & 8 \text { - Aguai } & 13 \text { - Cordeirópolis } \\ 4 \text { - Corumbatal } & 9 \text { - Moji-Guaçu } & 14 \text { - Limeira } \\ 5 \text { - Rio Claro } & 10 \text { - Conchal } & 15 \text { - Artur Nogueira }\end{array}$

- Figura 1 - Localização da ārea de onde foram retiradas as amostras circulares de Latossolo Vermelho-Amarelo e Podzólico Vermelho-Amare 10. 


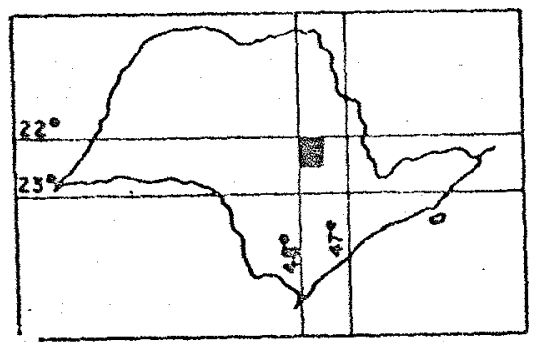

Localiza ção da quadrícula de São Carlos no estado Je Sān Paulo.

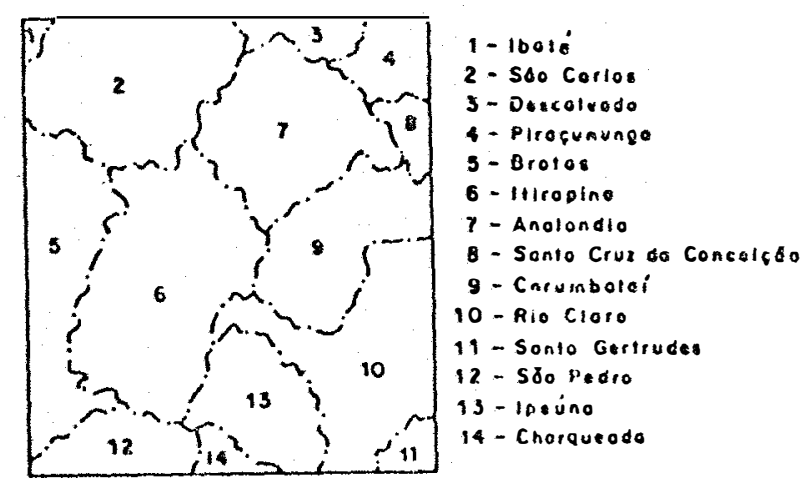

Figura 2 - Localização da ārea de onde foram retiradas as amostras circulares de Litossolo.

A outra área de estudo, de onde foram retiradas as amostras circulares de Litossolo segundo OLIVEIRA e PRADO (1984), e que doravente serā denominada de Area B, estā compreendida, entre os paraleros $22^{\circ} 00^{\prime} \mathrm{S}$ e $22^{\circ} 30^{\prime} \mathrm{S}$ e os meridianos $47^{\circ} 30^{\prime} \mathrm{WG}$ e $48^{\circ} 00^{\prime} W G$, abrangendo total ou parcialmente os seguintes municípios como mostra a Figura 2: Analândia, Brotas, Charqueada, Corumbataí, Descalvado, Ibati, Ipeúna, Itirapina, Pirassununga, Rio Claro, Santa Cruz da Conceição, Santa Gertrudes, São Carlos e São Pedro.

Estas äreas, segundo ALMEIDA (1964), encontram- 
se nas regiões denominadas de Depressão Periférica (Sub-região médio Tietê) e "Cuestas" Basälticas.

\section{1 .1 .2 . Relevo}

A topografia da Area A caracteriza-se por apresentar, segundo OLIVEIRA et alii (1982), em cerca de $85^{\circ}$ da área uma sucessão de baixas colinas de formas suavizadas e com topos subaplainados, ligeiramente abaulados, mantidos geralmen te nas cotas 580-680 metros, com relevo suave a suave ondulado e declives que, na sua maior parte, raramente atingem $5 \%$ e menos de 3\% nos topos; este relevo caracteriza a área de Latosso'1o Verme1ho-Amare1o.

O solo Podzólico Vermelho-Amarẹlo encontra-se nu ma faixa de 8 a $10 \mathrm{~km}$ de largura que se estende desde pirassununga até Leme, onde o relevo se torna mais movimentado. Os cór regos que drenam para o ribeirão do Arouca, correndo sobre sedimentos do permo-carbonífero, imprimiram maior densidade à rede de drenagem e maior vigor aos entalhes. Aí o relevo é tipicamen te suave ondulado dissecado ou ondulado dissecado com declives da ordem de 7 a $15 \%$ nas partes baixa e média das vertentes. Os topos das colinas, contudo, apresentam-se esbatidos, com declives inferiores a $5 \%$.

Da área $B$ o relevo que interessa é aquele onde se encontra o Litossolo; e segundo OLIVEIRA e PRADO (1984), es- 
te relevo se caracteriza por ser intensamente dissecado pelos seguintes cursos d'água: rio Passa Cinco, rio Corumbataí e Ribeirão Claro; geralmente abaixo da cota 630 metros; quando eles atingem os sedimentos da formação Corumbataí, o relevo torna-se mais movimentado, - com aumento da declividade das vertentes, que, em algumas áreas, chegam a ultrapassar $12 \%$. Ocorrem nessas ver tentes os Litossolos substrato sedimentos finos do permo-carbo-nífero (Li1) e os Podzólicos Vermelho-Amarelos das unidades San ta Cruz (PV1) e Olaria (PV6).

\section{$3 \cdot 1 \cdot 1.3 \cdot$ Geologia}

De acordo com o "Mapa Geológico do Estado de São Paulo", quadrícula de Campinas, elaborado pelo convênio entre DAEE e UNESP, em 1982, verificou-se que nas duas áreas de estudo encontram-se as mesmas formações geológicas e que são as seguintes:

a) Plioceno-Pleistoceno: depósitos coluviais e Formação Rio Claro;

b) Oligoceno - Mioceno: depósitos de cimeira;

c) Triássico - Cretáceo (Grupo São Bento): Forma ção Serra Geral, Formação Botucatu e Formação Pirambóia;

d) Permiano (Grupo Passa Dois): Formação Corumba taí e Formação Iratí,

e) Carbonífero - Permiano (Grupo Tubarão); Forma 
ção Tatuí, Formação Aquidauana e Formação Itararé.

Dentre todas as formações geológicas citadas, se rão descritas a seguir aquelas que predominam nas äreas onde fo ram retiradas, respectivamente, as amostras circulares de Latos solo Vermelho-Amarelo, Podzólico Vermelho-Amarelo e Litossolo.

- Formação Aquidauana:

Segundo SCHOBBENHAUS et alii (1984), a denominação dada a essa unidade deve-se a Lisboa (1909), que realizou estudos ao longo da Estrada de Ferro Noroeste do Brasil, no Mato Grosso do Sul. Almeida $(1948,1954)$ redescreveu a formação Aquidauana como sendo um pacote de arenitos com cimento fer ruginoso, folhelhos vermelho, conglomerados e níveis de tilito. Ocorre na borda ocidental da bacia do Paraná, em Mato Gros so, Goiás e Mato Grosso do Sul;

- Formação Itararé:

Para SCHOBBENHAUS et alii (1984), a formação Ita raré apresenta grande diversidade litológica, predominando, no entanto, os clästicos grossos que ocorrem em toda a seção. As variações laterais de fácies são uma das características mais marcantes desse pacote sedimentar. Diamictitos passam lateral mente para folhelhos várvicos, ritmitos e arenitos.

Em São Paulo, a seqüência é constituída de sedimentos arenosos com diamictitos caracterizados pela cor vermelho tijolo. Os arenitos mostram granulometria desde grossa a muito fina, com abundante matriz argilosa, com estratificação cruzada 
planar, de pequeno e médio porte. Os diamictitos contêm seixos e matacões, os quais diminuem em direção ao topo, passando para lamitos arenosos e silltico-argilosos. Segundo Andrade e Soares (1971), esta seqüência começa a ocorrer a partir do Rio MojiGuaçu, em direção ao norte. Ao sul do rio Piracicaba desaparecem as características vermelhas da seqüencia e dominam os clásticos grosseiros, arenitos, conglomerados e diamictitos, com desen volvimento subordinado de siltitos. Normalmente, apresentam es tratificação plano-paralela e cruzada do tipo planar e acanala$\mathrm{da}$;

- Depósitos coluviais:

Formação do período Plioceno...Pleistoceno, caracteriza-se por depósitos coluviais de espigão, areias com matriz argilosa, cascalhos de limonita e quartzo na base;

- Formação Corumbataí:

Segundo SCHOBBENHAUS et alii (1984), a designação Corumbataí é adotada nos estados de Goiảs, Mato Grosso, São Paulo e parte do Paraná, para indicar a seção compreendida desde o topo da Irati até a base da Pirambóia. Florance e Pacheco (1929) verificaram que, nestes estados, a parte superior da for mação Corumbataí corresponde em parte, à formação Rio do Rasto. Sua espessura, em superfície, atinge valores da ordem de $250 \mathrm{~m}$.

Á formação Corumbataí caracteriza-se por possuir arenitos muito finos, siltitos, lamitos e folhelhos, níveis de calcários oolíticos e coquina e cores lilás e cinza indicam am- 
biente deposicional oxidante;

- Formação Pirambóia:

A formação Pirambóia caracteriza-se, segundo SCHOBBENHAUS et alii (1984), pela ocorrência de arenitos esbran quiçados, amarelados e avermelhados, médios a muito finos, síltico-argilosos, grãos polidos, subangulares e subarredondados com seixos de argila. Na porção mais inferior da formação Pirañ bóia ocorre uma camada de 1 a $2 \mathrm{~m}$ de espessura, de cor avermelhada, areno-argilosa, com seixos de silex; ocorrem também intercalações de siltitos e folhelhos nos arenitos pirambóia coin espessuras variando de alguns milímctros até $1 \mathrm{~m}$. Estratificação plano paralela é freqüente nos arenitos Piramböià.

A formação Pirambóia distribui-se de maneira con tínua nos estados de São Paulo, Goiás, Mato Grosso e nordeste do Paraná, näo tendo sido identificada nos estados do Rio Grande do Sul e Santa Catarina.

\subsubsection{C1ima}

A Tabela 1 apresenta os dados de temperatura média e precipitação pluvial mensal de quatro localidades ảa Area A, enquanto a Figura 3 apresenta os balanços hídricos correspon dentes, calculados segundo método de "Thornthwaite e Mather - 1955 ".

Observa-se pelos dados, que a distribuição pluvial segue o regime típico das zonas tropicais de baixa altitu- 
de, ou seja, verão chuvoso e inverno seco. O regime térmico do ar, por sua vez, acompanha de perto as estações do ano, variando gradativamente com elas. As médias do inverno chegam em junho e julho a valores inferiores a $18^{\circ} \mathrm{C}$, superando $22^{\circ} \mathrm{C}$ em janeiro e fevereiro.

Os dados de temperatura e precipitação apresenta dos permitem identificar, segundo o sistema de Köppen, um clima - do tipo Cwa, ou seja, clima nesotérmico de inverno seco.

Segundo OlIVEIRA et alii (1975), os regimes hídrico, e térmico dessa região são, respectivamente, o üdico é o hipertérmico.

Para a Ärea B, os dados de temperatura média e precipitação mensal encontram-se na Tabela 2 , enquanto a Figura 4 apresenta os diagramas dos balanços hídricos correspondentes, calculados segundo método de "Thorthwaite e Mather" - 1955.

Observa-se pelos dados que a distribuição das chuvas é semelhante para as quatro localidades, ocorrendo um pe ríodo chuvoso, que se estende de outubro a março, e outro seco, de abril a setembro. A passagem de um período para outro se $d \vec{a}$ abruptamente.

O regime térmico, por sua vez, acompanha de per to as estações do ano, variando gradativamente com elas.

Estes dados de precipitação e temperatura permi tem identificar dois tipos de clima, segundo o sistema de Köppen: para São Carlos e áreas serranas, um clima Câb, ou seja, tempera do com inverno seco e temperatura do mês mais quente inferior a 

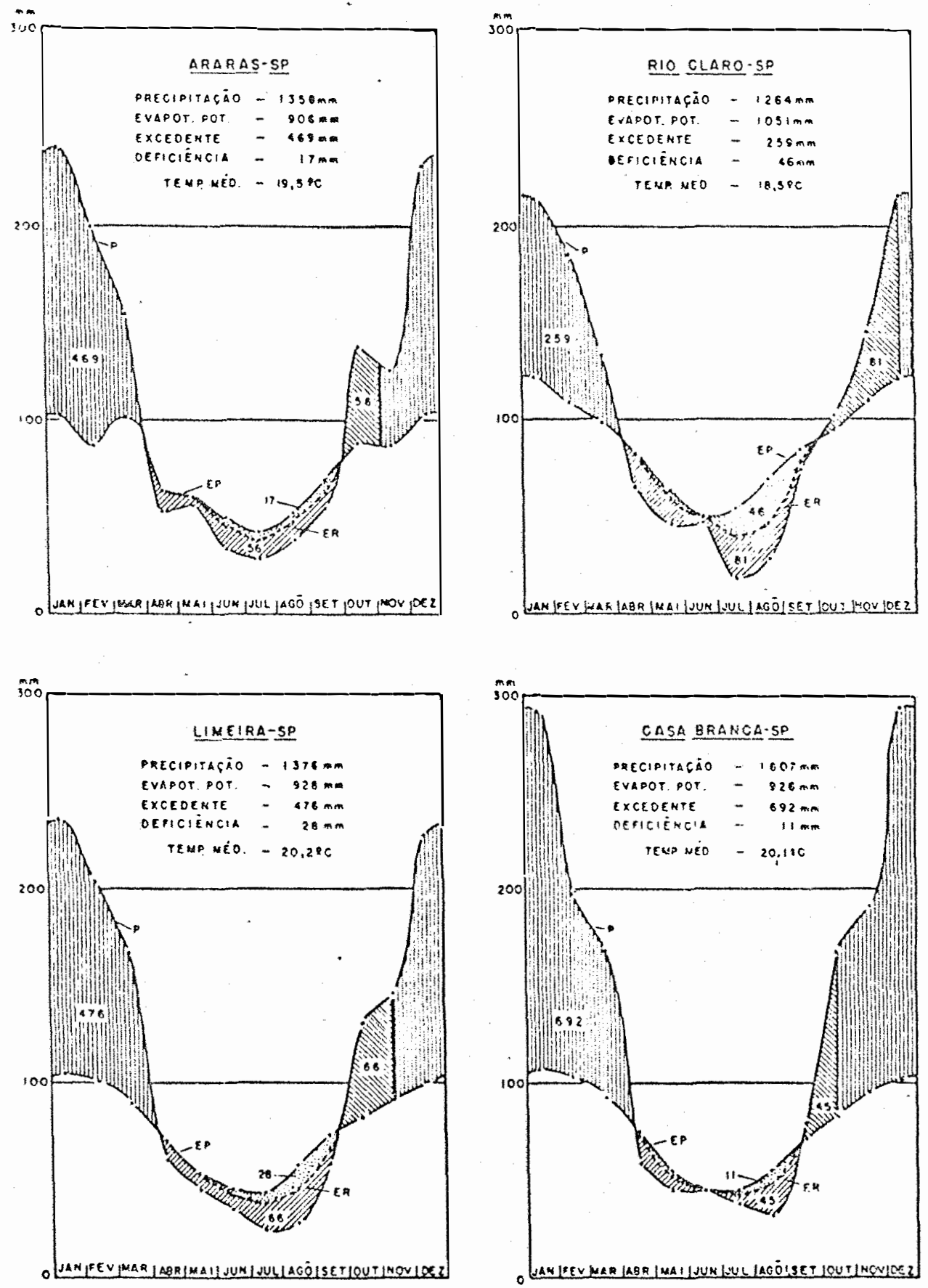

Figura 3 - Balanço hídrico segundo mëtodo de "Thornthwaite e Mather - 1955" para quatro localidades da Area A. (Fonte: OLIVEIRA et alii, 1982) 
.42 .

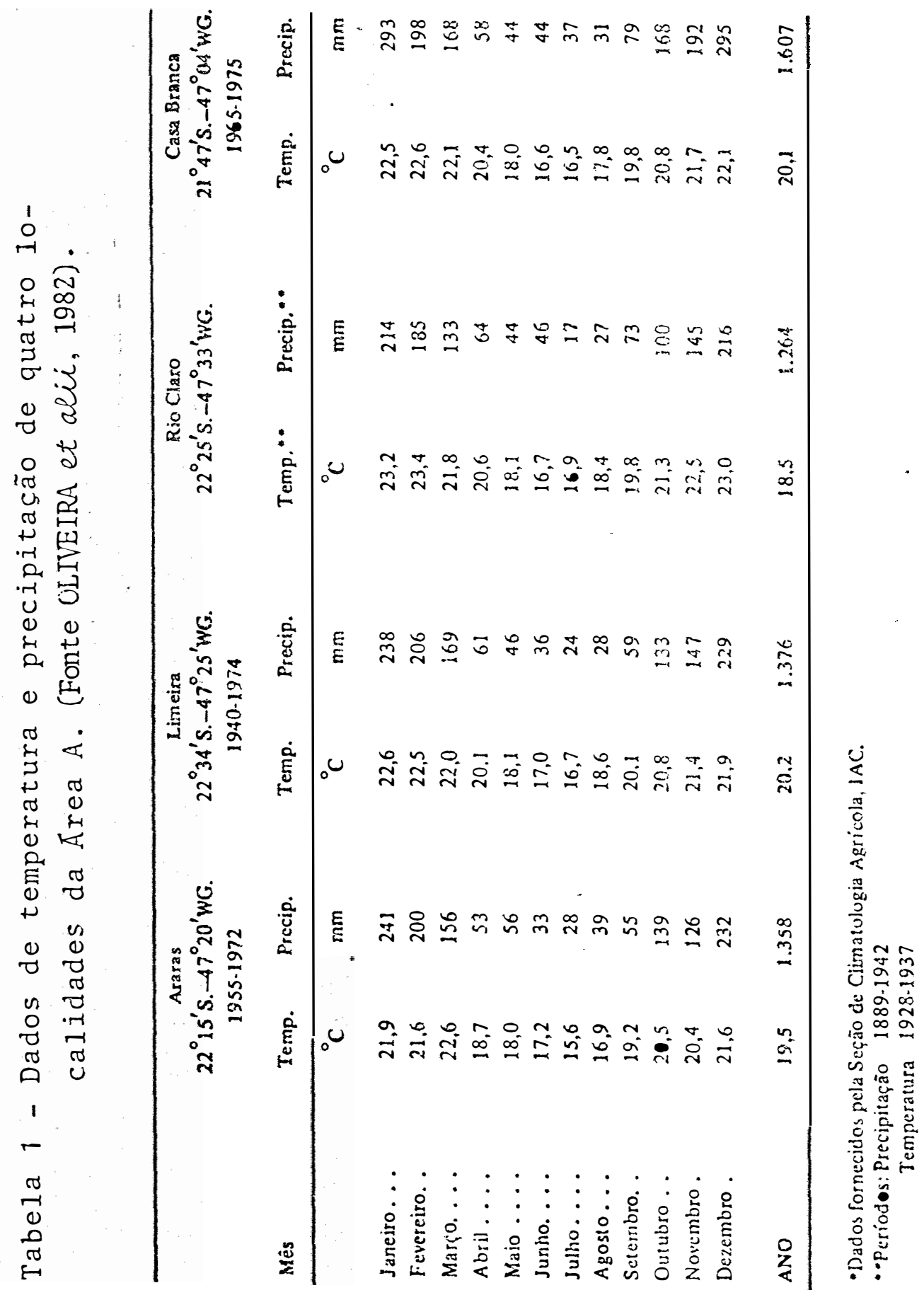


$22^{\circ} \mathrm{C}$. Para as demais, cujas temperaturas do mes mals quente sao superiores a $22^{\circ} \mathrm{C}$, o clima, ainda temperado, é Cwa.

Segundo OLIVEIRA et alii (1375), os regimes hídricos e térmicos dessa região são, respectivamente, o údico e o hipertérmico, nas áreas inferiores a 1000 metros, e o térmico, nas mais elevadas.

3.1.1.5. Vegetação primitiva e uso atual da terra

Na Ārea A nota-se, segundo OLIVEJRA et alii (1982), uma correspondência estreita entre a qualidade do solo e seu a proveitamento. Nos solos de textura argilosa provenientes de ma teriais oriundos de rochas básicas e sedimentos do permo-carbo nífero, a vegetação original, a julgar pelos reduzidos remanescentes, era representada nrincinalmente nela mata subpercnifólia. Essa vegetação, contudo, praticamente inexiste, substituída que foi, em decorrência do relevo pouco movimentado e da qualidade das terras, por agricultura representada, em ordem de importancia espacial, pela cana-de-açucar, citros, algodão, café e, em menor proporção, por culturas anuais.

Nas areas onde predominam os solos arenosos ou de textura média, apesar do relevo suave ondulado, persiste a maior reserva de vegetação natural da região representada por cerrados e cerradões, em parte preservados devido às limitações impostas pelos solos e, em parte, por se encontrarem em reservas ecológ $\underline{i}$ 
.44.
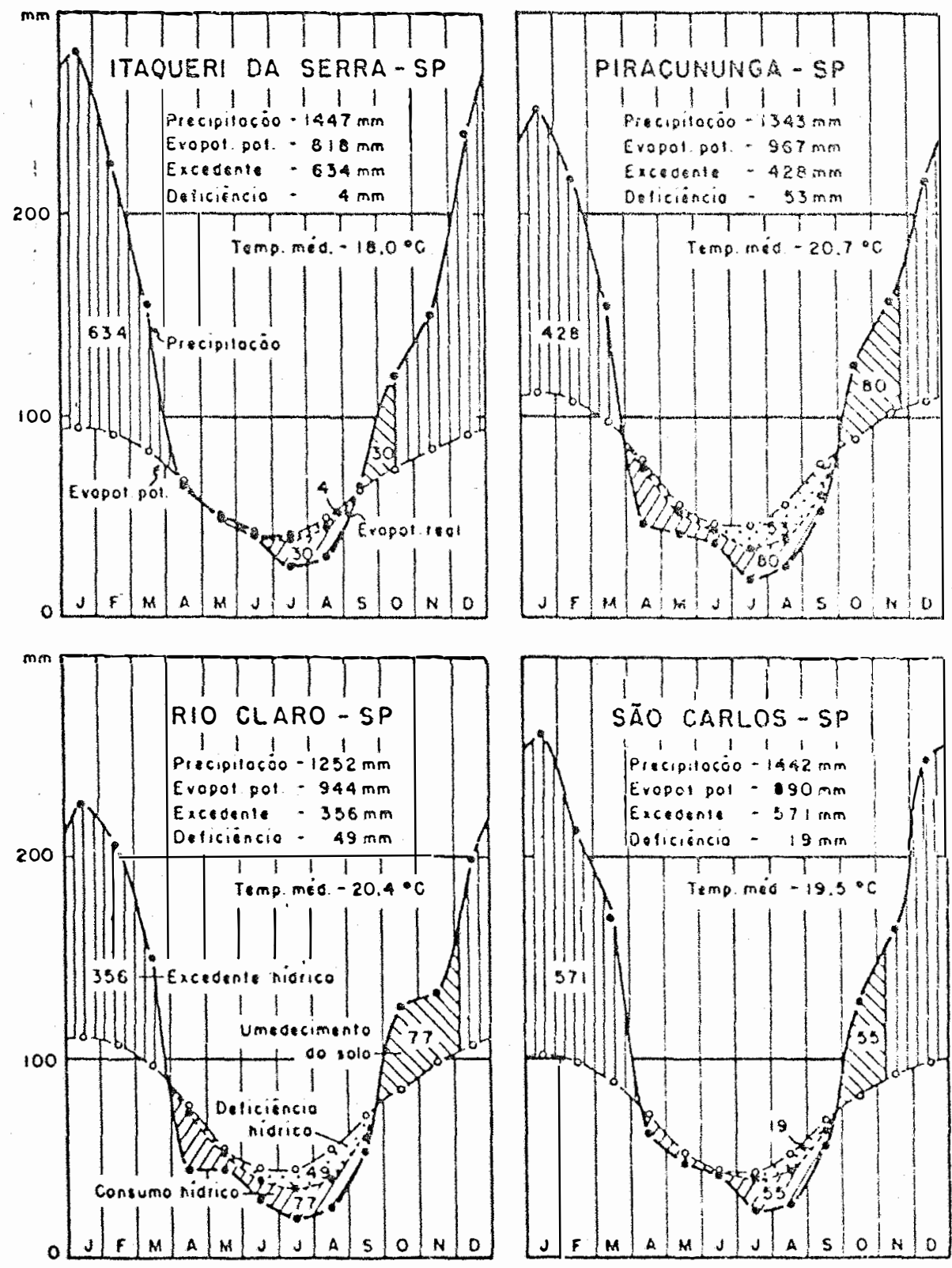

Figura 4 - Balanço hídrico sepundo método de "Thornthwaite e Mather - 1955" para quatro localidades da Area B. (Fonte: OLIVEIRA e PRADO,1984) 


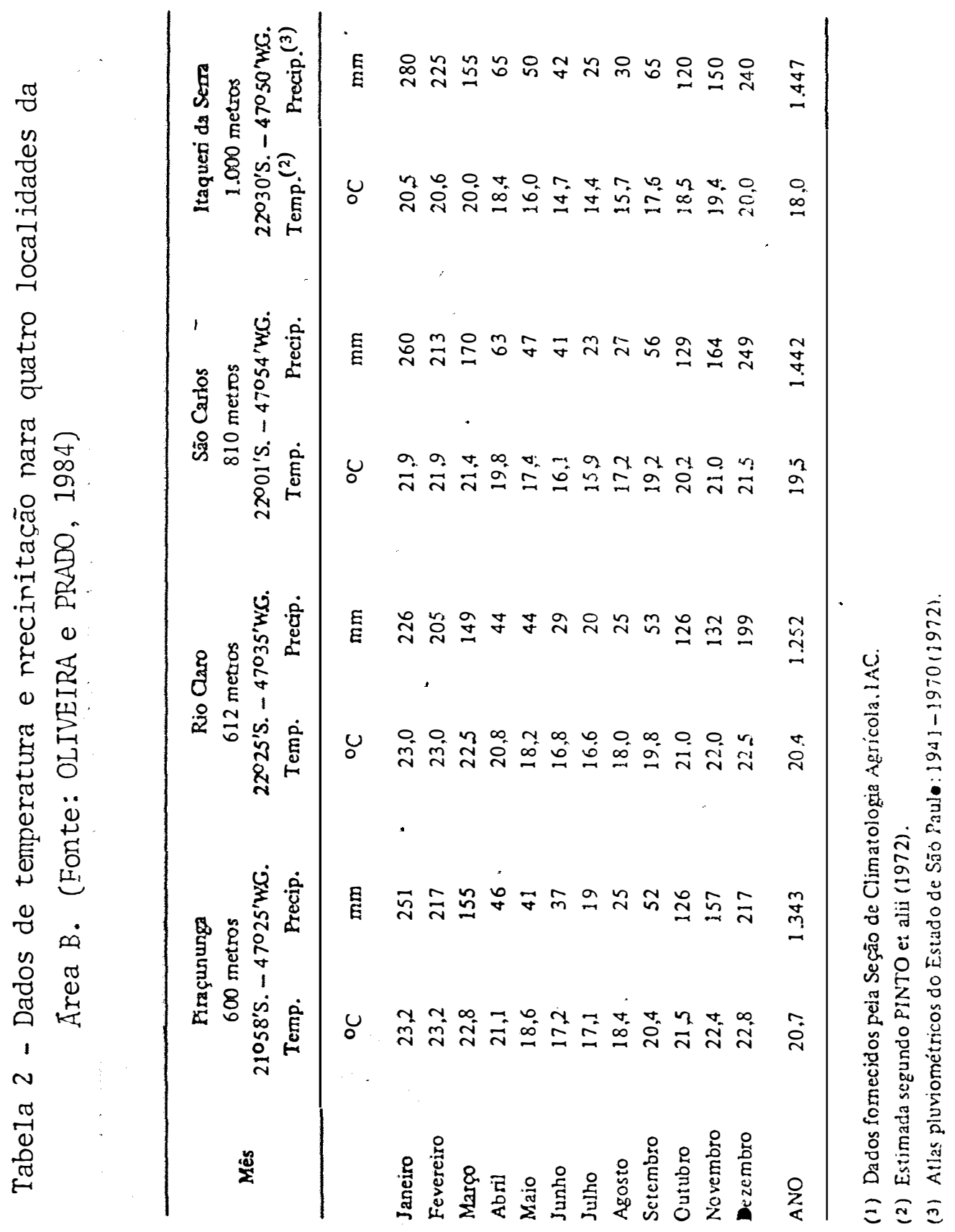


cas estaduais. A agricultura é representada especialmente por citros e cana-de-açucar que, progressivamente vai invadindo tam bém essas āreas, porém o reflorestamento é o seu principal uso. Nas partes úmidas, representadas pelas planícies aluvionais mal drenadas, ocorrem vegetações de campo higrófilas, enquanto nas áreas melhor drenadas próximo à calha dos rios pre dominava a mata ciliar, agora restrita a uma estreita faixa des contínua às margens do Moji-Guaçu.

Da mesma forma que na Ârea A, a distribuição da vegetação natural da Area B, segundo OLIVEIRA e PRADO (1984), a presenta estreita relação com a composição granulométrica, espessura e classe de solos.

Como conseqüência da predominância de solos mui.. to profundos, excessivamente drenados ou muito permeäveis e de baixo potencial nutricional, a vegetação primitiva mais comun $\underline{e}$ ra representada pelos campos cerrados, cerrados e ccrradões. Es tes, não obstante o contínuo avanço da cultura canavieira, ainda persistem, em extensas áreas contínuas nos planaltos deprimi dos da serra de Santana e de Campo Alegre e em manchas menores esparsas, remanescentes da crescente ocupação do solo com reflo restamentos, culturas de citros e de cana-de-açucar, principalmente.

Observa-se que hā maior predominância de cerrados nos solos de textura mais grossa: areias quartzosas profun das e latossolos de textura média, enquanto os cerradões predominam nos solos de textura relativamente mais argilosa. 
Nos solos profundos, de textura argilosa, a vege tação primária predominante era a mata tropical subcaducifólia, da qual restam apenas esparsos e reduzidos testemunhos. Em äreas de 1itossolos substrato basalto, onde o declive acentuado facilita o escoamento superficial da chuva, a menor reserva de âgua influencia também o tipo de vegetação, que nestas condições correspondemas matas decíduas de aspecto mais seco que as encontradas em solos profundos e menos declivosos.

Ao longo das margens de alguns cursos d'água, aparecem matas ciliares, enquanto nas planícies de inundação do ribeirão do Lobo, rio Itaqueri e ribeirão do Feijão, predominam campos higrófilos.

Por essa região fazer parte de importante bacia leiteira, as pastagens ocupam expressiva área, preferencialmente de solos pobres e de textura arenosa. O reflorestamento também ocorre em extensas áreas de solos arenosos e pobres. A exploração de cana-de-açucar, café e milho desenvolveu-se em solos de melhores propriedades físicas e químicas, além da facili dade para a mecanização; entretanto, nota-se acentuada expansão da cultura canavieira, invadindo áreas de pastagens e de cerrados.

\subsubsection{Solos}

Do exame das cartas de solos do levantamento pe- 
dológico semi-detalhado do Estado de São Paulo, quadrículas de Araras e São Carlos (āreas A e B), realizadas respectivamente por OLIVEIRA et alii (1982) e OLIVEIRA e PRADO (1984), constatou-se a presença dos seguintes solos: Latossolo Roxo; Latossolo Vermelho Escuro; Latossolo Vermelho-Amarelo; Podzólico VermelhoAmare1o; Terra Roxa Estruturada; Areias Quartzosas Profundas; Litossoles; Solos Hidromórficos; Cambissolos e Solos Concrecionários. Entretanto, devido à posição topográfica e o tamanho da unidade de mapeamento pedológico, que permitisse retirar as amostras circulares de $10 \mathrm{~km}^{2}$, que eram de interesse para este estudo, somente os seguintes solos foram estudados:

\section{a) Latossolo Verme1ho-Amarelo \\ o Latossolo Vermelho-Amarelo corresponde, segun-} do OLIVEIRA et alii (1982), à Unidade Lararja Azeda (LV3), que é a mais extensa da quadrícula de Araras, perfazendo 46,9\% dos latossolos e $21,1 \%$ da área total.

Esta unidade se encontra principalmente entre os paralelos $22^{\circ} 00^{\prime}$ 's e $22^{\circ} 30^{\prime} \mathrm{s}$ e os meridianos $47^{\circ} 00^{\prime} \mathrm{WG}$ e $47^{\circ} 15^{\prime} \mathrm{WG}$, nas cotas 580 a 710 metros.

Esta unidade recebe a seguinte classificação:

- Latossolo Vermelho-Amarelo álico, A moderado, textura média, relevo suave ondulado.

- Typic Haplorthox (USA).

- Orthic Ferralsol (FAO).

- Solo ferralítico fortemente dessaturado no B ( Fr) . 
Os solos desta unidade apresentam as seguintes caracteristicas:

1. horizonte A moderado;

2. textura inédia no horizonte B, com teor de argila superior a $25 \%$ ou, se entre 20 e $25 \%$, apresenta teor de areia fina superior ao de areia grossa;

3. carâtèr âlico ou distrófico;

4. ausência de acréscimo escalonado de argila, en tre os horizontes $A_{1}, A_{3}, B_{1}$ e $B_{2}$;

5 . horizonte $B_{2}$ apédico ou com estrutura subangular fraca;

6. ausência de mosqueamento a menos de $100 \mathrm{~cm}$;

7. cor 7,5 YR ou mais vermelha no horizonte $B_{2}$.

Ainda segundo OLIVEIRA et alii (1982), esta unidade apresenta as seguintes características morfológicas:

- Horizonte A - Subdivide-se em $A_{1}$ ou Ap e $A_{3}$, sendo que a espessura raramente ultrapassa $40 \mathrm{~cm}$. A estrutura do $A_{1} \bar{e}$ em geral granular pequena e média fraca e a do $A_{3}$, subangu lar média fraca ou mesmo moderada/fraca. O horizonte Ap apresen ta, em consequência do manejo, ausência de uridades estruturais bem definidas. 0 que se observa são fragmentos, lembrando estru tura subangular fraca.

A consistência é ligeiramente dura ou mais bran 
da, friâvel, ligeiramente plástica e ligeiramente pegajosa.

A coloração mais comum é a bruno-avermelhado-escura, seguida de bruno-avermelhada, ambas centradas no matiz 5YR e com relação valor/croma superior a $3,5 / 3,5$;

- Horizonte B - Em decorrência da espessura dos horizontes $A, B_{1}$ e $B_{2}$, não foi observada, nos trabalhos de cam po, presença de horizontes $B_{3}$.

0 subhorizonte $B_{1}$ apresenta, em geral, estrutura subangular média fraca, enquanto $\mathrm{O}_{2} \mathrm{~B}_{2}$ é em geral apédico ou com estrutura subangular fraca.

A textura mais comum é a areno-barrenta, ocorren do, também, textura barrenta, ao passo que a consistência é semelhante à do horizonte A.

A cor mais comum é a vermelho-amarelada, centrada no matiz 5YR e com variação valor/croma, 4/5 e 4/6.

As características analíticas desta unidade de solo são apresentadas na Tabela 3 . 
Tabela 3 - Médias, seguidas dos respectivos erros padrões, de resultados de amostras da camada superficial (a) e subsuperficial (b), de várias características da unidade Laranja Azeda (1). (Fonte: OLIVEIRA et alii, 1982).

\begin{tabular}{|c|c|c|c|c|}
\hline CARACTERISTICAS & C A M A D A & MEDIA & \pm & ERRO PADRĀO \\
\hline \multirow[t]{2}{*}{$\mathrm{pH}$} & a & 4,8 & \pm & 0,2 \\
\hline & $\mathrm{b}$ & 4,6 & \pm & 0,1 \\
\hline \multirow[t]{2}{*}{$C\left(\begin{array}{l}0 \\
0\end{array}\right)$} & $\mathrm{a}$ & 1,1 & \pm & 0,2 \\
\hline & $\mathrm{b}$ & 0,6 & \pm & 0,1 \\
\hline \multirow[t]{2}{*}{$\mathrm{S}$ (e.mg/100g de TFSA) } & a & 1,3 & \pm & 0,5 \\
\hline & $\mathrm{b}$ & 0,4 & \pm & 0,1 \\
\hline \multirow[t]{2}{*}{$\mathrm{Al}^{3+}(\mathrm{e} \cdot \mathrm{mg} / 100 \mathrm{~g}$ de $\mathrm{TFSA})$} & a & 0,7 & \pm & 0,2 \\
\hline & $\mathrm{b}$ & 0,8 & \pm & 0,1 \\
\hline \multirow[t]{2}{*}{ CTC ( e.mg/100 g de argila) } & a & 23,5 & \pm & 2,5 \\
\hline & $\mathrm{b}$ & 11,7 & \pm & 0,9 \\
\hline \multirow[t]{2}{*}{$V\left(\begin{array}{l}0 \\
0\end{array}\right)$} & a & 23,8 & \pm & 9,0 \\
\hline & $\mathrm{b}$ & 11,7 & \pm & 2,1 \\
\hline \multirow[t]{2}{*}{ RC (e.mg/100g de argila) } & a & 9,3 & \pm & 2,0 \\
\hline & $\mathrm{b}$ & 4,4 & \pm & 0,5 \\
\hline \multirow[t]{2}{*}{$\mathrm{m}\left(\begin{array}{l}0 \\
0\end{array}\right)$} & a & 48 & \pm & 14,2 \\
\hline & $\mathrm{b}$ & 68 & \pm & 5,2 \\
\hline \multirow[t]{2}{*}{ Argila $\left(\begin{array}{l}0 \\
0\end{array}\right)$} & a & 22 & \pm & 2,1 \\
\hline & $\mathrm{b}$ & 27 & \pm & 1,2 \\
\hline \multirow[t]{2}{*}{ Silte $\left(\begin{array}{l}\% \\
0\end{array}\right)$} & $\mathrm{a}$ & 3 & \pm & 1 \\
\hline & $\mathrm{b}$ & 4 & \pm & 1 \\
\hline \multirow[t]{2}{*}{ Areia fina $\left(\begin{array}{l}0 \\
0\end{array}\right)$} & a & 46 & \pm & 4 \\
\hline & $\mathrm{b}$ & 46 & \pm & 2 \\
\hline \multirow[t]{2}{*}{ Areia grossa $\left(\begin{array}{l}0 \\
0\end{array}\right)$} & $\mathrm{a}$ & 29 & \pm & 5 \\
\hline & $\mathrm{b}$ & 23 & \pm & 2 \\
\hline
\end{tabular}

(1) Unidade de mapeamento LV3. 
b) Podzólico Vermelho-Amarelo

Segundo OLIVEIPA et alii (1982), a unidade Olaria (PV3)* que é a principal unidade de solo da área estudada, possui inclusão da üidade Santa Cruz (PV4)* e unidade Serrinha $(\mathrm{PV} 5)^{*}$.

Ainda segundo OLIVEIRA et alii (1982), a unidade Olaria é a mais extensa na quadrícula de Araras, entre aquelas da classe dos Podzólicos Vermelho-Amarelos com 40,5\%, correspon de a $4,7 \%$ da área total.

Esta unidade recebe a seguinte classificação:

- Podzólico Vermelho-Amarelo argilla de atividade baixa, distrófico ou álico, A moderado, textura argilosa ou média/argilosa.

- Typic Paleudult (USA).

- Dystic Nitosol (FAO).

- Solo ferralitico forte ou medianamente dessatu rado "lessivé" (Fr).

Os solos desta unidade apresentam as seguintes características:

1. argila de atividade baixa;

2. caráter álico ou distrófico;

3. textura argilosa ou média/argilosa;

4. discreta diferenciação de horizontes;

* Observação: na carta de solos do levantamento semidetalhado do Estado de São Paulo, quadrícula São Carlos, as unidades assinaladas re cebem, respectivamente, a seguinte notação: PV6, PV1, PV2. 
5. espessura dos horizontes $A+B \geqq 150 \mathrm{~cm} \mathrm{e}$

6. substrato: sedimentos finos do permocarbonífe ro.

Ainda segundo OLIVEIRA et alii (1982), a unidade Olaria apresenta as seguintes características morfológicas:

- Horizonte A - Subdivide-se em $A_{1}$ ou Ap e $A_{3}$. A espessura é em geral inferior a $50 \mathrm{~cm}$. A cor do horizonte A é pre dominantemente bruno avermelhado-escura, variando entre as nota ções 4YR 3/4 e 5YR 3/4; cores 1igeiramente avermelhadas (2,5YR) ou mais amareladas ( $7,5 Y R)$ também ocorrem, porém são menos comuns .

Essa unidade é muito cultiranda, daí ser difícil encontrar solos com estrutura não perturbada na camada superfi cial. Quando ocorre, é do tipo granular média no $A_{1}$ e subangu lar média fraca ou fraca/moderada no $A_{3}$. Nos terrenos agricultados, observa-se a predominância de torrões pequenos e médios no horizonte Ap.

A textura é geralmente argilosa; contudo em alguns pontos foi constatada textura média (areno-barrenta) ou muito argilosa. Observou-se um ponto com textura arenosa no Ap, o qual foi considerado como variação da unidade.

A consistência da amostra ümida é em geral friá vel, raramente firme, e a da amostra molhada, plástica e pegajosa.

A transição do horizonte A para o B é gradual e 
plana, raramente abrupta. Ọuando ocorre, essa transição nãoé se guida de mudança textural abrupta;

- Horizonte B - E em geral espesso, com mais de $150 \mathrm{~cm}$. Subdivide-se em $B_{1} t, B_{2} t e B_{3}$.

A cor mais comum é a bruno-avermelhado-escura, com matiz variando de $2,5 Y R$ a $5 Y R$ com relação valor/croma de $3 / 3$ a 3/4. Em geral é pequena a variação de cor ao longo do horizonte $B$, especialmente entre os subhorizontes $B_{1}$ e $B_{2}$, mantendo-se o matiz e variando o croma e/ou valor de meia a uma unidade. Colorações bruno-avermelhada (6YR) e vermelho-amarelada $(7,5 Y R)$ foram encontradas ocasionalmente.

A estrutura do $B_{2} t$ é subangular média moderada, mais raramente prismática que se romne em subangular moderada forte. A consistência da amostra úmida é firme ou friável e, a da amostra molhada, plástica e pegajosa, enquanto a cerosidade é, no mínimo, fraca, sendo geralmente moderada e comum.

0 horizonte $\mathrm{B}_{3}$ apresenta menor expressão de estrutura, consistência muito friável da amostra úmida e cerosidade fraca ou mesmo ausente, sendo, neste ültimo caso, um verdadeiro horizonte B latossólico ou óxico.

0 horizonte $B_{1} t$ apresenta, em geral, caracterís ticas morfológicas semelhantes ao $B_{2}$, variando apenas no menor grau de expressão da estrutura e da cerosidade.

As caracteristicas analiticas desta unidade de solo são apresentadas na Tabela 4. 
Tabela 4 - Médias seguidas dos respectivos erros padrões, de resultados de amostras da camada sunerficial (a) e subsuperficial (b), de várias características da unidade 01aria.

(Fonte: OLIVEIRA et alii, 1982).

\begin{tabular}{|c|c|c|c|c|}
\hline CARACTERISTICAS & $C A^{-} M A D A$ & MEDIA & \pm & ERRO PADRÃO \\
\hline \multirow[t]{2}{*}{$\mathrm{pH}$} & $\mathrm{a}$ & 5,3 & \pm & 0,3 \\
\hline & $\mathrm{b}$ & 4,8 & \pm & 0,3 \\
\hline \multirow[t]{2}{*}{$C\left(\frac{0}{0}\right)$} & a & 1,5 & \pm & 0,4 \\
\hline & $\mathrm{b}$ & 0,8 & \pm & 0,1 \\
\hline \multirow[t]{2}{*}{$\mathrm{S}$ (e.mg/100g de TFSA) } & $\mathrm{a}$ & 4,2 & \pm & 1,4 \\
\hline & $\mathrm{b}$ & 2,2 & \pm & 0,5 \\
\hline \multirow[t]{2}{*}{$\mathrm{Al}^{3+}($ e.mg/100g de TFSA $)$} & $\mathrm{a}$ & 0,6 & \pm & 0,4 \\
\hline & $\mathrm{b}$ & 1,2 & \pm & 0,4 \\
\hline \multirow[t]{2}{*}{ CTC (e.mg/100g de argila) } & $\mathrm{a}$ & 20,6 & \pm & 2,5 \\
\hline & $\mathrm{b}$ & 9,6 & \pm & 0,9 \\
\hline \multirow[t]{2}{*}{$V\left(\frac{\%}{0}\right)$} & a & 52,1 & \pm & 0,8 \\
\hline & $\mathrm{b}$ & 37,5 & \pm & 8,0 \\
\hline \multirow[t]{2}{*}{$\mathrm{RC}$ (e.mg/100g de argila) } & $\mathrm{a}$ & 12,4 & \pm & 2,3 \\
\hline & $\mathrm{b}$ & 5,5 & \pm & 0,6 \\
\hline \multirow[t]{2}{*}{ m $\left(\begin{array}{l}0 \\
0\end{array}\right)$} & a & 18 & \pm & 9 \\
\hline & $\mathrm{b}$ & 38 & \pm & 10 \\
\hline \multirow[t]{2}{*}{ Argila $\left(\frac{\%}{o}\right)$} & $\mathrm{a}$ & 42 & \pm & 8 \\
\hline & $\mathrm{b}$ & 63 & \pm & 5 \\
\hline \multirow[t]{2}{*}{ Silte $\left(\begin{array}{l}0 \\
0\end{array}\right)$} & $\mathrm{a}$ & 12 & \pm & 3 \\
\hline & $\mathrm{b}$ & 7 & \pm & 1 \\
\hline \multirow[t]{2}{*}{ Areia Fina $\left(\begin{array}{l}0 \\
0\end{array}\right)$} & $\mathrm{a}$ & 36 & \pm & 6 \\
\hline & $\mathrm{b}$ & 23 & \pm & 4 \\
\hline \multirow[t]{2}{*}{ Areia Grossa $(\stackrel{\circ}{0})$} & a & 10 & \pm & 4 \\
\hline & $\mathrm{b}$ & 6 & \pm & 3 \\
\hline
\end{tabular}


Como foi, dito esta unidade possui inclusão da unidade Santa Cruz (PV4), que segundo OLIVEIRA et alii (1982) se diferenciam por esta apresentar menor relação textural, ausência de mudança textural abrupta e maior espessura;

\section{c) Litossolo}

Para OLIVEIRA e PRADO (1984), os litossolos têm como principal característica a pequena espessura do solum, inferior a $40 \mathrm{~cm}$, e a ausência de horizonte diagnóstico de subsuperfície ou, se existente, é muito pouco espesso.

Em conseqüência da imaturidade, apresentam geral mente teores relativamente elevados de minerais primários menos resistentes ao intemperismo e minerais de argila do grupo das esmectitas, o que lhes confere elevadosvalores de capacidade de troca de cátions da fração argila.

A textura é bastante variada e está estreitamen te relacionada com a natureza do substrato.

A classificação do litossolo em estudo é a seguinte:

- Litossolos eutróficos e distróficos, A modera do, textura indiscriminada, sustrato sedimentos finos do permiano (Li-1);

- Typic Udorthent;

- Lithosols (FAO);

- Lithosols (Fr).

Além de litossolo, a área possui inclusões de Pod 
zólico Vermelho-Amarelo, sendo a unidade Santa Cruz (PV1) a prin cipal, além da unidade Serrinha (PV2) e de Solo Hidromórfico. Segundo OLIVEIRA e PRADO (1984), a unidade Santa Cruz recebe a seguinte classificação:

- Podzólico Vermelho-Amarelo, argila de atividade baixa, abrupto ou com relação textural acentuada, distrófico ou álico, A moderado, textura média/argilosa, média/muito argilosa ou argilosa;

As características morfológicas desta unidađe são:

- Horizonte A - Apresentam um horizonte A moderado ou mesmo proeminente, com espessura que raramente ultrapassa $30 \mathrm{~cm}$, e tex tura bastante variável, encontrando-se desde arenosa até argilc sa; contudo, ná área estudada, predominam os solos com textura média. A cor mais comum no horizonte $A_{1}$ ou Ap é a bruno-escura com notações Munsell 7,5YR 4/2 a 4/4, predominando as últimas. A diferença de cor entre a amostra seca e a úmida é em geral a centuada, sendo a seca bem mais clara, com duas a três unidades a mais em matiz e uma e meia a mais em croma. A ocorrência de A proeminente é rara devido à insuficiência de espessura.

A estrutura é geralmente composta de granular e subangular moderada e a consistência é dura, firme, plástica e pegajosa, à excesão dos horizontes com pouca argila, cuja consistência é friável.

A transição do horizonte A para o B é abrupta e plana. Não foi registrada a presença do horizonte $A_{2}$; 
- Horizonte B - O horizonte $B$ subdivide-se em $B_{1} t$, $\mathrm{B}_{2} \mathrm{t}$ e $\mathrm{B}_{3}$, sendo a espessura total raramente superior a $100 \mathrm{~cm}$.

A cor varia bastante, especialmente no matiz ten do sido registrada notação desde $2,5 Y R$ até $7,5 Y R$, sendo as rela ções valor/croma $4 / 4$ e $4 / 5$ as mais comuns. As diferenças de cor entre os horizontes $B_{1}$ e $B_{2}$ são pouco acentuadas; todavia, o $B_{3}$ é geralmente mais avermelhado ou de croma mais elevado.

A estrutura do borizonte $B_{2} t$ é bem desenvolvida, geralmente do tipo subangular média ou grande forte e a cerosidade, sempre presente, é comum ou abundante e moderada ou forte. No horizonte $\mathrm{B}_{3}$, a estrutura é menos desenvolvida e a cerosidade, ou não é evidente na observação de campo, ou é fraca e pouca.

A consistência da amostra seca ao longo do horizonte B é muito dura ou mais acentuada, especialmente nos horizontes $B_{1} t$ e $B_{2} t$, enquanto a consistência da amostra úmida é fir me, e a da amostra molhada, plástica e pegajosa.

Ainda segundo OLIVEIRA e PRADO (1984), as carac terísticas analíticas deste solo são apresentados na Tabela 5 . 
Tabela 5 - Características Analíticas da Unidade Santa Cruz. (Fonte: OLIVEIRA e PRADO, 1984).

\begin{tabular}{|c|c|c|c|c|c|c|c|c|c|c|c|}
\hline $\begin{array}{l}\text { HORI ZONTE } \\
\mathrm{e} \\
\text { ESPESSURA }\end{array}$ & $\mathrm{pH}$ & C & $\mathrm{s}$ & $\mathrm{Al}^{3+}$ & CTC & V & $\mathrm{m}$ & $\begin{array}{l}\mathrm{Ar} \\
\mathrm{gi} \\
\mathrm{ia}\end{array}$ & $\begin{array}{c}\text { Sil- } \\
\text { te }\end{array}$ & $\begin{array}{r}\text { Areia } \\
\text { Fina }\end{array}$ & $\begin{array}{l}\text { Areia } \\
\text { Grossa }\end{array}$ \\
\hline & & $\%$ & $\begin{array}{c}\text { e.mg } / 100 \varepsilon \\
\text { TFSA }\end{array}$ & & $\begin{array}{l}\mathrm{mg} / 100 \mathrm{~g} \\
\operatorname{argila}\end{array}$ & & & & $-\%$ & & \\
\hline$A 1-0-15$ & 5,1 & 1,4 & 2,8 & 1,1 & 28,5 & 40 & 28 & 25 & 5 & 47 & 23 \\
\hline B2t $50-70$ & 5,0 & 0,7 & 1,0 & 5,4 & 15,8 & 12 & 85 & 50 & 9 & 33 & 8 \\
\hline $\mathrm{A} 1-0-20$ & 5,1 & 0,6 & 4,4 & 0,7 & 26,5 & 43 & 14 & 38 & 14 & 36 & 12 \\
\hline B2t $60-80$ & 5,0 & 0,7 & 0,9 & 4,9 & 23,8 & 11 & 85 & 55 & 11 & 30 & 4 \\
\hline
\end{tabular}

\subsubsection{MATERIAL CARTOGRÁFICO}

3.1.2.1. Cartas utilizadas para a caracterização da área $\mathrm{A}$

a) Cartas planialtimétricas do IBGE (Superintenàên cia de Cartografia), na escala 1:50.000:

- Folha Rio Capetinga (SP), SF-23-Y-A-II-2, editada em 1971 .

- Folha Araras (SP), SF-23-M-II-3, editada em 1969.

- Folha Leme (SP), SF-23-M-II-1, editada em 1971. 
b) Cartas planialtimêtricas do Plano Cartográfico do Estado de São Paulo, Projeto Macro-Metrō pole, Instituto Geográfico e Cartográfico (IGC), na escala 1:10.000 editadas em 1979:

- Folha Fazenda Amazonas, SF-23-Y-A-II-2-SO-A

- Folha Fazenda Paineiras, SF-23-Y-A-II-2-SO-B

- Folha Bairro Caju, SF-23-Y-A-II-2-SO-C

- Folha Capão do Maracujá, SF-23-Y-A-II-2-SO-D

- Folha Fazenda Santa Inácia, SF-23-Y-A-II-1-SO-E

- Folha Fazenda Peroba, SF-23-Y-A-II-1-SO-F

- Folha Bom Jesus de Iguape, SF-23-Y-A-II-2-SO-E

- Folha Fazenda Sete Lagoas, SF-23-Y-A-II-2-SO-F

- Folha Fazenda Angélica, SF-23-Y-A-II-3-NO-A

- Folha Fazenda Bom Jesus, SF-23-Y-A-II-3-NO-B

- Folha Fazenda Rafatânia, SF-23-Y-A-II-2-SE-A

- Folha Fazenda Querência, SF-23-Y-A-II-2-SE-C

- Folha Córrego Fundo, SF-23-Y-A-II-2-SE-E

c) Carta de Solos do Levantamento Pedológico Semidetalhado do Estado de São Paulo: Quadrí cula de Araras, na escala 1:100.000 e editada em 1981 .

d) Mapa Geológico da folha de Campinas, Convênio DAEE/UNESP, na escala 1:250.000 e editada em 1982 . 
3.1.2.2. Cartas utilizadas para a caracterização da área B

a) Cartas planialtimétricas do IBGE (Superinten dência de Cartografia), na escala 1:50.000:

- Folha Corumbataí (SP) - SF-23-Y-A-I-2, editada em 1971 .

- Folha Rio C1aro (SP) - SF-23-M-I-4, editada em 1969 .

b) Cartas planialtimétricas do Plano Cartográfico do Estado de São Paulo, Projeto Nacro-Metrópole, Instituto Geográfico e Cartogräfico (IGC), na escala 1:10.000 editadas em 1979:

- Folha Fazenda S. Luiz do Cuscuzeiro - SF-23-Y-A-I-2-SO-D

- Folha Fazenda Santo Urbano - SF-23-Y-A-I-2-SE-C

- Folha Corumbataí I - SF-23-Y-A-I-2-SE-F

- Folha Corumbataí II - SF-23-Y-A-I-2-SE-E

- Folha Fazenda Sant 'Ana de Baixo - SF-23-Y-A-I-4-NO-B

- Folha Bairro Ferraz - SF-23-Y-A-I-4-NE-A

c) Carta de Solos do Levantamento Pedológico Semidetalhado do Estado de São Paulo: Quadrícula de São Carlos, na escala 1:100.000 e editada em 1981 .

d) Mapa Geológico da folha de Campinas, Convênio DAEE/UNESP, na escala 1:250.000 e editada em 1982 . 


\subsubsection{MATERIAL FOTOGRÁFICO}

Foram utilizadas fotografias aëreas verticais pancromáticas, provenientes da cobertura aerofotogramétrica do Estado de São Paulo (1978), executada pela Terrafoto Atividades de Aerolevantamentos S.A. para a Secretaria do Planejamento do Estado de São Paulo. As cópias empregadas na fase de interpreta ção fotográfica deste trabalho pertencem ao Planalsucar e apresentam as seguintes características:

- Escala aproximada: 1:35.000;

- Dimensões: $23 \mathrm{~cm} \times 23 \mathrm{~cm}$;

- Area coberta por fotografia: cerca de $64,8 \mathrm{~lm}^{2}$;

- Recobrimento aproximado: 60\% entre fotografias na faixa de vôo e 30\% entre fotografias de fai xas adjacentes.

\subsubsection{EQUIPAMENTOS}

A visão estereoscópica foi obtida através de um estereoscópio de espelhos marca WILD, modelo ST-4, com ocular de três aumentos.

Foram utilizados equipamentos simples de medição e desenho como escalímetro, régua de precisão, curvímetro e compasso.

0 traçado de informações obtidas das diversas $\underline{i}$ magens foi efetuado sobre folhas transparentes de poliéster estável ("ultraphan"). 


\subsection{MÉTODOS}

\subsubsection{SELECÃO DAS ÁREAS DE ESTUDO}

Para se atingir um dos objetivos deste traba1ho, que é o de comparar os parâmetros de relevo obtidos de car tas planialtimétricas em escalas diferentes, selecionaram-se áreas que se encontravam representadas nas duas cartas e nos mapas pedológicos do levantamento semidetalhado do Estado de São Paulo.

Portanto, o primeiro critério foi o de selecionar áreas facilmente identificadas nas três cartas citadas; isto foi feito com o auxílio dos mapas de solos e do Inventário Cartográfico do Estado de São Paulo que foi elaborado pela Secretą ria da Indústria, Comércio, Ciência e Tecnologia do Estado em 1981 .

Finalmente, com base nos critérios citados chegou-se à ârea de estudo, que está compreendida entre os paralelos $22^{\circ} 00^{\prime} \mathrm{s}$ e $22^{\circ} 30^{\prime} \mathrm{S}$ e os meridianos $47^{\circ} 00^{\prime}$ 'WG e $48^{\circ} 00^{\prime}$ 'WG. Pos teriormente, com auxílio de fotoíndices da região, foram escolhidas as fotografias aéreas de ocorrência das respectivas unidades de solo, e que deveriam, portanto, conter as informações desejadas, segundo o método de "pesquisa lógica" sugerido por RABBEN (1960) e que consta de duas etapas: na primeira é efetua da a observação, coleta de dados, medição e identificação dos objetos registrados nas fotografias aéreas; a segunda envolve 
.64 .

indução e ou dedução de informações, que são aplicadas na solu ção do problema.

A identificação das fotografias que recobrem as áreas de interesse específico, dentro da área de estudo, foi feita através de exame do fotoíndice e da carta de solos da região, resultando na seguinte seleção:

a) Latossolo Vermelho-Anarelo (LV3):

- LV-1 - fotografias: 2223 a 2224

faixa de vôo: 04A

data: $29-07-78$

- LV-2 - fotografias: 2281 a 2283

faixa de vôo: 05A

data: $08-07-78$

- LV-3 - fotografias: 2224 a 2226

faixa de vôo: 04A

data: $29-07-78$

b) Podzólico Vermelho-Amarelo (PV3 + PV4):

- PV-1 - fotografias: 2326 a 2328

faixa de vôo: 06

data: $28-07-78$

- PV-2 - fotografias: 2324 a 2326

faixa de vôo: 06

data: $28-07-78$ 
- PV-3 - fotografias: 2326 a 2328

faixa de vôo: 06

data: $28-07-78$

c) Litossolo:

- Li-1 - fotografias: 2261 a 2263

faixa de vôo: 05

data: $10-07-78$

- Li-2 - fotografias: 2321 a 2323

faixa de vôo: 06

data: $28-07-78$

- Li-3 - fotografias: 2263 a 2265

faixa de vôo: 05

data: $10-07-78$

\subsubsection{OBTENCÃO DOS MAPAS BÁSICOS DE DRENAGEM}

Por meio de exames estereoscópicos das fotografias selecionadas foram traçados, sobre papel transparente, os canais de drenagem bem definidos, quer fossem cursos d'água per manentes ou temporärios, conforme sugeriram STRAHLER (1957), LUEDER (1959) e RAY (1963), e as depressões ümidas, indicadoras do grau de integração segundo LUEDER (1959). Cada conjunto de fotografias foi montado de acordo com o métódo de "matchlines", descrito pelo SOIL SURVEY STAFF (1962). 
Os decalques das redes de drenagem foram feitos conforme sugestão de RAY (1963), para facilitar o exame de certas características da d̀renagem, como tendências ou modificações do padrão, número e comprimento de rios e tributários, com a eliminação da exuberância de detalhes proporcionada pelas fotografias aẹreas.

\section{2:3. ANÁLISE DAS REDES DE DRENAGEM}

De acordo com BURINGH (1960), o estudo realizado foi do tipo "análise de elementos". Os elementos analisados referem-se às características descritivas e quantitativas dos padrões de drenagem.

Nos mapas de drenagem das äreas amostradas foi feita a contagem do número e medição do comprimento total dos canais da rede de drenagem.

A partir destes dados e dos valores da ärea da amostra e de seu perímetro, foram calculados os valores de densidade de drenagem, freqüência de rios e razão de textura.

A caracterização quantitativa dos padrões de drenagem foi restringida aos elementos disponíveis em amostras circulares, conforme método desenvolvido por RAY e FISCHER (1960) e ampliado por SOUZA (1975).

A densidade de drenagem (D) de cada amostra cir cular foi obtida segundo adaptação da fórmula de HORTON (1945) por RAY e FISCHER (1960) e é a seguinte: 


$$
D=\frac{L t}{A},
$$

onde Lt é o comprimento total de rios e A é a äreá da amostra circular.

A freqüência de rios (F) foi calculada segundo a adaptação de SOUZA (1975) da fórmula de HORTON (1945):

$$
F=\frac{N}{A},
$$

onde $\mathrm{N}$ é o número total de rios e $\mathrm{A}$ é a ärea da amosira circular.

A razão de textura (T) também foi calculada segundo SOUZA (1975), que adaptou a definição de SMITH (1950) modificada por FRANÇA (1968):

$$
\mathrm{T}=\frac{\mathrm{N}}{\mathrm{P}},
$$

onde $\mathrm{N}$ é o nümero total de rios e $\mathrm{p}$ é o perímetro da amostra circular.

Neste trabalho, nas fotografias aéreas selecionadas foram estudadas 3 amostras circulares de $10 \mathrm{~km}^{2}$, represen tativas da rede de drenagem de cada unidade de solo estudada.

\subsubsection{ANÁLISE DOS ÍNDICES DE RELEVO}

As amostras circulares de $10 \mathrm{~km}^{2}$, demarcadas so bre as fotografias aéreas na escala 1:35.000 para a obtençãodos indices de drenagem, foram transferidas nas devidas proporções 
para as cartas planialtimétricas nas escalas 1:10.000 e 1:50.000, sobre as quais foram determinados os seguintes indices de relevo: declividade média (dw). amplitude altimétrica máxima (Hm) e comprimento médio das vertentes (Cvm).

A declividade média ( $d w$ ) foi obtida segundo o método de.WENTWORTH (1930), adaptado por KOFFLER (1982) que, as sim como VALERIO FILHO (1984), obtiveram com este método resul tados satisfatórios, e o preconizam para amostragem circular, por apresentar valores consistentes e de mais rápida aplicação que o de STRAHLER (1956).

O método de WENTWORTH (1930) adaptado por KOFFLER (1982) para o cálculo da declividade média baseia-se no número de curvas de nível interceptadas por linhas dispostas nas dire ções Norte-Sul, Leste-Oeste, Noroeste-Sudeste e Nordeste-Sudoes te e respectivas paralelas, dentro da amostra circular transferida para a carta planialtimétrica, conforme indica a Figura 5 . o cálculo da declividade média (dw) é efetuado pela fórmula:

$$
\mathrm{dw}=\frac{\mathrm{EN} \cdot}{636,6} \text {, }
$$

onde $E$ é a equidistância vertical das curvas de nível em metros; $\mathrm{N}$ é o número médio de curvas interceptadas por quilômetro; e 636,6 é uma constante gerada pela transformação da fórmula original para o sistema métrico decimal. 
.69 .

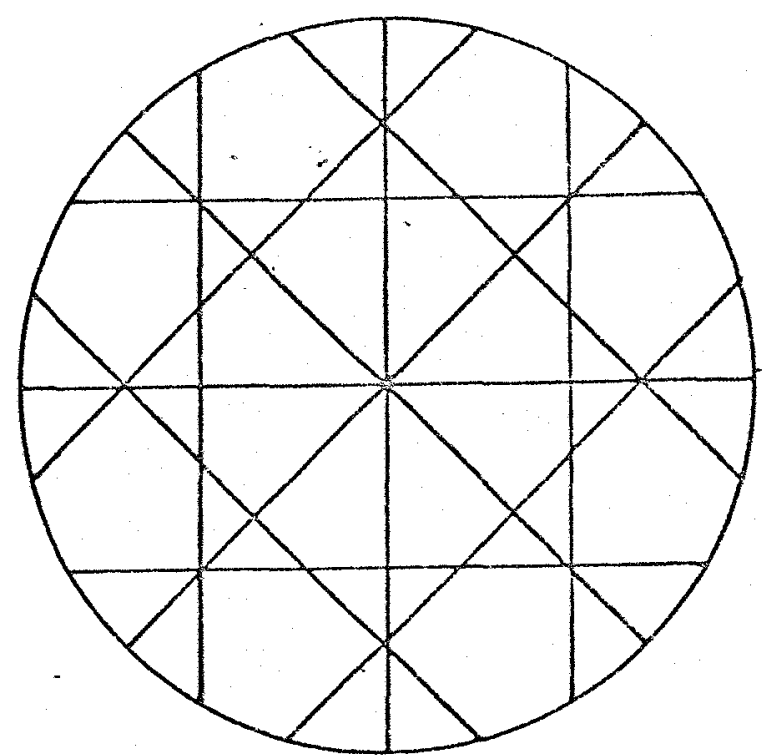

Figura 5 - Modelo da amostragem de WENTWORTH (1930) adaptado por KOFFLER (1982).

o segundo índice de relevo medido foi a ampli tude altimétrica máxima $(\mathrm{Hm})$, conforme sugestão de CHRISTOFOLETTI (1980), e que corresponde à diferença altimétrica entre a altitude da desembocadura e a média dos pontos mais elevados entre os canais de primeira ordem do trecho superior da bacia conside rada, devendo-se considerar no mínimo dez pontos cotados.

Este indice é semelhante ao relevo local médio, sugerido por GARCIA (1982) e utilizado por VALERIO FILHO (1984) que é obtido pela diferença entre a mais alta e a mais baixa elevação da área.

A amplitude altimétrica máxima foi obtida para cada amostra circular decalcada sobre as cartas planialtimétricas nas escalas $1: 10.000$ e $1: 50.000$.

A Fioura 6 representa esquematicamente a leitura da amplitude altimétrica máxima. 


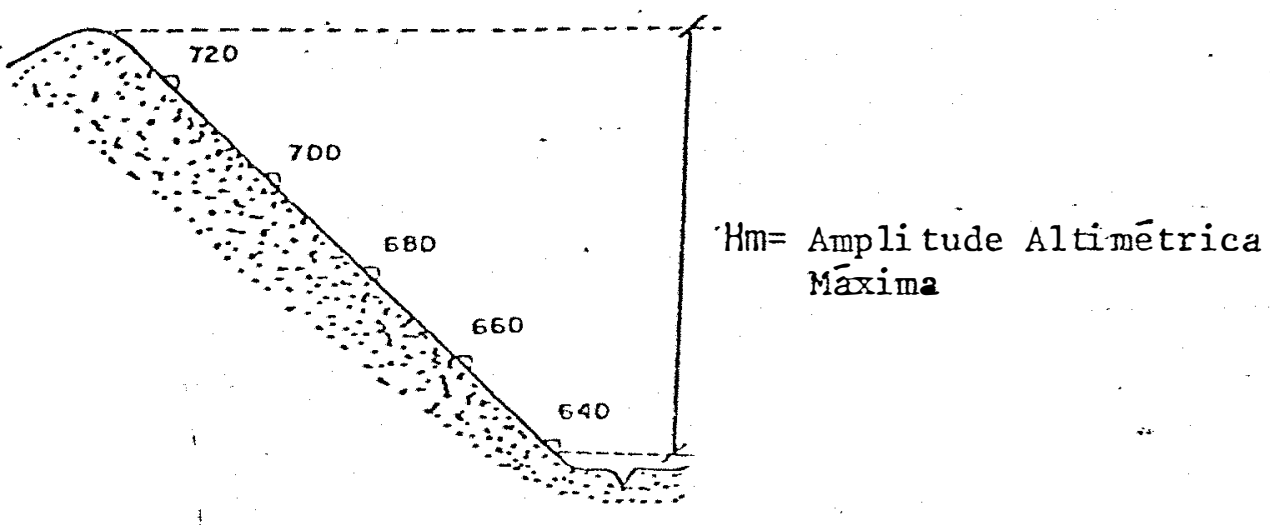

Figura 6 - Representação esquemática do sistema de leitura da amplitude altimétrica máxima. (Fonte: VALERIO FILHO, 1984).

0 terceiro índice do relevo analisado $\mathrm{e}^{-} \mathrm{o}$ comprimento médio da vertente (CVm) que, conforme o "Soil Conser vation Service" (1948), influencia o processo de erosão dos so los, uma vez que a velocidade de escoamento superficial da água pluvial aumenta com o comprimento da vertente, aspectos estes também considerados por TOY (1977) e QUEIROZ NETO (1978).

o comprimento médio das vertentes foi obtido conforme procedimento de VALERIO FILHO (1984), o qual consiste em medir, com auxílio de uma escala graduada, a distância entre os pontos de cotas mais elevadas e o canal de drenagem; neste trabalho procurou-se medir somente os comprimentos das linhas que eram normais aos canais de drenagem e, por cálculo, obteve-se o comprimento médio da vertente em metros, das leituras possíveis realizadas em cada amostra circular de $10 \mathrm{~km}^{2}$.

As medidas do comprimento médio das vertentes foram feitas para todas as amostras circulares delineadas sobre as cartas planialtimétricas nas escalas $1: 10.000$ e 1:50.000, con- 
forme mostra a Figura 7 .

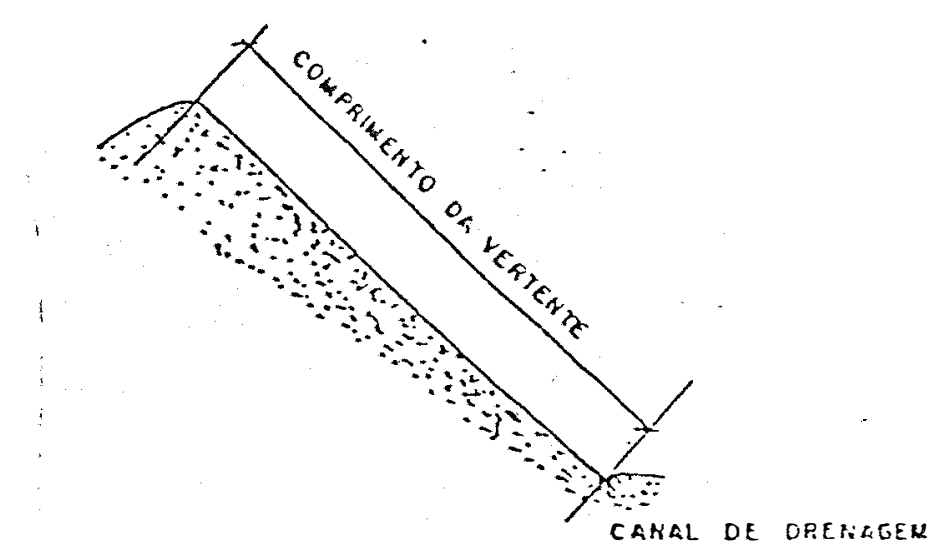

Figura 7 - Reñresentação esquemática da forma de leitura do comprimento médio da vertente. (Fonte: VALERIO FILHO, 1984).

\subsubsection{ANÁLISE ESTATISTICA}

Devido à pequena amostragem não foi possível aplí car a este trabalho nenhum teste estatístico paramétrico. Ao se tentar a análise estatística não paramétrica ocorreu outro problema que foi não evidenciar diferenças entre valores que visi.velmente são diferentes. Segundo CAMPOS (1983), is to ocorre por que, em geral, estes testes não levam em consideração a magnitude dos dados, pois é muito comum transformar os dados, de valores para simples ordens ou sinais e, em muitos casos, isto se traduz num desperdício de informações. Este fator foi comprovado por MANECHINI (1981), VALERIO FILHO (1984) e VETTORAZZI (1985). Desta forma optou-se por uma estatística simples, utilizando somente a comparação entre médias e erro pa- 
drão da média.

As fórmulas utilizadas foram as seguintes:

- média aritmética: $\bar{m}=\frac{\sum x}{n}$;

- variância: $s^{2}=\frac{\sum x^{2}-\frac{(\Sigma x)^{2}}{n}}{n-1}$

- erro padrão da média: $s(\bar{m})=\frac{s}{\sqrt{n}}$

- estimativa por intervalo $=\bar{m} \pm \frac{s}{\sqrt{n}}$ 


\section{RESULTADOS}

\subsection{Caracteristicas das amostras circulares}

\subsubsection{GEOLOGIA}

Do mapeamento geológico do Estado de São Paulo em escala 1:250.000, quadrícula de Campinas, e que foi executado em convênio entre o Departamento de Águas e Energia Elétrica e a UNESP, em 1982, foram demarcadas as amostras circulares dos três solos estudados para se determinar as suas formações geoló gicas.

De acordo com a Figura 8, nas amostras de Latos solo Vermelho-Amarelo, destacam-se as seguintes formações geoló gicas:

a) Formação Aquidauana (Carbonífero Permiano);

b) Formação Itararé (Carbonífero Permiano);

c) Depósitos coluviais (Plioceno-Pleistoceno). 
As formações geológicas que predominam nas amos tras circulares de Podzólico Vermelho-Amarelo e Litossol, são as formações Corumbataí e Pirambóia, como mostram as Figuras 9 e 10 .

\subsubsection{SOLOS}

Das cartas de solos do Levantamento Semidetalha do do Estado de São Paulo em escala 1:100.000, quadrículas de A raras e São Carlos, elaboradas respectivamente por OLIVEIRA et alii (1982) e OLIVEIRA e PRADO (1984), foram demarcadas as amos tras circulares para se determinar quais os solos e respectivas unidades que compunham as amostras, como mostram as Figuras 11, 12 e 13 .

\subsection{AMDSTRAS CIRCULARES REPRESENTATIVAS DA DRENAGEM E DO RELEVO}

As Figuras 14 a 16 representam as amostras circulares da drenagem, dos três solos estudados, obtidas pela inter pretação das fotografias aéreas verticais na escala 1:35.000.

As Figuras 17 a 25 correspondem às amostras cir culares extraídas das cartas planialtimétricas na escala 1:10.000 e as Figuras 26 a 28 são das amostras circulares obtidas das cartas planialtimétricas na escala 1:50.000. 


\section{3. CARACTERISTICAS DAS REDES DE DRENAGEM}

\section{3:1. COMPOSICÃO DA REDE DE DRENAGEM}

4.3.1.1. Número de rios

o número de rios observados, suas respectivas or dens, o número total de rios, o valor médio e seu respectivo er ro padrão, para as amostras circulares representativas dos solos em estudo, encontram-se na Tabela 6 .

4.3.1.2. Comprimento total de rios

o comprimento total de rios, o valor médio e seu respectivo erro padrão, para as amostras circulares dos solos em estudo, encontram-se na Tabela 7.

\subsubsection{CARACTERÍSTICAS DO PADRÃO DE DRENAGEM}

4. 3.2.1. Características descritivas do padrão de drenagem

A Tabela 8 fornece um resumo das características descritivas dos padrões de drenagem dos solos estudados. 

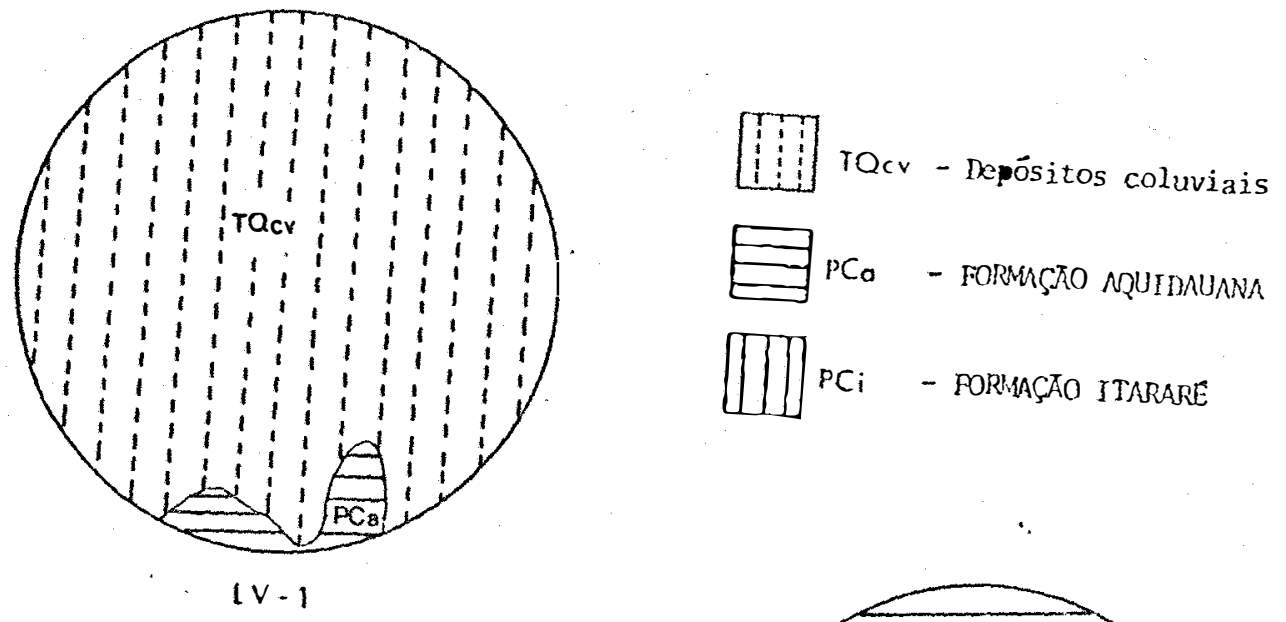

$\begin{array}{lll}1 & 1 & 1\end{array}$

$1,1, T_{c r} 1,1,1,1$
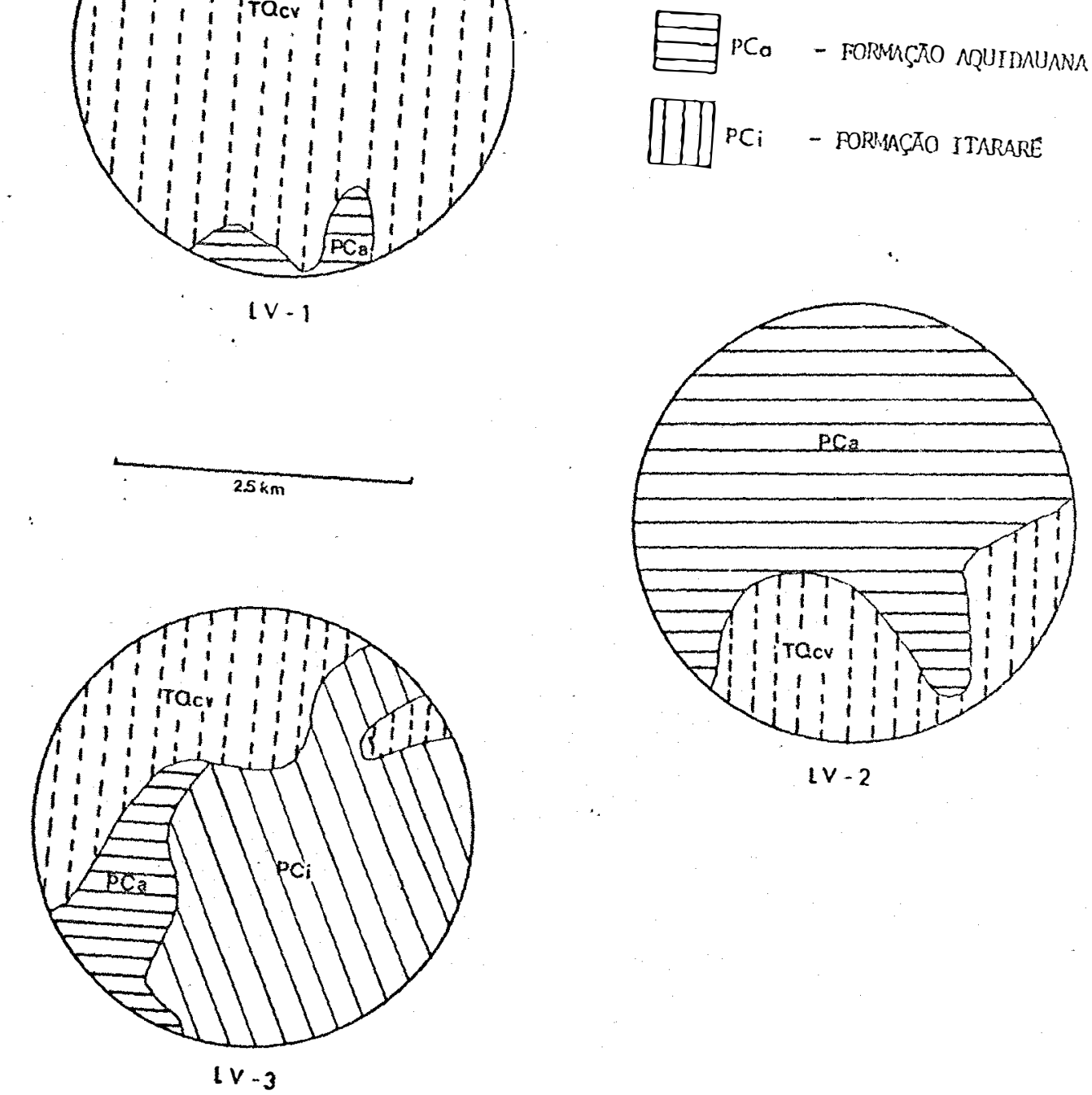
$\begin{aligned} & \text { Figura } 8 \text { - } \text { Representação das formações geolögicas que constituem as anos- } \\ & \text { tras de Latossolo Vermelho-Amarelo. }\end{aligned}$ 

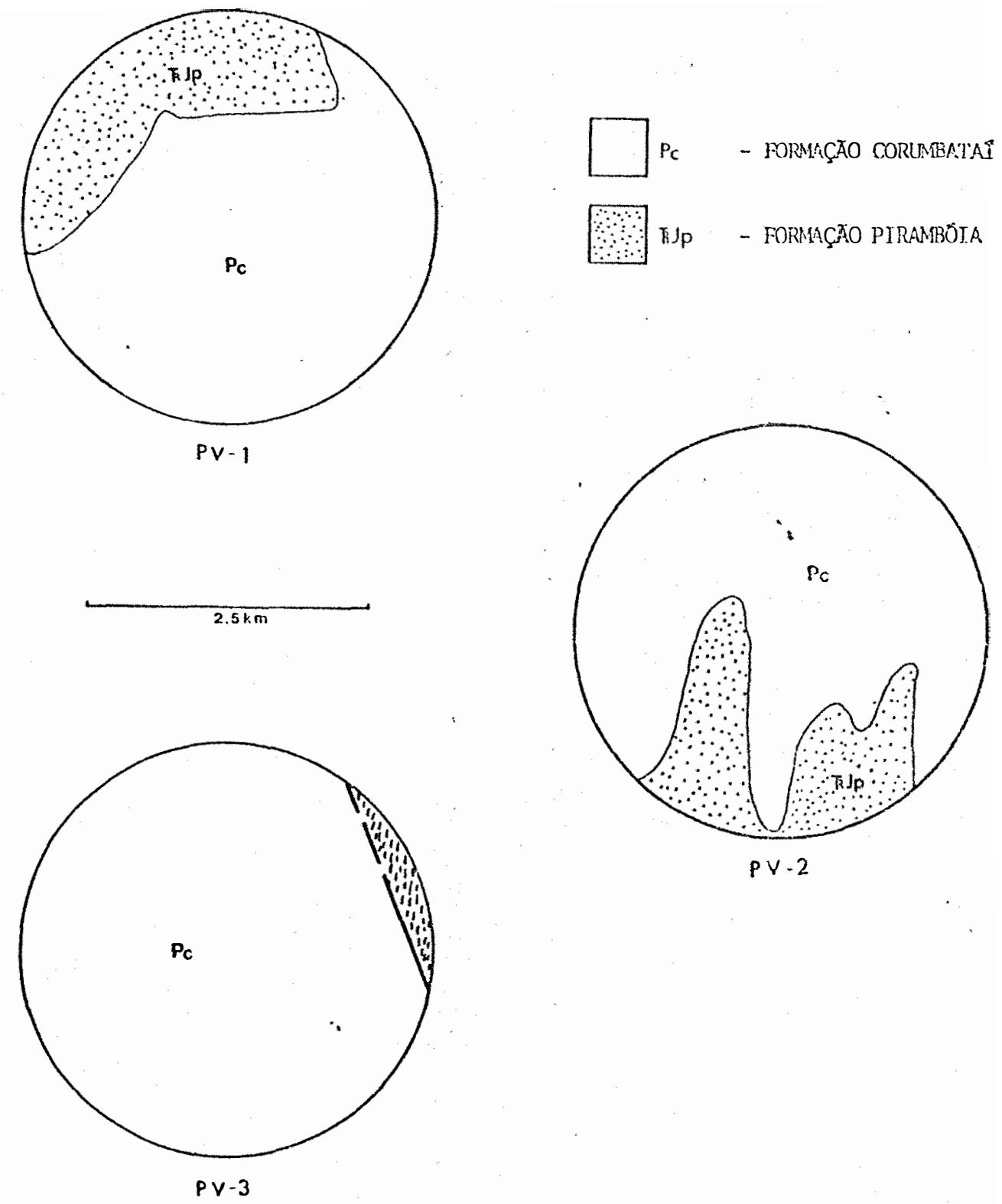

Figura 9 - Representação das formações geológicas que constituem as amostras de Podzólico Vermelho-Anarelo. 


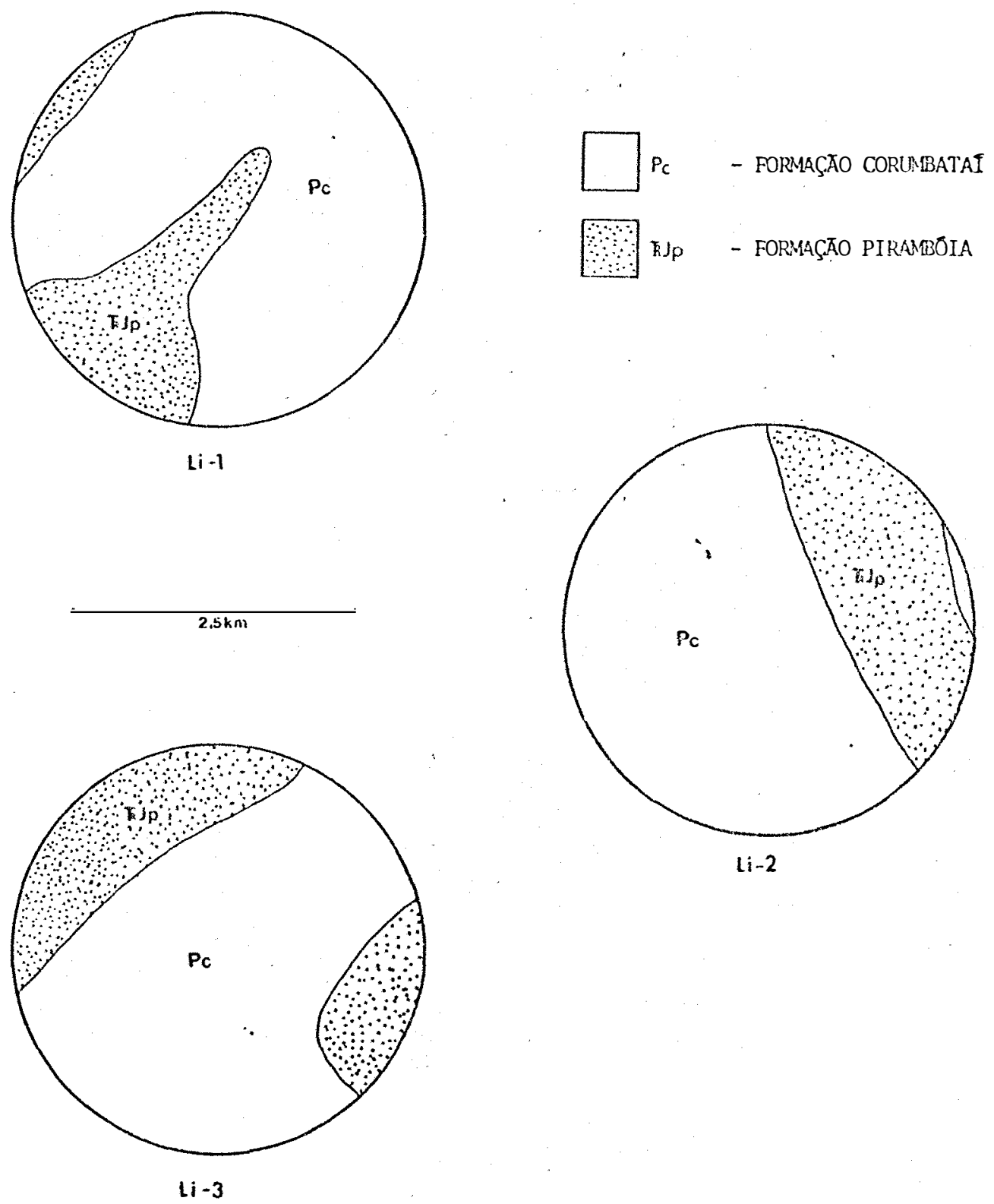

Figura 10 - Representação das formações geológicas que constituem as amostras circulares de Litossolo. 

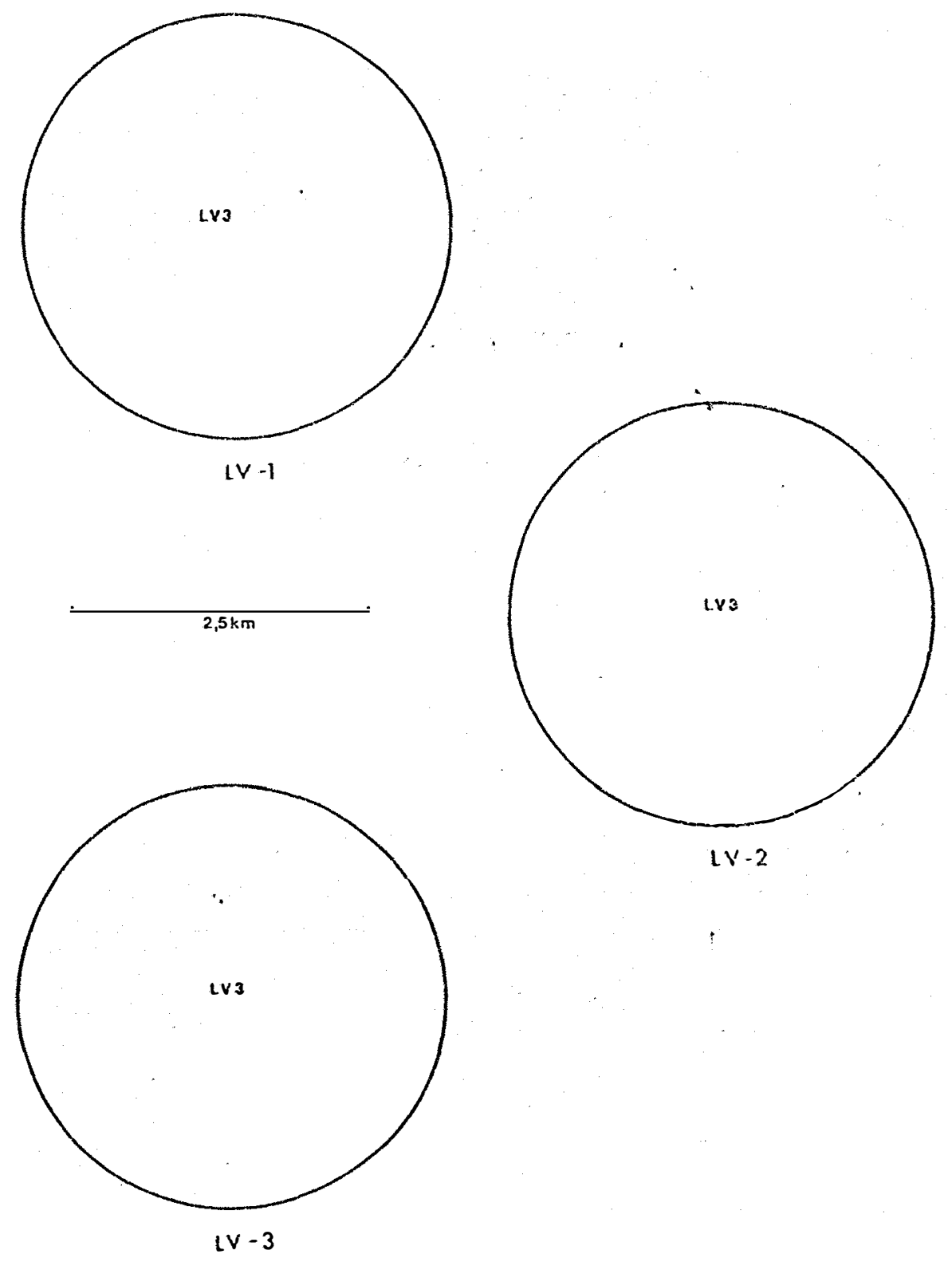

Figura 11 - Amostras circulares de Latossolo Vermelho-Anarelo, retiradas da Carta de Solos do Levantamento Pedológico Semidetalhado do Estado de São Paulo: Quadrícula de Araras. 

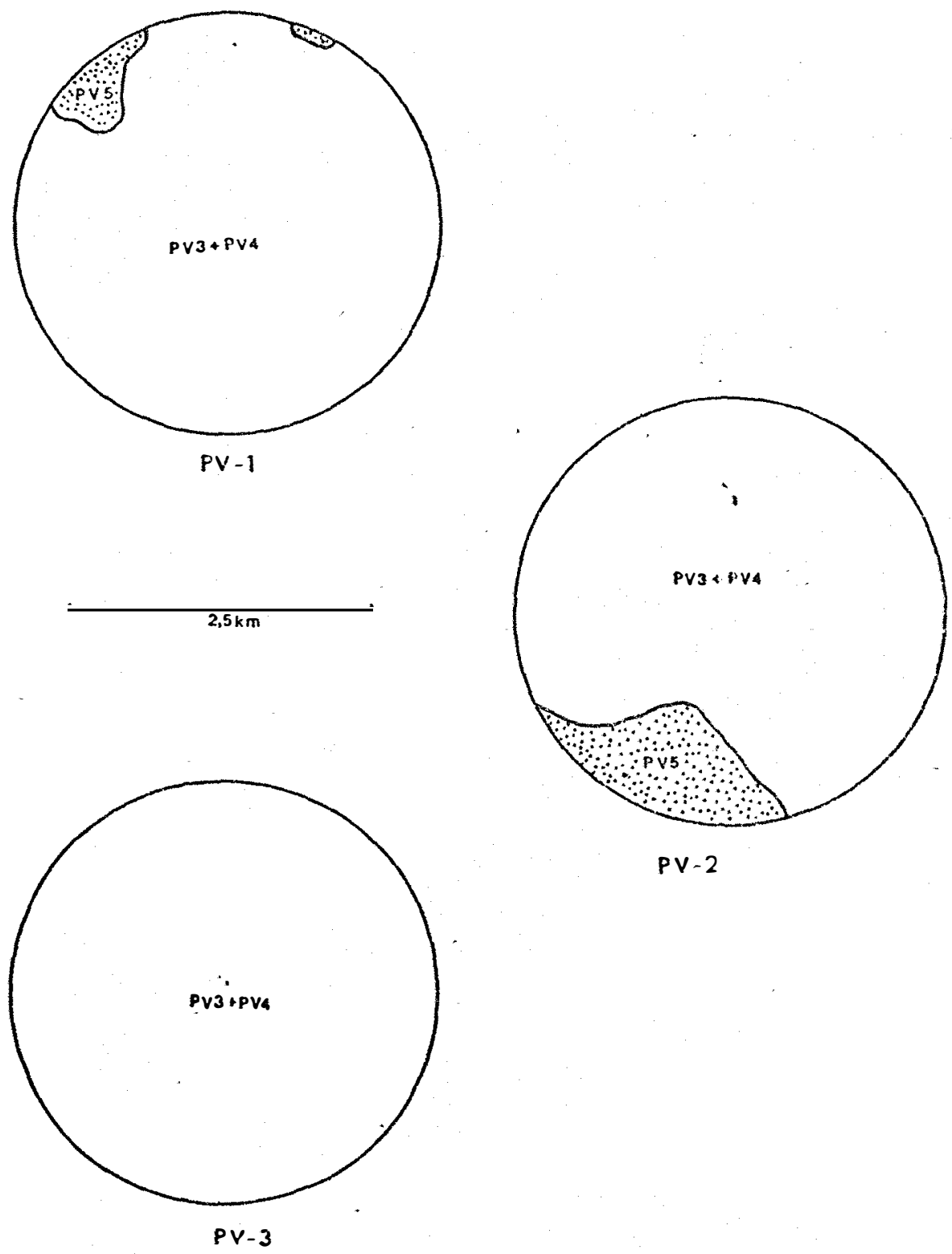

PV - 2

Figura 12 - Amostras circulares de Podzólico Vermeiho-Amarelo, retiradas da Carta de Solos do Levantamento Pedológico Semideta 1hado do Estado de São Paulo: Quadrícula de Araras. 


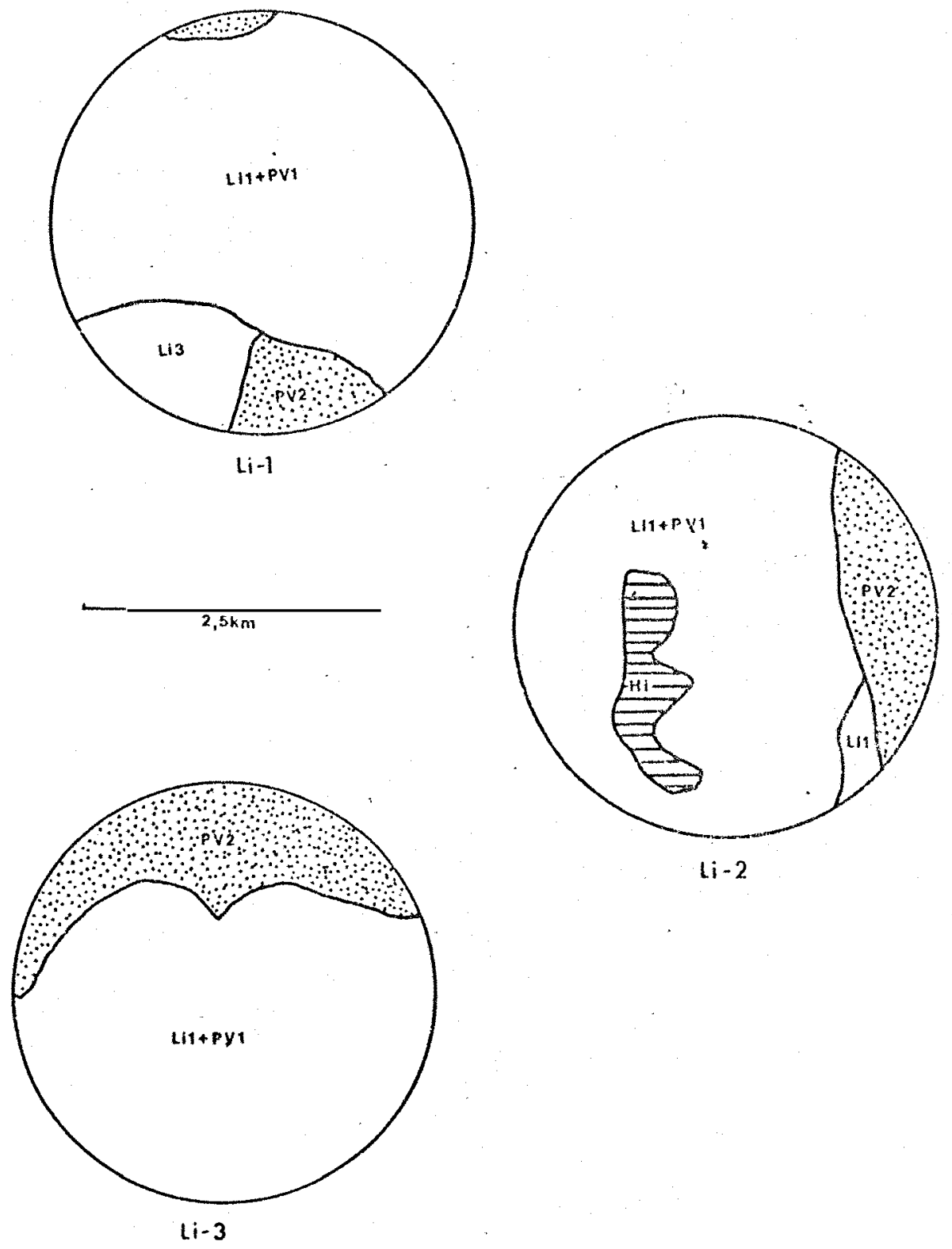

Figura 13 - Amostras Circulares de Litossolo, retiradas da Carta de Solos do Levantamento Pedológico semidetalhado do Estado de São Paulo: Quadrícula de São Carlos. 


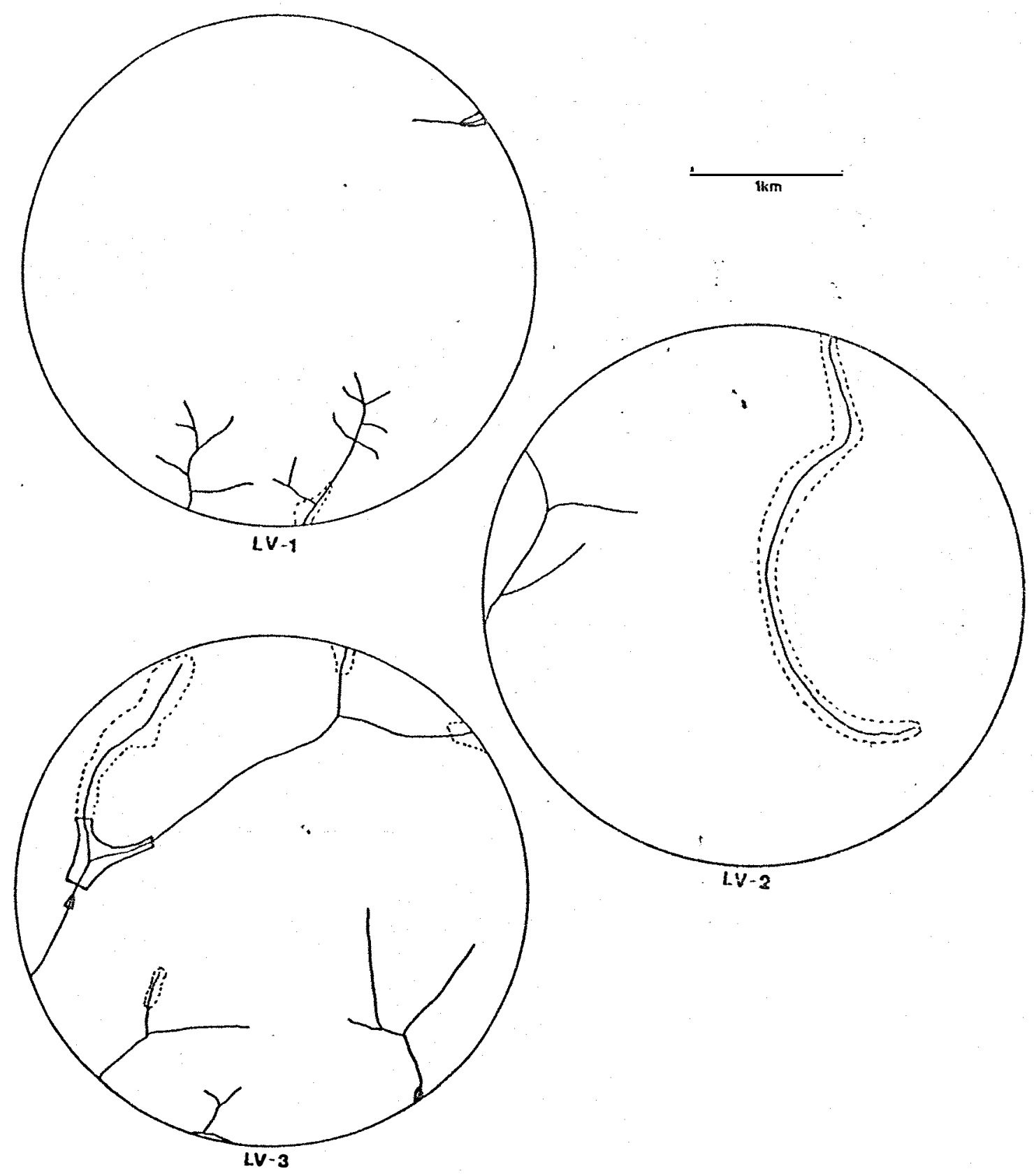

Figura 14 - Amostras Circulares LV-1, LV-2 e LV-3 (10 kn²) da rede de dre nagem em Latossolo Verme1ho-Amarelo - Escala 1:35.000. 
.83 .

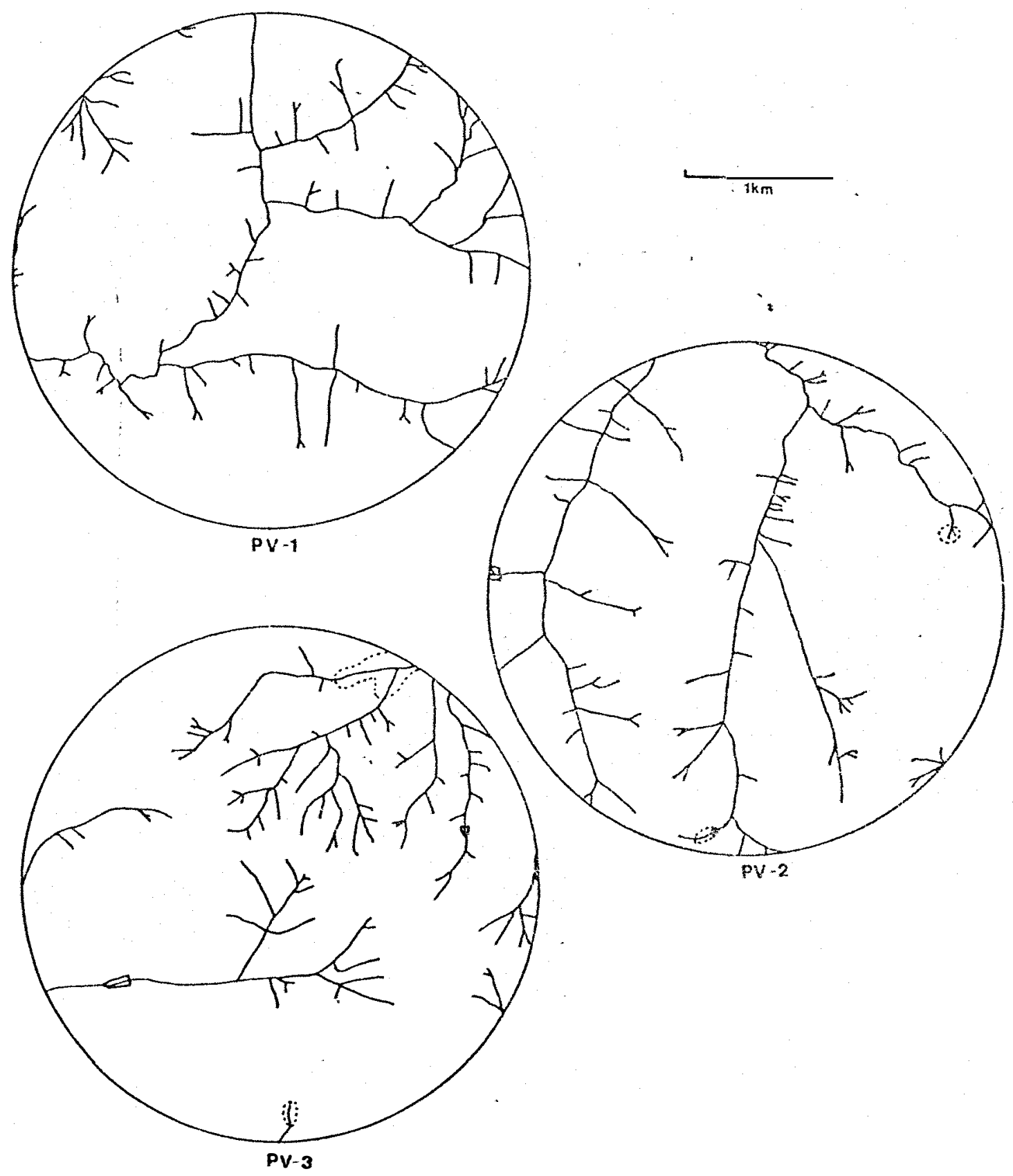

Figura 15 - Amostras Circulares PV-T, PV-2 e PV-3 $\left(10 \mathrm{~km}^{2}\right.$ da rede de drenagem em Dodzólico Vermelho-Amarelo. Escala 1:35.000. 


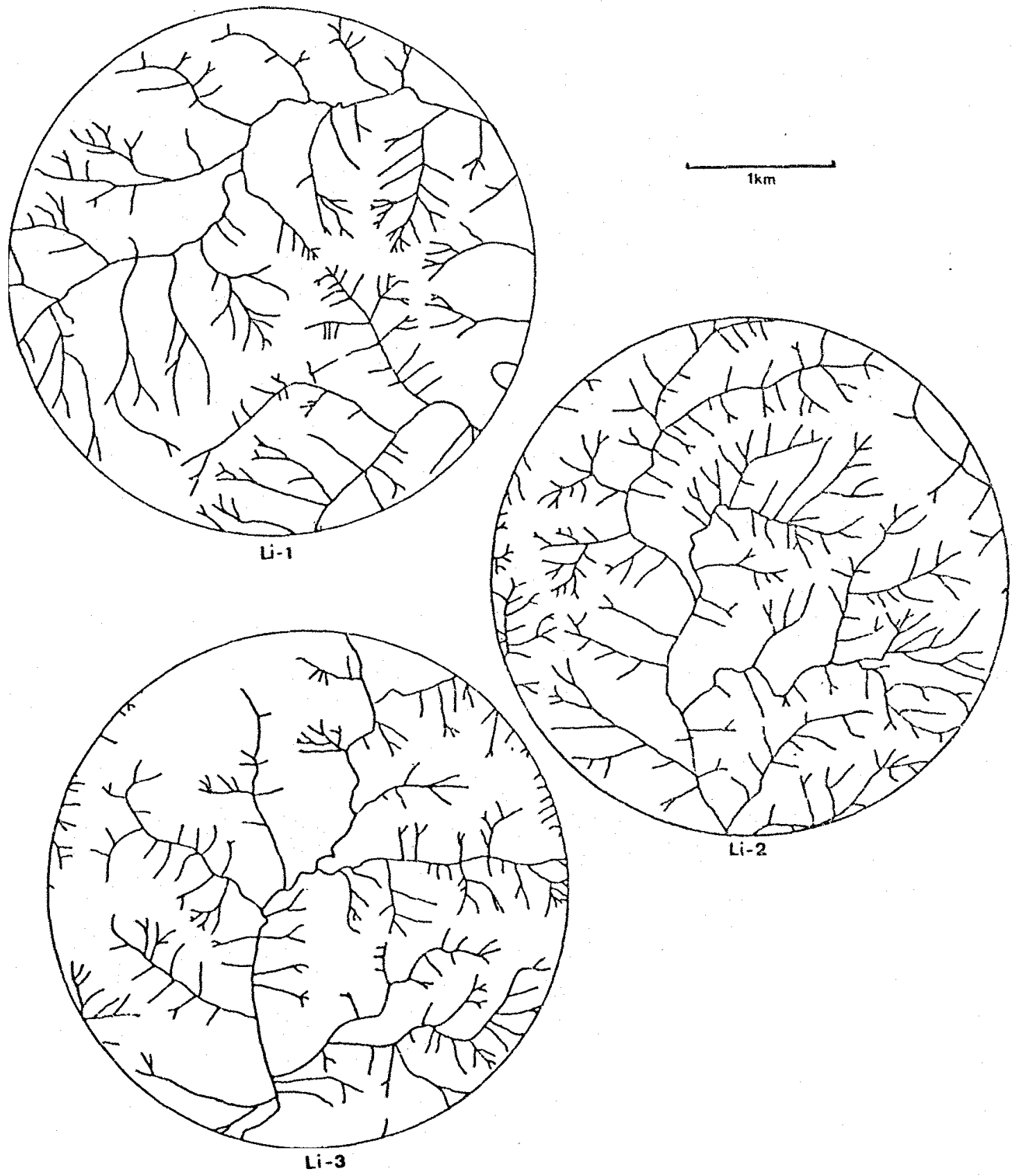

Figura 16 - Amostras Circulares Li-1, Li-2 e Li-3 (10 $\left.\mathrm{km}^{2}\right)$ da rede de drenagem em Litossolo. Escala 1:35.000. 
.85

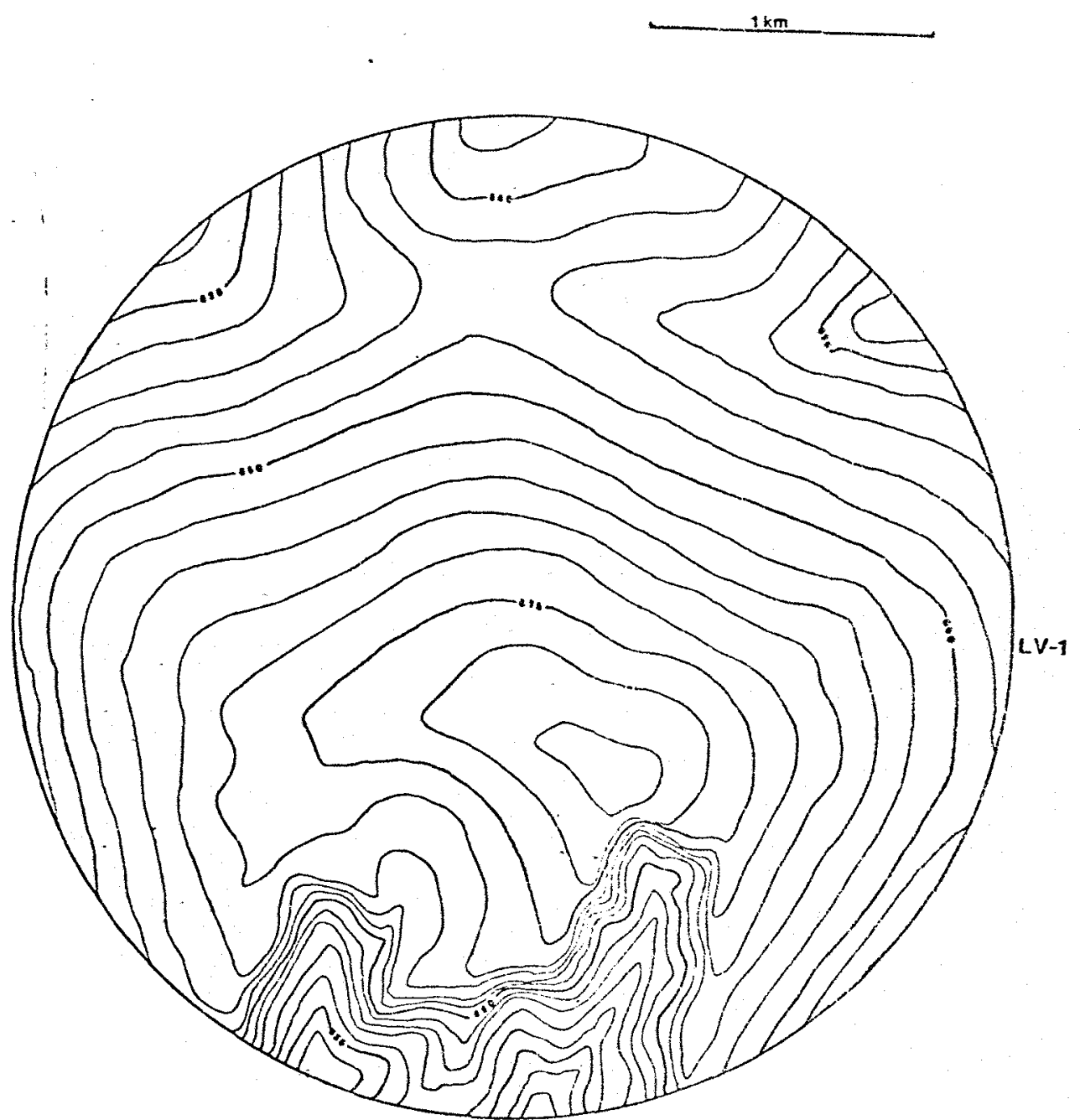

Figura 17 - Amostra Circular, LV-1 $\left(10 \mathrm{kn}^{2}\right)$, do relevo em Latossolo Vermelho-Amarelo. Escala 1:10.000. 


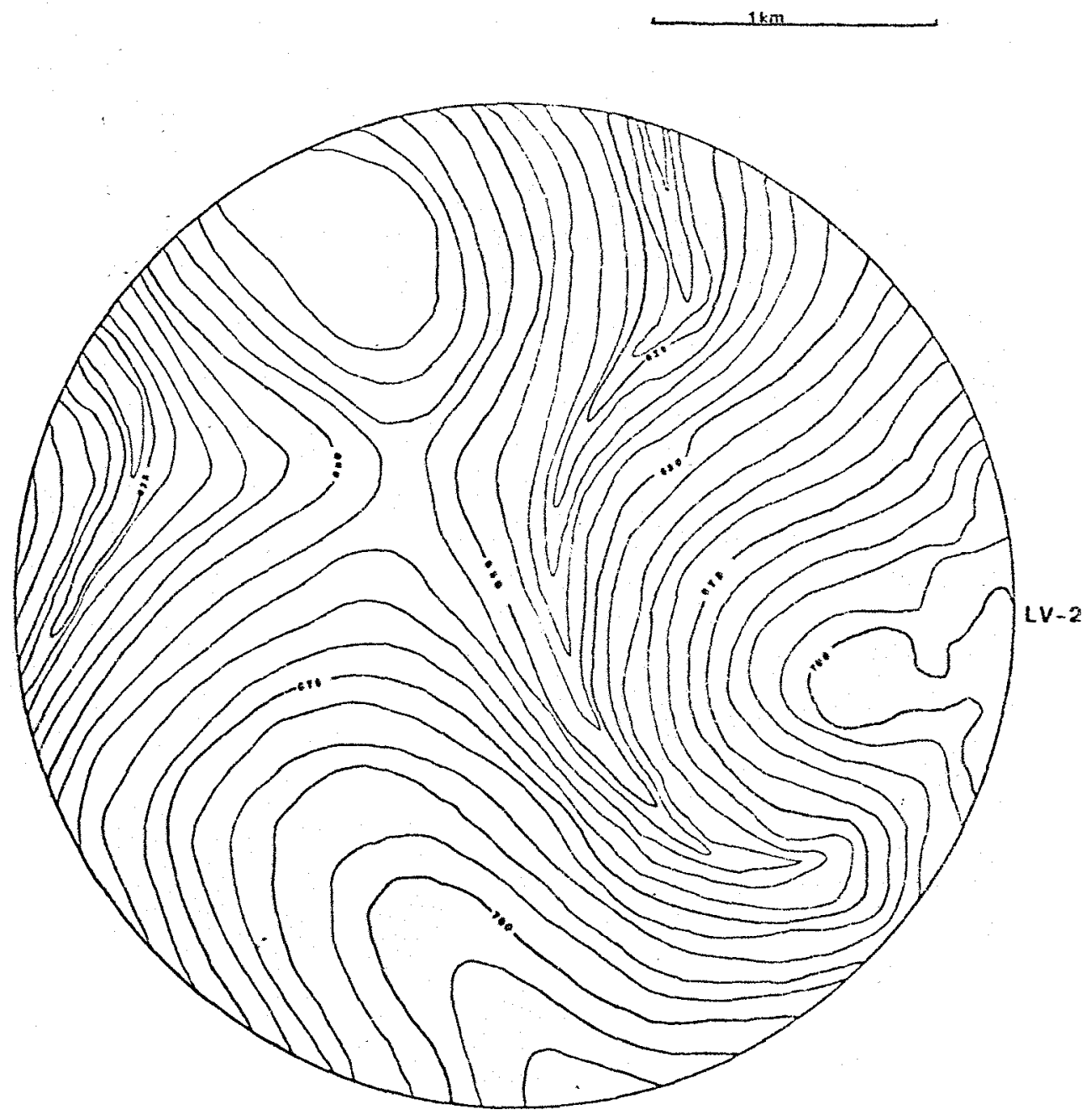

Figura 18 - Amostra Circular, LV-2 $\left(10 \mathrm{~km}^{2}\right)$, do relevo em Látossolo Vermelho-Amarelo. Escala 1:10.000. 


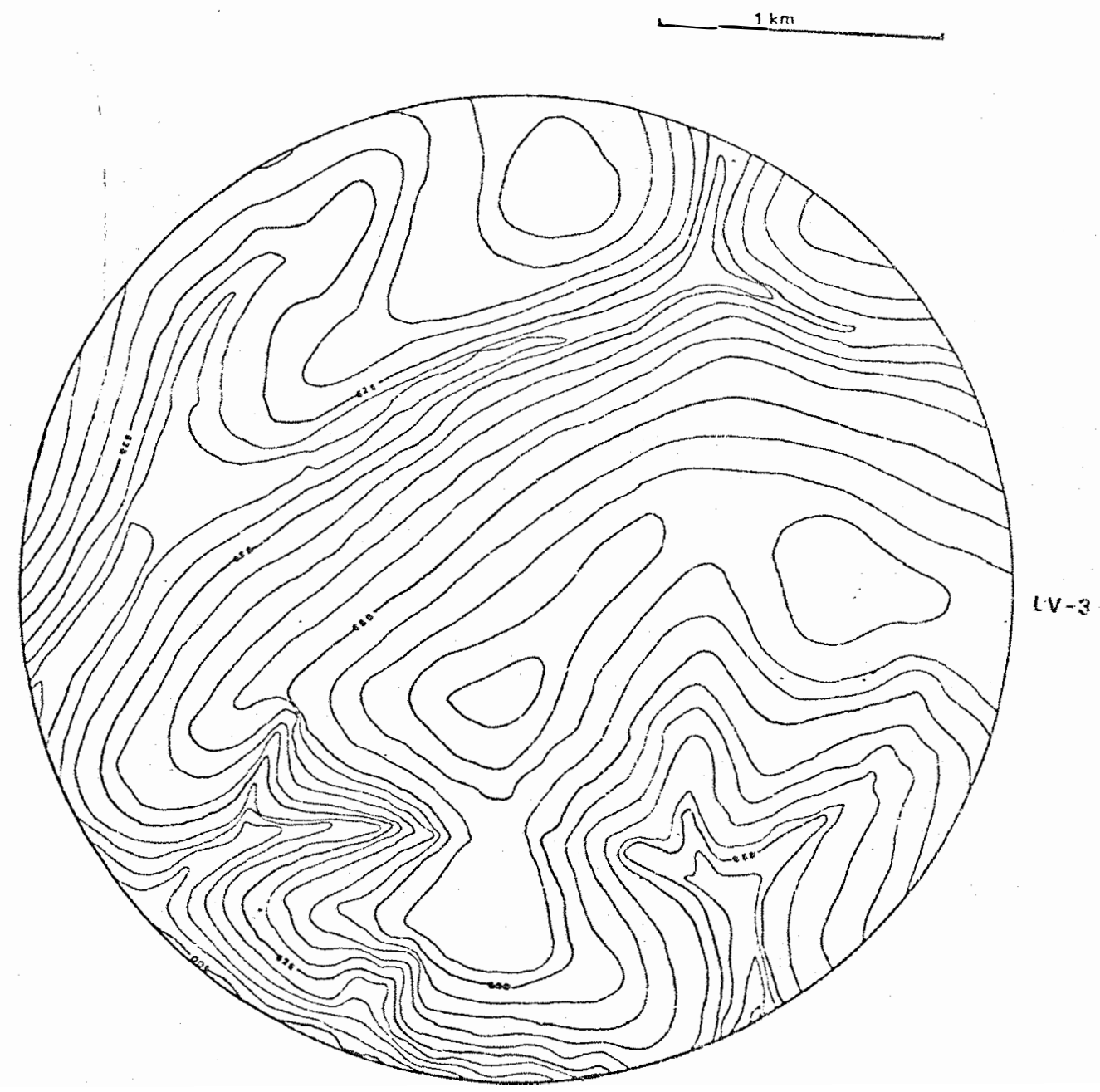

Figura 19 - Amostra Circular, I.V-3 (10 km²), do relevo em Latossolo Vermelho-Amarelo. Escala 1:10.000. 
.88 .

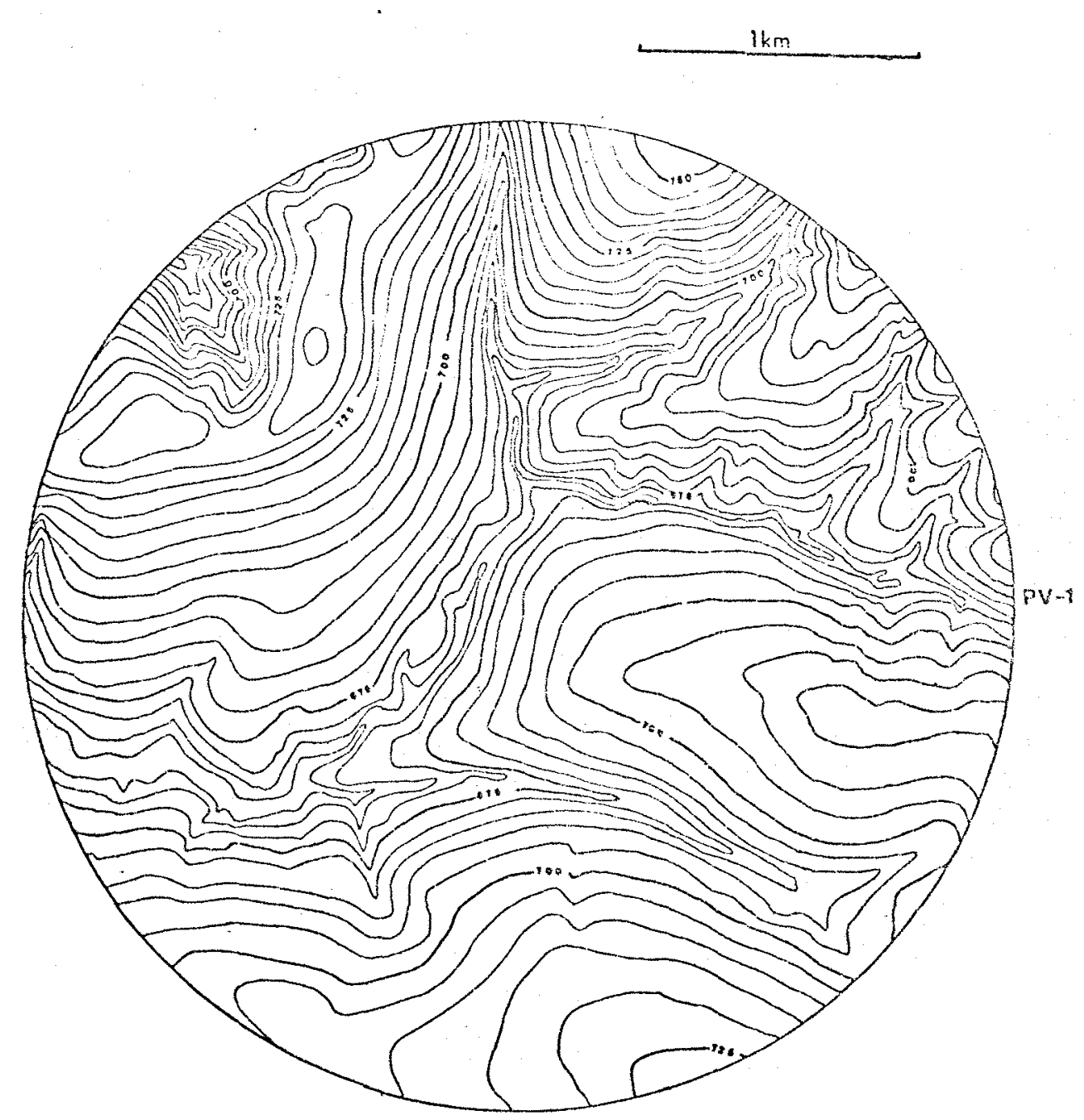

Figura 20 - Amostra Circular, PV-1 $\left(10 \mathrm{~km}^{2}\right)$, do relevo em Podzölico Vermelho-Amarelo. Escala 1:10.000. 


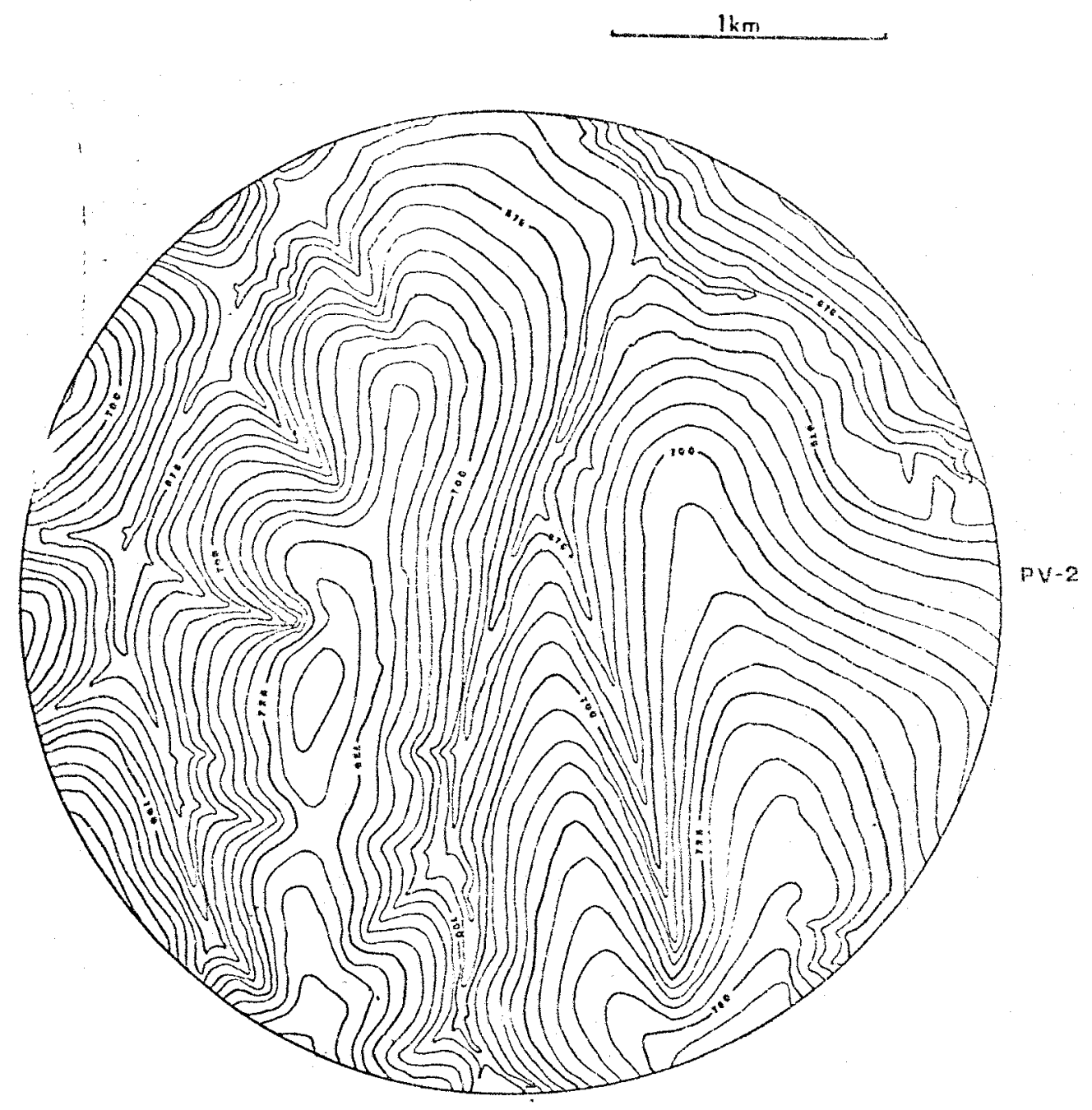

Figura 21 - Amostra Circular, PV-2 $\left(10 \mathrm{kn}^{2}\right)$, do relevo em Podzólico Vermelho-Amarelo. Escala 1:10.000. 
.90.

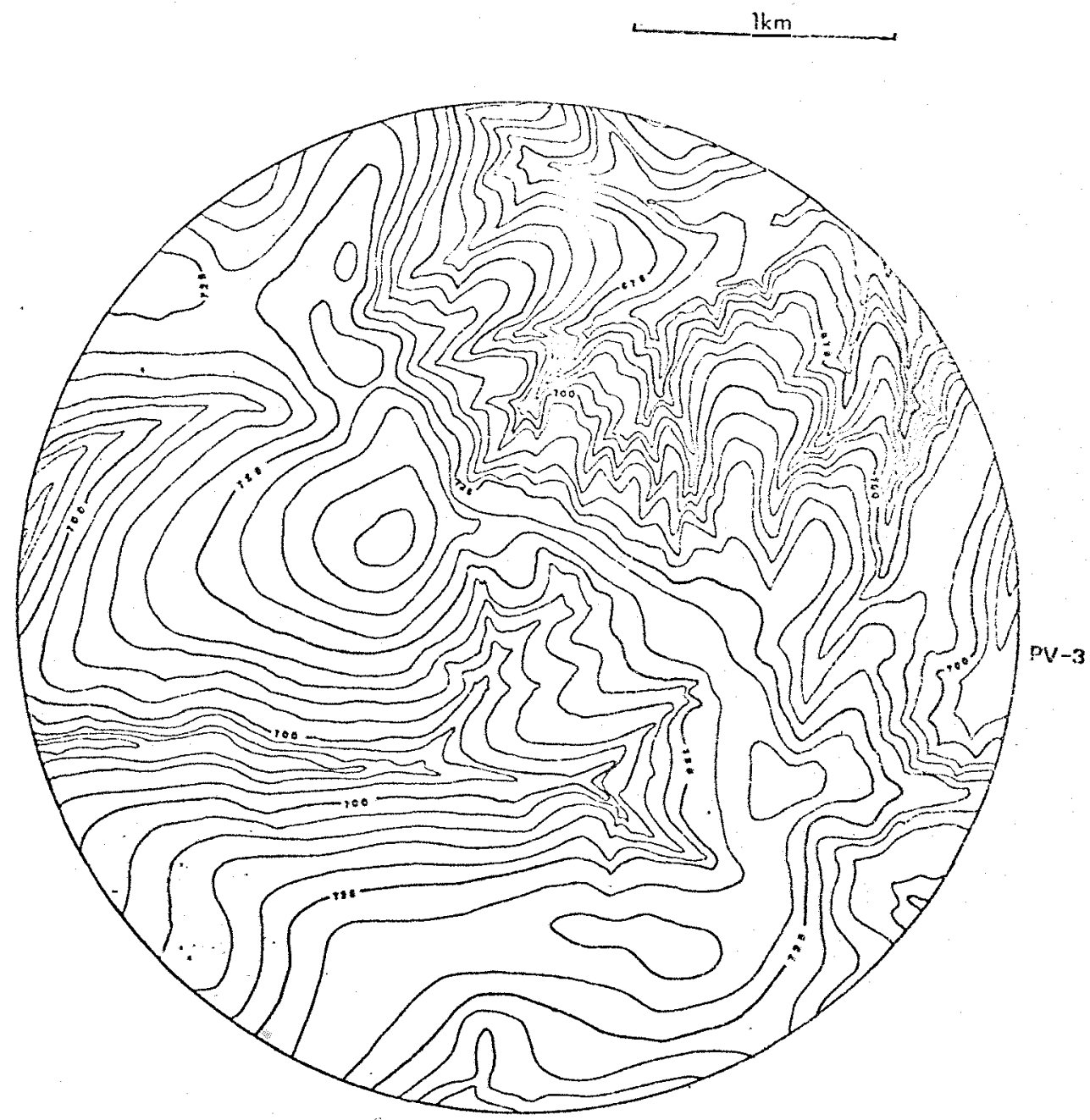

Figura 22 - Amostra Circular, PV-3 $\left(10 \mathrm{~km}^{2}\right)$, do relevo em Podzólico Vermelho-Amarelo. Escala 1:10.000. 
.91.

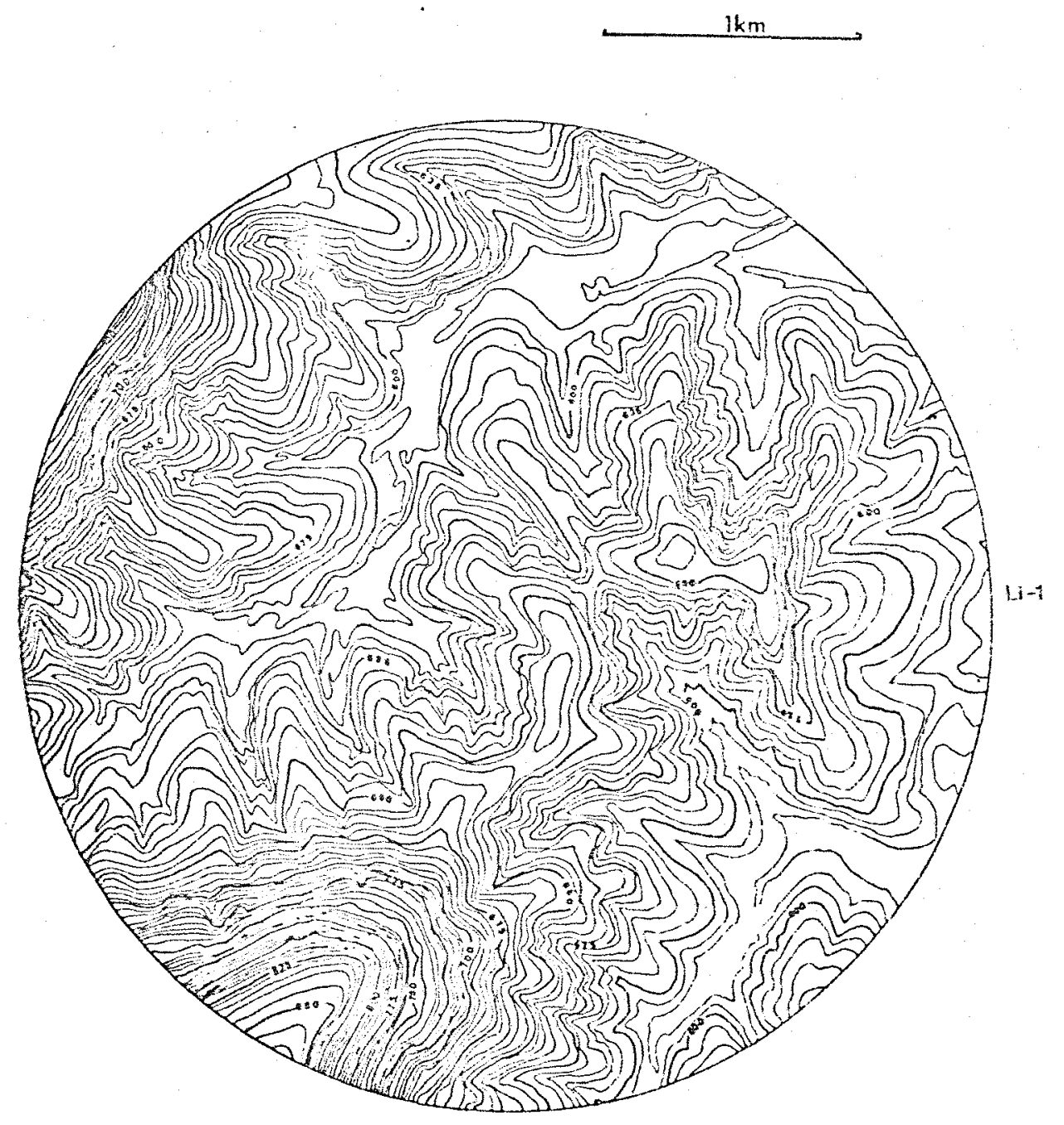

Figura 23 - Amostra Circu?ar, Jil-1 $\left(10 \mathrm{~km}^{2}\right)$, do relevo em Litossolo. Escala 1:10.000. 


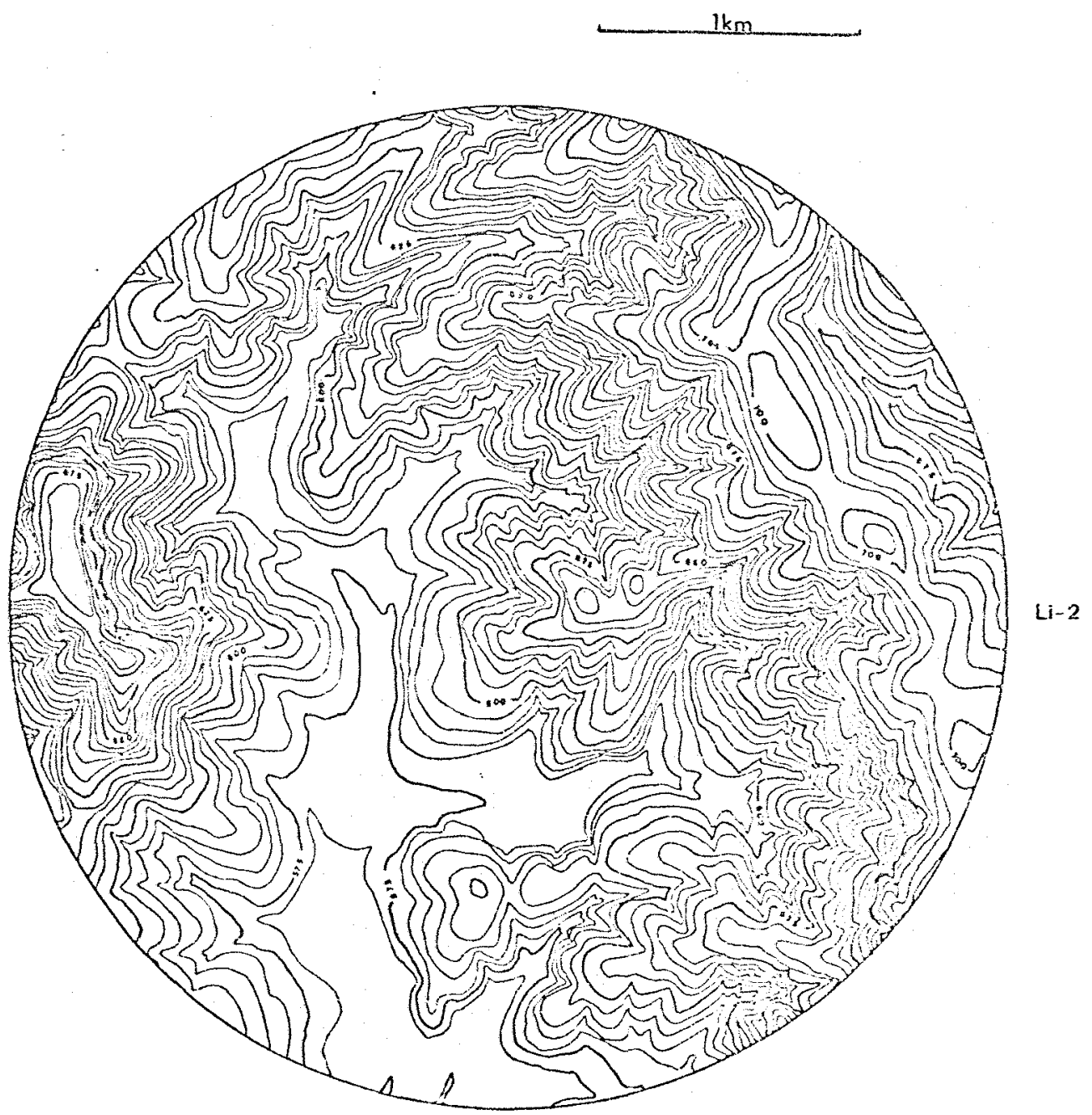

Figura 24 - Anostra Circular, Li-2 $\left(10 \mathrm{~km}^{2}\right)$, do relevo em Litossolo. Escala 1:10.000. 
.93.

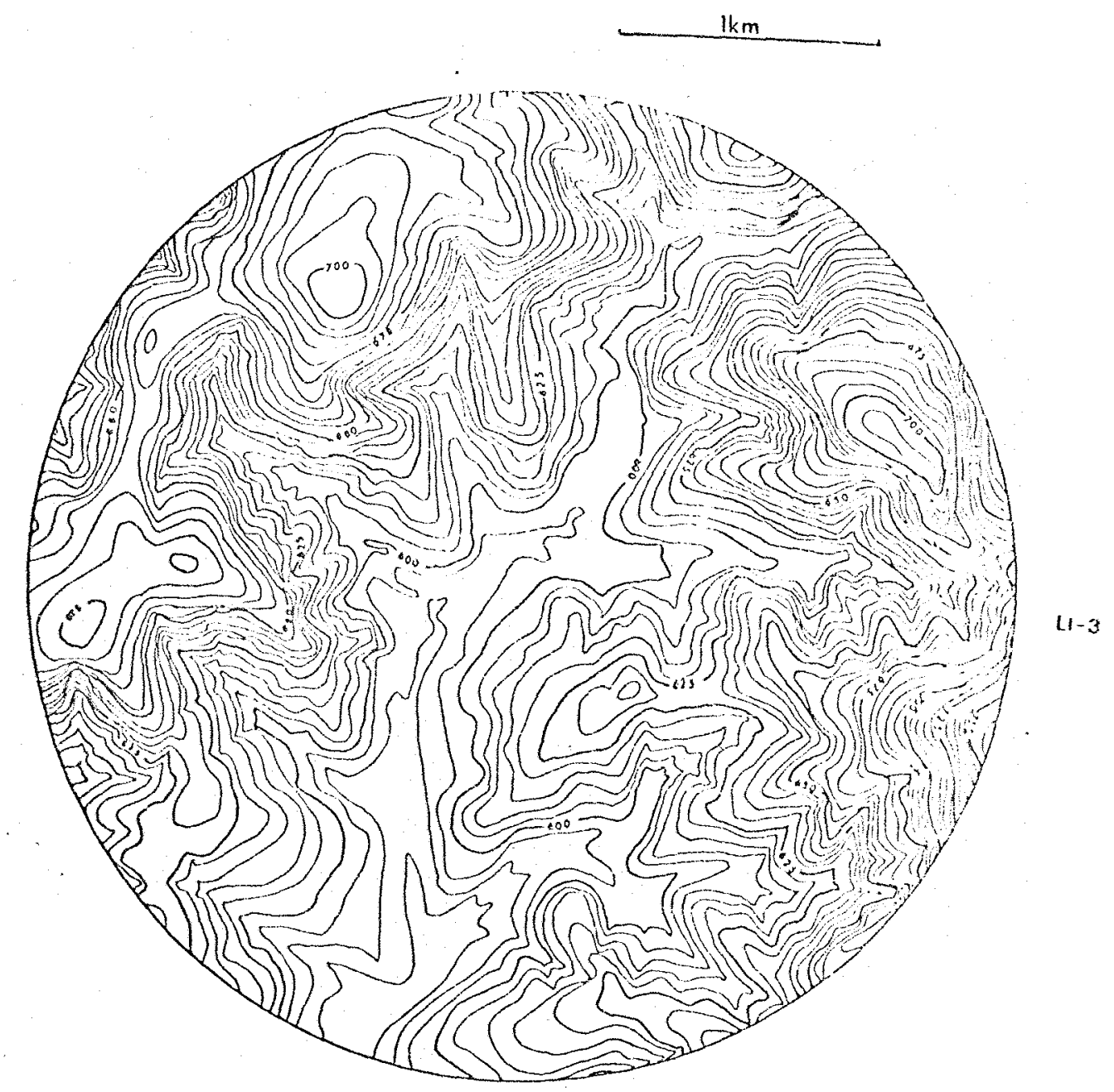

Figura 25 - Anostra Circular, Li-3 $\left(10 \mathrm{~km}^{2}\right)$, do relevo em Litossolo. Escala 1:10.000. 
.94.
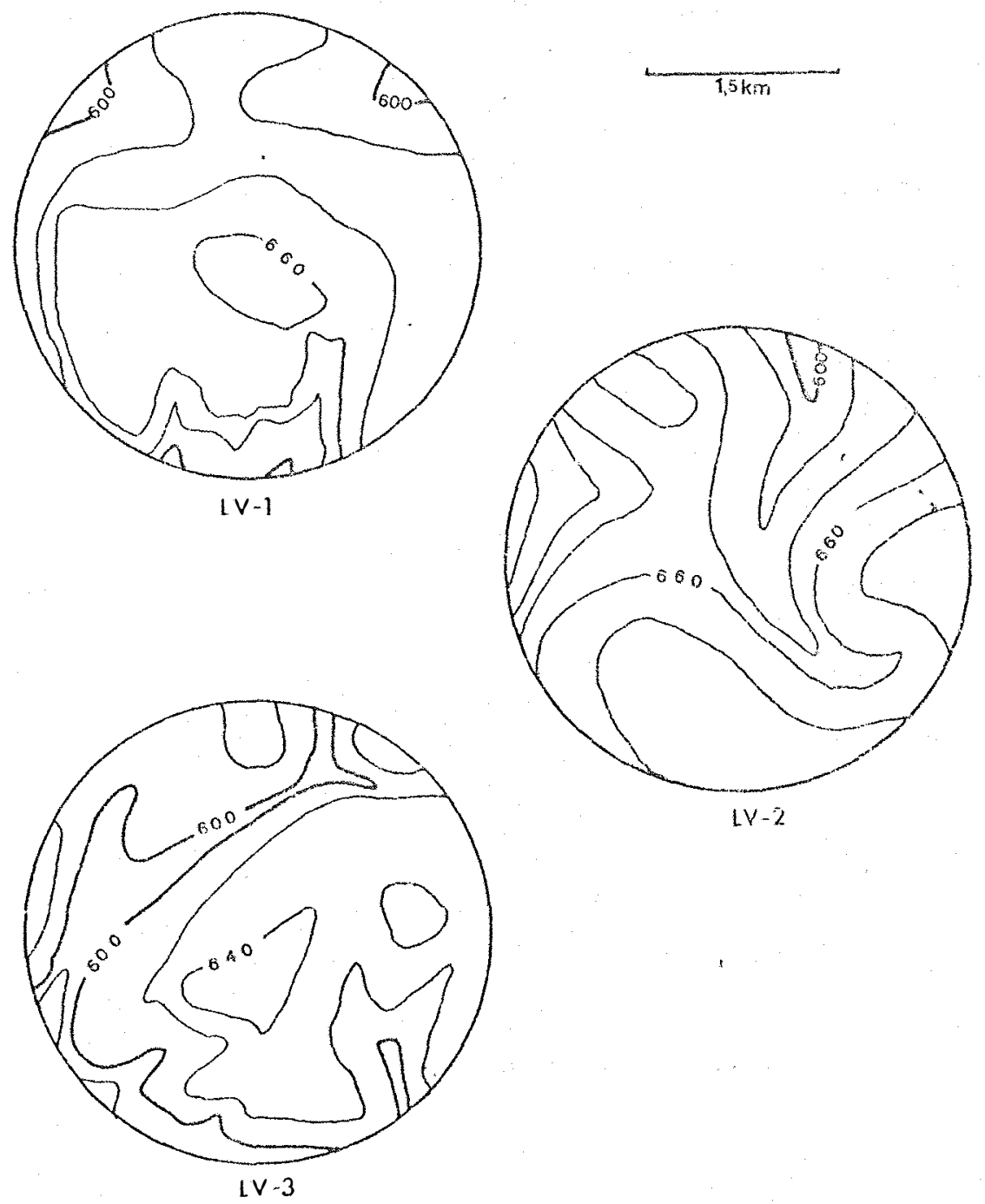

Figura 26 - Amostras Circulares, LV-1, LV-2 e LV-3 (10 km²), do relevo em Latossolo Vermelho-Amarelo. Escala 1:50.000. 


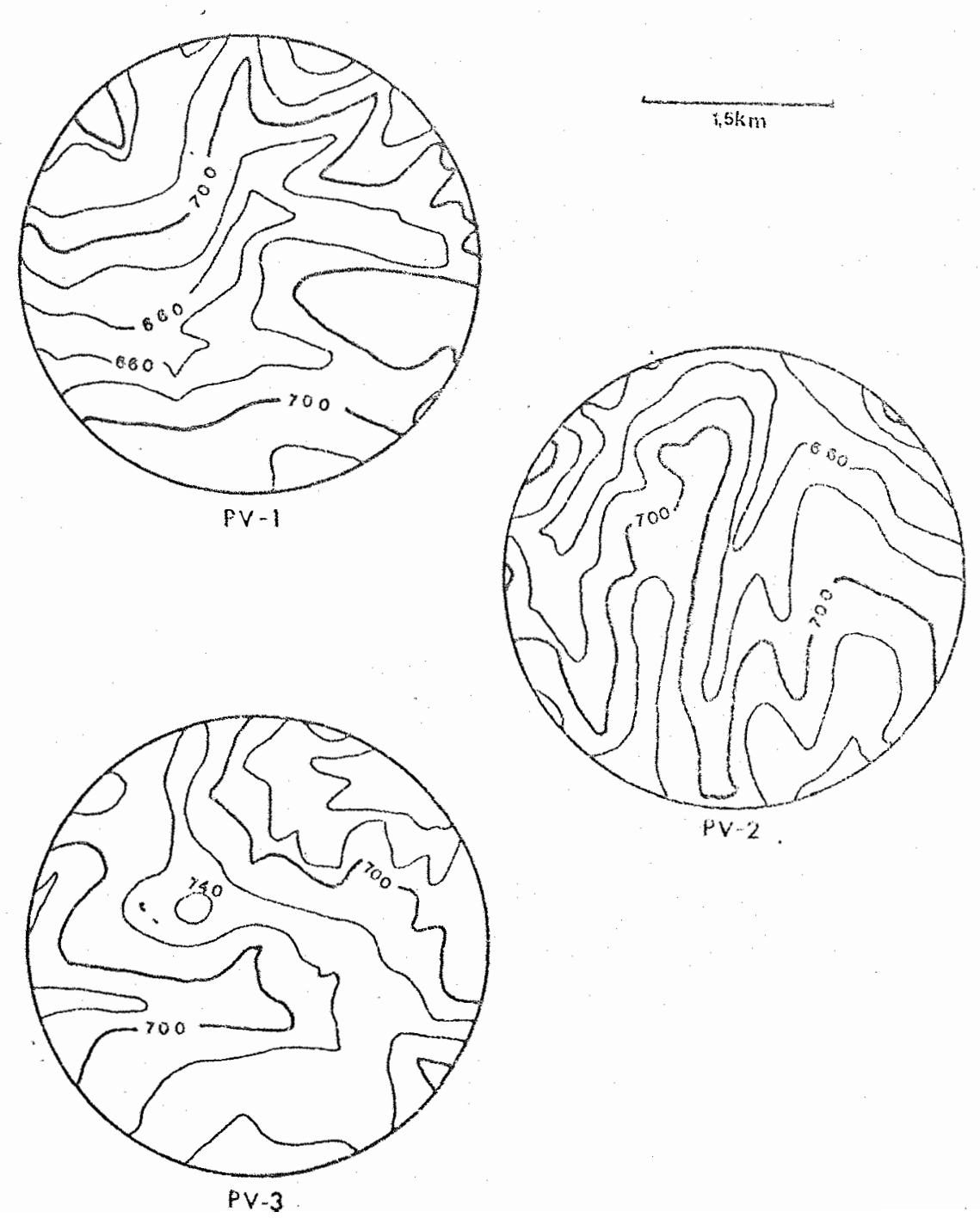

Figura 27 - Amostras Circulares, PV-1, PV-2 e PV-3, (10 km?2), do relevo em Podzölico Vermelho-Amarelo. Escala 1:50.000. 

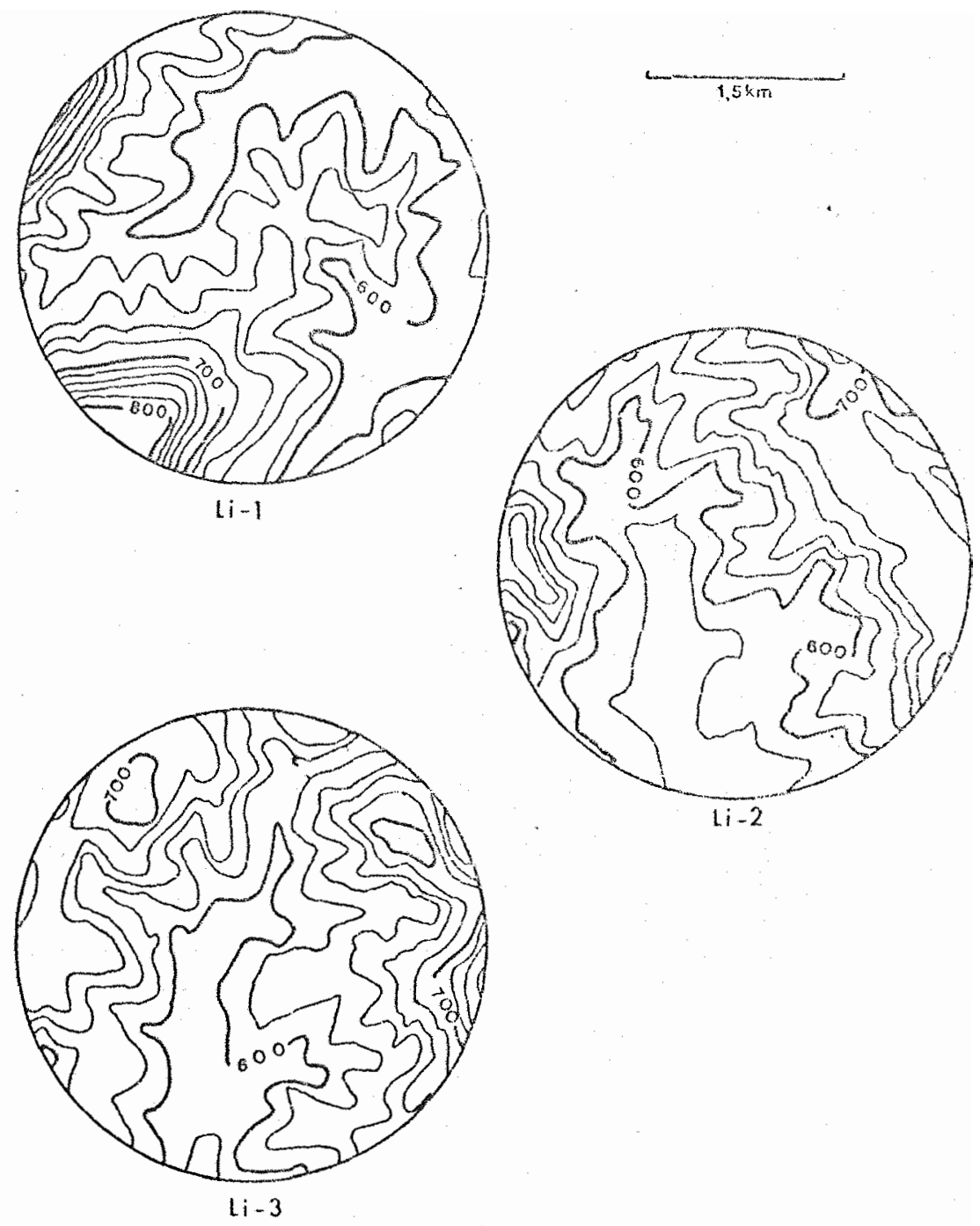

Figura 28 - Amostras Circulares, Li-1, Li-2 e Li-3, $\left(10 \mathrm{~km}^{2}\right)$, do relevo em Litossolo. Escala 1:50.000. 
Tabela 6 - INümero de rios observados em cada orden e o total para as amostras circulares; mëdias e respectivos erros padröes.

\begin{tabular}{|c|c|c|c|c|c|c|c|c|}
\hline \multirow[t]{3}{*}{ SOIO } & \multirow{2}{*}{\multicolumn{2}{|c|}{ ORDEM }} & \multicolumn{3}{|c|}{$\begin{array}{l}\text { Nümero de rios } \\
\text { em cada ordem }\end{array}$} & \multirow{3}{*}{$\begin{array}{l}\text { Média } \\
\text { Padrão }\end{array}$} & & \multirow{3}{*}{$\begin{array}{l}\text { Erro } \\
\text { Média }\end{array}$} \\
\hline & & & \multicolumn{3}{|c|}{ Amostras Circulares } & & & \\
\hline & & & LV-1 & $L V=2$ & $L V-3$ & & & \\
\hline Latossolo & $1 ?$ & & 14 & .4 & 11 & 9,666 & \pm & 2,963 \\
\hline Vermelho & $2 a$ & & 3 & 1 & 5 & 3,000 & \pm & 1,155 \\
\hline \multirow[t]{3}{*}{ Amarelo } & $3 a$ & & 1 & 0 & 2 & 1,000 & \pm & 0,577 \\
\hline & Total & $(N t)$ & 14 & 4 & 11 & 9,666 & \pm & 2,963 \\
\hline & & & $P V-1$ & $\mathrm{PV}-2$ & $P V-3$ & & & \\
\hline Fodzölico & $1 \mathfrak{a}$ & & 79 & 80 & 81 & 80,000 & \pm & 0,577 \\
\hline Vermelho & $2 a$ & & 25 & 22 & 21 & 22,660 & \pm & 1,201 \\
\hline \multirow[t]{4}{*}{ Amarelo } & $3 a$ & & 5 & 5 & 6 & 5,333 & \pm & 0,333 \\
\hline & Total & $(N t)$ & 79 & 80 & 81 & 80,000 & 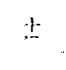 & 0,577 \\
\hline & & & Li-1 & Li-2 & Li-3 & & & \\
\hline & $1 \stackrel{a}{a}$ & & 195 & 253 & 224 & 224,000 & \pm & 16,743 \\
\hline \multirow[t]{3}{*}{ Litossolo } & $2 a$ & & 53 & 79 & 59 & 63,666 & \pm & 7,860 \\
\hline & $3 a$ & & 19 & 19 & 14 & 17,333 & \pm & 1,666 \\
\hline & Total & (Nt) & 195 & 253 & 224 & 224,000 & \pm & 16,743 \\
\hline
\end{tabular}


Tabela 7 - Comprimento total de rios para as amostras circulares; médias e respectivos erros padrões.

\begin{tabular}{|c|c|c|c|c|c|}
\hline & & COMPRTMENTOO & MEDIA & \pm & Erro \\
\hline 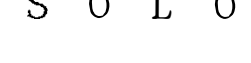 & CIRCUILAR & TOTAJ (Lt) em lon & padrãc & da & Média \\
\hline Latossolo & $L V-1$ & 4,310 & & & \\
\hline Vermelho & $L V-2$ & 5,800 & 6,996 & \pm & 1,972 \\
\hline Amarelo & $L V-3$ & 10,850 & & & \\
\hline Podzölico & PV -1 & 22,800 & & & \\
\hline Vermelho & $\mathrm{PV}-2$ & 23,500 & 23,017 & \pm & 0,242 \\
\hline \multirow[t]{2}{*}{ Anarelo } & PV -3 & 22,750 & & & \\
\hline & $\mathrm{Li}-1$ & 47,250 & . & & \\
\hline \multirow[t]{3}{*}{ Litossolo } & $\mathrm{Li}-2$ & 57,420 & 49,960 & \pm & 3,776 \\
\hline & $\mathrm{Li}-3$ & 45,210 & & & \\
\hline & 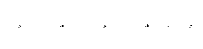 & & & & \\
\hline
\end{tabular}


Tabela 8 - Características descritivas das redes de drenagem, dos rrês solos estudados, segundo LUEDER (1959), tipo ou modelo segundo PARVIS (1950).

\begin{tabular}{|c|c|c|c|}
\hline CADACTEDTCTISAC & IATOSSOLO & PODZOELICO & \\
\hline WAKAL, 1ERISIICAS & VERMELHO & VERMELHO & LITOSSOLO \\
\hline DESCRITIVAS & AMARELO & MARESO & \\
\hline
\end{tabular}

- Grau de Integração pouco integrado

integrado

baixa

Densidade

Grau de

Uniformidade

Orientacão

Grau de controle

Angulo de junção

Argulariclade

Ti.po ou modelo pouco uniforme

pouco orientado

não controlado

aproximadanente retos

baixa

subparalelo mëdis

alta

poluco uniforme pouro mifome pouco orientado pouco oricntado não controlado não controlado retos e agudos retos e agulos baixa baixa dendritico modificado dendritico 
4.3.2.2. Caracteristicas Quantitativas do Padrão de Drenagem

As caracteristicas quantitativas do padräo de dre.nagem, o valor médio e erro padrão da média, para as amostras cir culares representativas dos solos em estudo encontram-se na Tabela 9 .

4.4. CARActeristicas DO RELEVO

4. 1.1. CARACTERISTICAS QUANTITATMVS DOS PMRÂMETROS DE RELEVO

As caracteristicas quanticativas dos parametros de relevo, o valor médio e erro padrão da méda, para as amostras circulares representativas dos solos em estudo encontramse nas Tabelas 10 e 11 . 


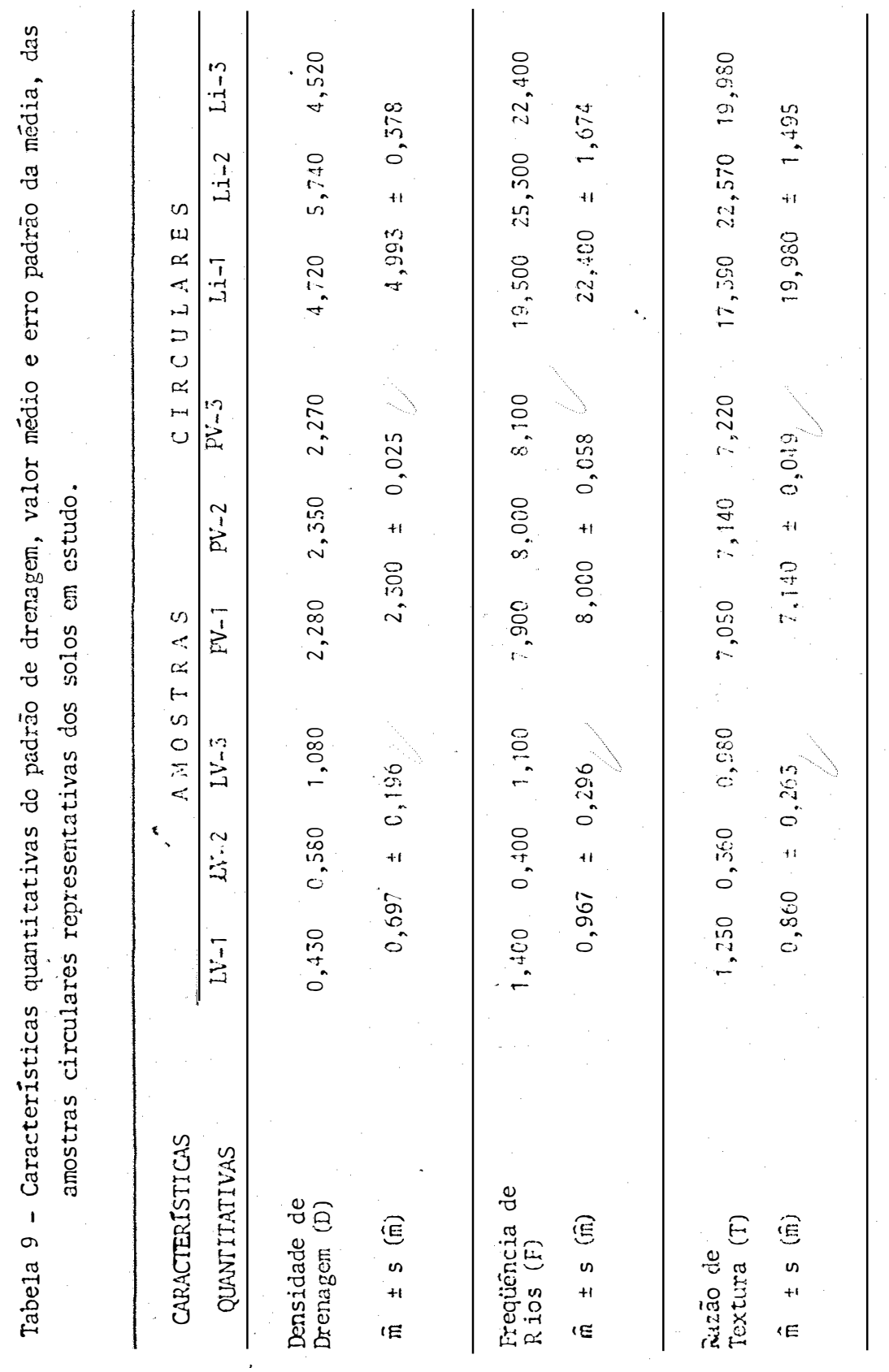




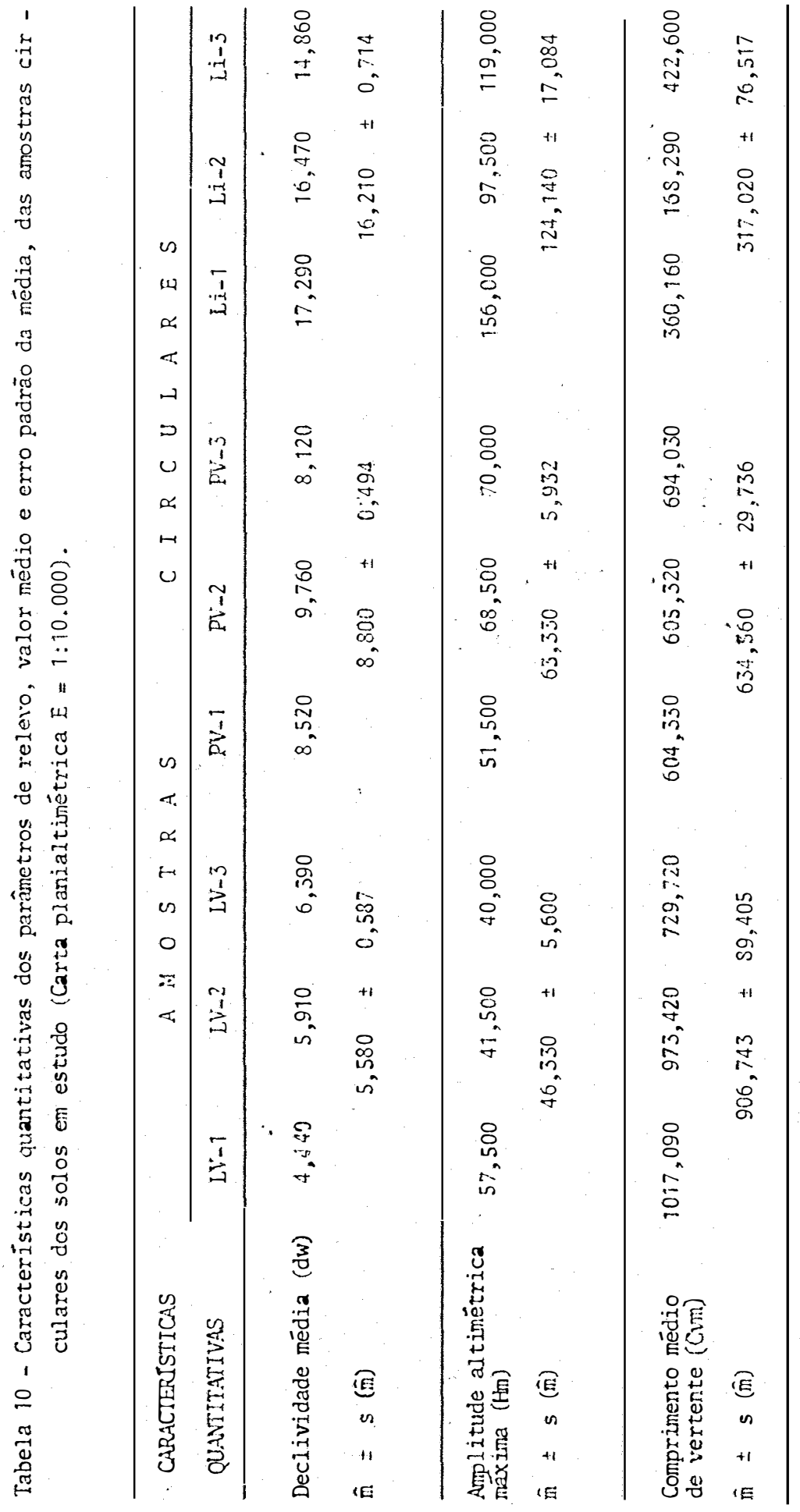




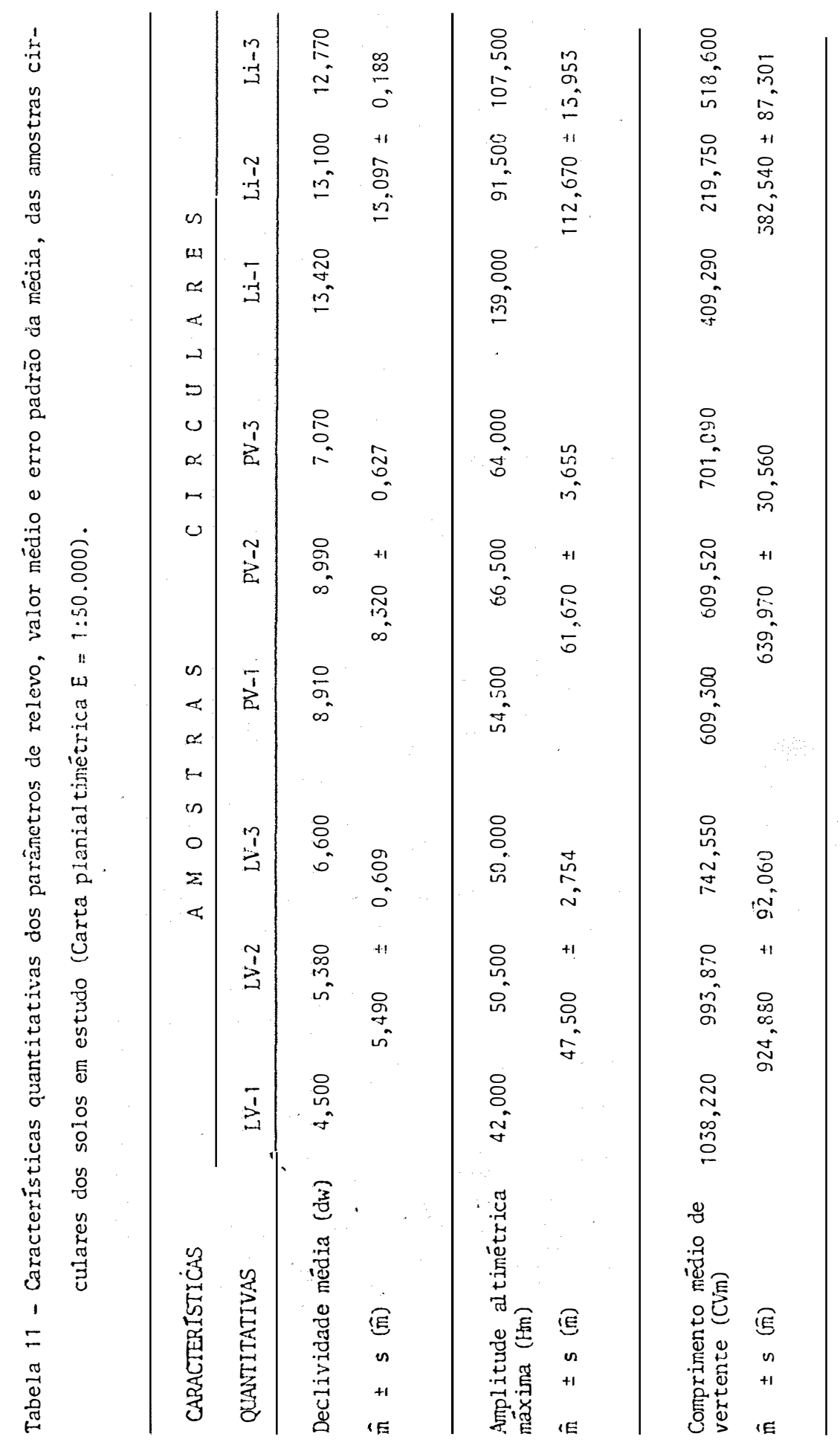


5. DISCUSSÃO DOS RESULTADOS

\subsection{CARActeristicas mas amostras circulares}

\subsubsection{LATOSSOLO VERGELHO-AMARELO}

As figuras 8, 11 e 14 representam, respectiva mente, as amostras circulares da geologia, solo e rede de dre nagem superficial do Latossolo Vermelho-Amarelo.

Analisando as figuras observa-se que existe uma maior correlação entre a rede de drenagem traçada com auxílio da fotografia aérea e o mapa geológico do que com o mapa de so 1os. Isto pode ser exemplificado pelas amostras: LV-1 onde a rede de drenagem, que indica uma inclusão de outro solo, coincide com a ârea que corresponde à Formação Aquidauana; e LV-3 onde os longos rios, típicos dos latossolos, ocorrem na ârea 
correspondente aos depósitos Coluviais, sendo que a rede de drenagem mais ramificada está dentro da ärea da Formação Itara rê. Observa-se também que o mapa de solos não detecta estas di ferenças.

\subsubsection{PODZOOLICO VERMELHO-AMARELO}

Ao se correlacionar as Figuras 9, 12 e 15, que representam as amostras circujares da geologia, solo e rede de drenagem do Podzólico Vermelho-Amareio, observa-use nas amostras PV-1 e PV-2 que a área de ocorrência da Formação pirambóia cor responde, na amostra das redes de drenagem, a uma ärea com poucos rios. As figuras 20 e 21 ajudam na análise, mostrando que

estas áreas correspondem a divisores de ägua. Novamente o mapa de solos não é tão sensível a estas diferenças, como o da geolo gia.

\section{5,1,3, Litossolo}

As Figuras 10,13 e 16 correspondem às amostras circulares da geologia, solo e rede de drenagem do Litossolo. A nalisando-se estas figuras percebe-se que, neste caso, ocorre um maior relacionamento entre os atributos das amostras.

Correlacionando as amostras Li-1, Li-2 e Li-3 da geologia e rede de drenagem, verifica-se que a ārea onde se en- 
contra a Formação Pirambóia, como no caso do Podzólico Verme1ho-Amarelo, corresponde a uma ärea de cotas mais altas (divisores de águal onde ocorre uma maior densidade de rios de primeira ordem. Associando-se as amostras da geologia com as de solo observa-se que também há uma correlação, principalmente nas amostras Li-2 e Li-3 onde a área de oçorrência da Formação Pirambóia se relaciona com as inclusões de Podzólico Vermelho-Amarelo (PV-2).

\subsection{AMOSTRAS CiRCULARES REPRESENTATIVAS DA DRENAgEM E DO RELEVO}

As Figuras 14 a 16 representam as amostras circulares da drenagem que foram obtidas segundo FRANC $\Lambda$ (1968), de Latossolo Vermelho-Amarelo, Podzólico Vermelho-Amarelo e Litosso 1o, respectivamente, a partir da interpretação das fotografias a êreas verticais na escala 1:35.000. Analisando-se as figuras citadas, verificam-se diferenças nas redes de drenagem tracadas, tanto no aspecto de tipo ou modelo como na densiaade das mesmas.

As Figuras 17 a 25 e 26 a 28 , que correspondem às amostras circulares representativas do relevo, extraídas das cartas planialtimétricas na escala $1: 10.000$ e $1: 50.000$, respec 
tivamente, mostram claramente as diferenças na posição topogrā fica dos três solos estudados. Mostram tambëm as diferenças de detalhes entre as cartas planialtimétricas utilizadas neste tra balho.

\subsection{ANALISE dAS REDES DE DRENAGEM}

\section{3 .1 . COMPOSICAO DA REDE DE DRENAGEM}

\subsubsection{Número de ríos}

Como mostra a Tabela 6 , o número total de rios, assim como os rios de 1 ạ, 2 ạ e $3 a ̣$ ordens, apresentaram uma tendência a aumentar em proporção inversa ao valor da relaşão infiltração/defiúvio e na razão direta da erodibilidade dos solos, con cordando com as observações de HORTON (1945), LUEDER (1959), DE METRIO (1977), ANGULO FJLHO (1981) e MANECHINI (1981). Estas ob servações concordam com as de FREIRE e PESSOTTI (1974) e LOMBARDI NETO e BERTONI (1975) que, estudando solos do Estado de São Paulo, concluíram que os Latossolos são mais resistentes à erosão do que os solos Podzólicos.

5.3.1.2. Comprimento total de rios

Da mesma forma, na análise da Tabela 7 , o compri mento total de rios apresentou a tendência de aumentar, em proporção inversa ao valor da relação infiltração/deflúvio e na ra 
zão direta da erodibilidade dos solos, concordando novamente com os autores citados no item anterior.

\subsubsection{ANÁLISE DAS CARACTERÍSTICAS DO PADRÃO DE DRENAGEM}

\subsubsection{Características descritivas do padrão de drenagem}

A análise descritiva do padrão de dreriagem, Tabela 8, elaborada com os elementos propostos por PARVIS (1950) e LUEDER (1959), apresentou valor limitado na diferenciação entre os solos estudados, concordando portanto com as observações efetuadas por MANECHINI (1981) e VETTORAZZI (1985); is to é devido à maneira subjetiva com que estas características são estabelecjdas, e confirmam as observaçöes de HORTON (1945), STRAH LER (1957) e FRANÇA (1968).

A maior diferenciação entre os solos estudados, no tocante às características descritivas, foi obtida na densidade: baixa para Latossolo Vermelho-Amarelo, média para Podzólico Vermeiho-Amarelo e alta para Litossolo; no grau de integração obteve-se pouco integrado para Latossolo Vermelho-Amarelo e integrado para os outros dois solos; quanto ao tipo ou modelo também hou ve diferença entre o Latossolo Vermelho-Amarelo, subparalelo, pas sando a dendrítico para os demais solos. Para as outras características não houve distinção entre os três solos.

Fica evidenciado, portanto, que essa caracteriza- 
ção é muito subjetiva e deve ser completada com indices numéricos, mais consistentes e reproduzíveis, como sugerem DEMÉTRIO (1977) e ANGULO FILHO (1981).

5.3.2.2. Características quantitativas do padrão de drenagern

A caracterização quantitativa foi efetuada através dos indices densidade de drenagem, freqüência de rios e razão de textura.

Estes indices não foram submetidos a nenhum teste estatístico, paramétrico ou não-paramétrico, devido à pouca a mostragem e falta de aleatoriedade, que foi causada pela necess dade de se trabalhar em áreas que possuíssem a carta.de solos do levantamento semidetalhado do Estado de São Paulo, a carta planialtimétrica na escala 1:10.000 do levantamento cartográfico do Estado de São Paulo e a carta planialtimétrica na escala de 1:50.000 publicada pelo IBGE. Deste modo optou-se por apresentar os dados como constam da Tabela 9, calculando-se as médias e os erros padrões da média e elaborando o gráfico da Figura 29, que é um resumo dos índices de drenagem e que mostra perfeitamente que existem diferenças de valores obtidos para os três solos estudados .

Além disso, durante a elaboração deste trahaıho foi tentada a utilização dos testes não-paramétricos de Friedmann e Kruskal Wallis e das Comparações Múutinlas, que não foi sensivel para dí 
ferenciar os três solos, concordando com as observações de MANECHINI (1981) e VETTORAZZ I (1985).

Portanto, os resultados obtidos concordam com SOUZA (1975), que afjrma que os índices numéricos obtidos em amostras circulares servem para diferenciar solos.

No entanto, as afirmativas de HORTON (1945) e STRAHLER (1964), de que haveria necessidade de utilizar dois índices, a densidade de drenagem e a freqüencia de rios conjuntamente, não foi confirmada, pois quaisquer dessas característi.. cas, tomadas isoladamente, serve para diferenciar os solos estudados

Além disso, vārios pesquisadores, entre eles FADEL (1972), SOUZA (1975), KOFFLER (1976b), CARVALHO (1977), DEMETRIO (1977), ANGULO FILHO (1981) e VALERIO FILHO (1984), verificaram a grande eficiência do ínàice densidade de drenagem na diferenciação entre solos.

A razão de textura também ou ser um bom índi ce, concordando com as observações de SOUZA (1975) e KOFFLER (1976a), autores que estenderam a determinação deste índice às a mostras circulares, utilizadas posteriormente por DEMETRIO (1977), NOGUEIRA (1979), POLITANO.(1980), ANGULO FILHO (1981) e MANECHINI $(1981)$ 
.111.

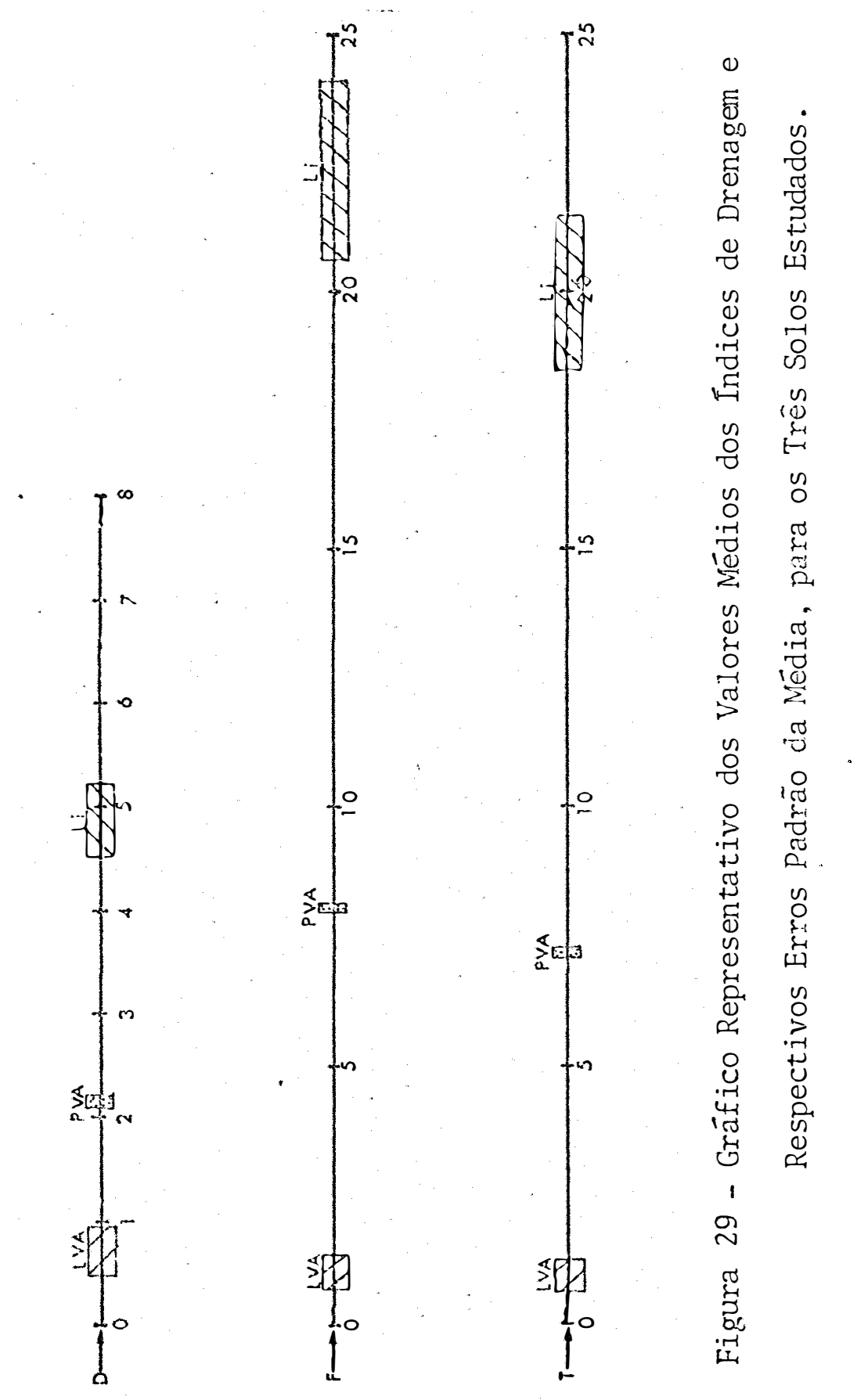


.112 .

\subsection{ANÁlise DAS CARACTERÍSTICAS D RELEVO}

\subsubsection{CARACTERÍSTICAS QUANTITATIVAS DOS PARÂMETROS DE RELEVO}

Os parâmetros de relevo foram pesquisados por a 1 guns autores entre eles MARCHETTI(1969), POLITANO (1980), LEÃO (1983) e VALERIO FILHO (1984), os quais, atravês de índices relativos aos atributos do rèlevo têm demonstrado a contribuição destes na diferenciação entre solos.

Dentre os autores citados, VALERIO FILHO (1984)

utilizou três indices, declividade média, relevo local médio (ou amplitude altimétrica máxima) e comprimento médio da vertente, pos síveis de serem obtidos através de amostras circulares, de $10 \mathrm{~km}^{2}$ delineadas sobre cartas planialtimétricas.

No presente estudo, os três indices citados foram determinados para cada amostra circular dos três solos estudados e obtidos das cartas planialtimétricas em escala 1:10.000 e 1:50.000, como mostram as Tabelas 10 e 11 .

Pelos mesmos motivos citados anteriormente, só foram determinadas as médias e os erros padrões das médias para os três parâmetros de relevo estudados. Estes valores encontram-se resumidos na Figura 30.

\subsubsection{Declividade média}

Os resultados encontrados, Tabelas 10 e 11 e Fi- 


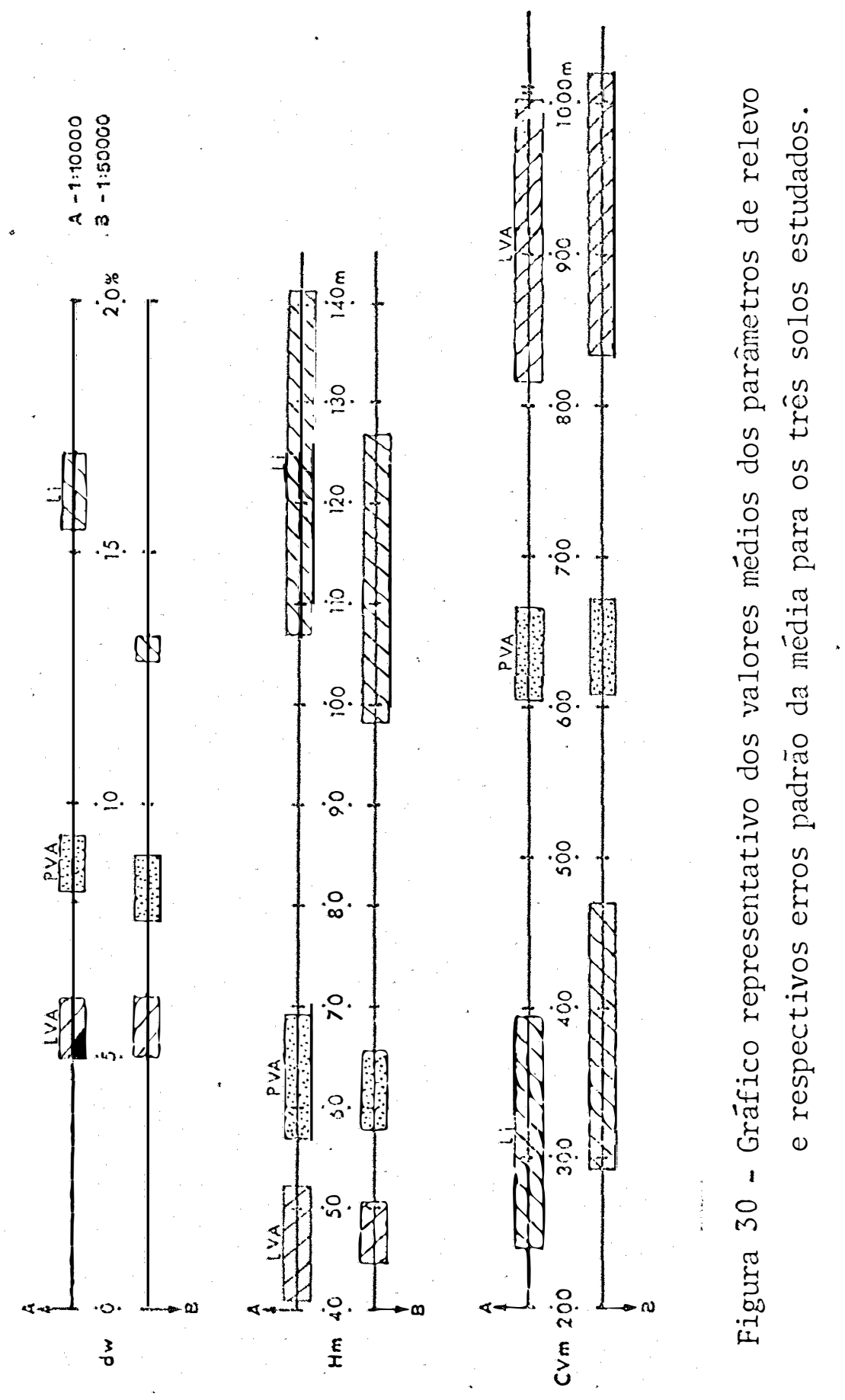


gura 30 , indjcam que existem diferenças entre os três solos anali sados (Latossolo Vermelho-Amarelo, Podzólico Vermelho-Amarelo e Litossolo), e que a razão destas diferenças são as condições da relação infiltração/deflúvio, permeabilidade e resistência dos materiais de origem, que estariam correlacionados com as declividades médias determinadas.

Os resultados obtidos concordam com WONG et alii (1971) e demonstram a importância deste parâmetro do relevo para diferenciação dos solos. AVERBECK e SANTOS (1969), CRISTOFOLETTI (1980), KOFFLER (1982) e VALERIO FILHO (1984), observaram que a variação de declividade geralmente implica na variação de solo, o que concorda com os dados observados.

HORTON (1945), STRAHLER (1957), SMITH e AANDAHL (1957) mencionaram o relacionamento entre as caracteristicas da rede de drenagem e as condições topográficas, donde as variações no comportamento da rede refletem alterações das condições topogräficas de uma região, observação esta que foi confirmada no pre sente trabalho.

\subsubsection{Amplitude altimétrica máxima}

Examinando as Tabelas 10 e 11 e Figura 30 , verifica-se que houve diferença entre os três solos estudados (JatossoloVermelho-Amarelo, Podzólico Vermelho-Amarelo e Litossolo), o que evidencia a existência de relevos diferentes, concordando com os resultados encontrados por BRIDGES e DOORNKAMP (1963), AMARAL e AUDI (1972), LEAO (1983) e VALERIO FILHO ( 1984). 
Os resultados discordam de POLITANo (1980) que não encontrou diferença quanto a este indice entre os solos por $\underline{\text { e }}$ le estudado. Isto talvez seja devido à semelhança quanto às carac terísticas morfológicas, pois os dois solos, Podzolizados de Lins e Marilia, variação Marília e Solos Podzólicos Vermelho-Amarelo, variação Laras, apresentam horizonte B textural.

\subsubsection{Comprimento mëdio das vertentes \\ Os resultados encontrados, Tabelas 10 e 11 e Fi-} gura 30 , mostram que o comprimento médio da vertente também foi $\varrho$ ficiente na distinção entre os solos estudados, discordando parcial: mente de VALERIO FILHO (1984), onde o indice foi eficiente somente para discriminar o Litossolo Roxo do Latossolo Vermelho-Amarelo textura argilosa/mé dia.

Este indice foi introduzido, por VALERIO FILHO (1984) no sentido de testar sua eficiência na diferenciação de solos, pois segundo CHRISTOFOLETTI (1980), quanto maior a densidade de drenagem em una área com relevo semelhante, menores e mais inclinadas serão as vertentes, que é o caso do Litossolo em estudo.

Ainda para CHRISTOFOLETTI (1980), as vertentes constituem partes integrantes das bacias hidrográficas e não podem ser descritas de modo integral sem que se faça consideração das relações entre elas e a rede hidro gráfica, pois ê impossível considerar as vertentes e os rios como entidades separadas. Estas considerações são válidas para os três parâmetros de relevo analisados. 


\title{
5.5. ANÁlISE DOS RESULTADOS DOS PARÂHETROS DE RELEVO OBTIDOS DE CARTAS PLANIALTIMÉTRICAS EM ESCALAS DIFERENTES
}

\author{
Como sugeriram ANGULO FILHO et alii. (1983) e DEMETRIO
} (1984), a delimitação das classes de declive serve de parâmetro pa ra a comparação entre cartas planialtimétricas. Portanto, para o presente trabalho em que existem três classes de declive, como mostram as Tabelas 10 e 11 e a Figura 30, e que correspondem aos três solos estudados, também é possível comparar os resultados dos parâmetros de relevo que foram obtidos de cartas planialtimétrica em escalas diferentes.

\section{$5,5,1$, DECLIVIDADE MÉDIA}

O parâmetro declividade média, obtido segundo KOFFLER (1982), foi um indice eficiente na diferenciação dos solos estudados, como já foi demonstrado anteriormente. No entanto, quando se comparam os valores obtidos das cartas planialtimétricas em escalas diferentes, Tabelas 10 e 11 e Figura 30, observa-se que os resul tados permanecem coerentes para o Latossolo Vermelho-Anarelo e Podzólico Verme lho-Amarelo, e que diferem no litossolo. Isto se deve à capacidade das duas cartas em representar o relevo. Assim, tem-se que, a carta planialtimétrica $1: 10.000$ (IGC) possui equiidistância vertical igual a $5 \mathrm{~m}$ e a carta planialtimétrica $1: 50.000$ (IBGE) possui equiidistancia vertical de $20 \mathrm{~m}$; portanto, apesar do método de determinação da declividade média sugerido por KOFFLER (1982) possuir um fator de correção para eqüidistância vertical, ele não foi eficiente 
no caso de um relevo mais acidentado onde o número de curvas de nível é muito grande.

A. exp̣]icação provável é que, por possuir equiidistância ver tical igual a $20 \mathrm{~m}$, a carta nlanialtimétrica de escala 1:50.000 não representa com detalhe o relevo existente nas äreas mais acidentadas, o que não acontece na carta planialtimétrica de escala $1: 10.000$, onde a equidistância vertical de $5 \mathrm{~m}$ fornece um maior detalhamento do relevo da ärea em estudo.

No entanto, isto não significa imprecisão da car ta, pois ambas dentro de suas respectivas categorias, estão dentro dos padrões de precisão normalmente aceitos.

\subsubsection{AMPLITUDE ALTIMÉTRICA MAXXIMA}

Este indice, obtido conforme CHRISTOFGLETTI (1980) e VALERIO FILHO (1984), também apresentou a mesma tendència nos resultados, Tabelas 10 e 11 e Figura 30, que a declividade média. Isto foi devido, como foi explicado anteriormente, pela maior capacidade da carta planialtimétrica na escala $1: 10.000$ de representar com detalhe o relevo.

\section{$5,5,3$, COMPRIMENTO MÉDIO BAS VERTENTES}

Os resultados deste índice, que constam das Tabe las 10 e 11 e Figura 30 , foram obtidos segundo sugere VALERIO 
FILHO (1984). A comparação entre os resultados obtidos das cartas planialtimétricas em escalas diferentes, permite que se façam as mesmas considerações jâ elaboradas nos ítens anteriores e, desta forma, confirmar que houve uma diferença entre os parâmetros de relevo obtidos na área de relevo mais acidentado (Litossolo), devido à maior capacidade de representação do relevo das zartas planialtimétricas em escala 1:10.000 (equiidistância vertical de $5 \mathrm{~m}$ ) em relação às cartas nlanialtimétricas em escala 1:50.000 (e qüidistância vertical àe $20 \mathrm{~m}$ ). 


\section{CONCLUSÕES}

Os resultados obtidos, analisados e interpreta dos, permitiram tirar as seguintes conclusões:

- os indices de drenagem utilizados (densidade de drenagem, freqüencia de rios e razão de textura), foram eficientes na diferenciação dos solos estudados;

- os Índices de relevo (declividade média, ampli tude altimétrica máxima e comprimento médio das vertentes), também foram eficientes na discriminação dos três solos estudados;

- as cartas em maior escala e que têm maior capa cidade de detalhar o relevo das área em estudo são mais confiáveis para caracterizar quantitativamente o relevo, além disto, para diferenciar solos que se encontram em relevo acidentado semelhante, a utilização das cartas planialtimétricas que deta- 
tham mais o relevo fornecerão resultados mais dignos de confian-.. ça;

- as caracteristicas qualitativas das redes de drenagem não foram eficientes na diferenciação dos três solos es tudados;

1 - a caracterização quantitativa e anâlise dos

- indices de drenagem e relevo, utilizando-se apenas as nuêdias e erro padrão das médias, foi suficiente para mostrar diferenças on tre os solos analisados. 


\section{LITERATURA CITADA}

ALMEIDA, F.F.M., 1964. Os fundamentos Geológicos do Rolevo Paulista. (IGEOG Série Teses e Monografias, 14) São P̉aulo, USP, Instituto de Geografia, $110 \mathrm{p}$.

AMARAL, A.Z. e R. AUDI, 1972. Fotopedologia. In: MONiz, A.C. coord. Elementos de Pedologia. São Paulo, Editora da USP, p. $429-442$.

ANGULO FILHO, R., 1981. Variacões de Caracteristicas da Rede de $\underline{\text { Drenagem em Função das Fotografias Aéreas Verticais Obtidas }}$ em Epocas Diferentes. Dissertação de Mestrado. Piracicaba, ESALQ/USP, $128 \mathrm{p}$. 
ANGULO FILHO, R.; DEMETRIO, V.A.; VETORAZZI, C.A., 1983. Avaliação da Precisão do Método de Determinação das Curvas de Nível pela Restituição Aerofotogramétrica. O SOLO. Piracicaba, $\underline{75}(2): 44-50$

AVERBECK, H. e SANTOS, R.D., 1969: Manual de Fotointerpretação para Solos (1ạ. Aproximação). Rio de Janeiro, Ministério da Agricultura, $33 p$.

AVERY, T.E., 1977. Interpretations of Aerial Photographs.. 3ạ ed. Minneapolis, Minnesota, Burgess Publishing Company, 392p.

BASTOS; A., 1966. Soils Mapping and Aerial Photography on Soils Conservation. In: CONGRESSO PANAMERICANO DE CONSERVAÇÃO DO Solo, 1., São Paulo, Atas. São Paulo, Secretaria da Agricultura, p. 383-388.

BELCHER, D.J., 1945. The engineering significance of soil patterns. Photogram. Engineer, 11: 115-148

BLOOM, A.L., 1970. Superfície da Terra. Trad. e coment. por S.Petri e R. Ellert. São Paulo, Editora Edgard Blücher e Editora da USP. $184 \mathrm{p}$.

BOMBERGER; E.H. e H.W. DILL Jr., 1960. Photo Interpretation in Agriculture. In: AMERICAN SOCIETY OF-PHOTOGRAMMETRY - Manual. of Photografic Interpretation. Washington, p.561-632 
BRIDGES, E.M. e DOORNKAMP, J.C., 1963. Morphological Mapping and the Study of Soil Patterns. Geography, 48(1):175-181.

BURINGH, P., 1960. The Applications of Aerial Photographs in Soil Surveys. In: AMERICAN SOCIETY OF PHOTOGRAMMETRY. Manual of Photographic Interpretation. Washington, Cap. 11, p.633-666.

CAMPOS, H., 1983. Estatística Experimental Não-Paramétrica. 4a ed. Piracicaba. Escola Superior de Agricultura "Luiz de Queiroz", Departamento de Matemática e Estatística, 349p.

CARVALHO, W.A, 1977. Fotointerpretação de Bacias Hidrogräficas com Amostras Circulares de Redes de Drenagem de Solos com Horizonte B Textural. Piracicaba, ESALQ/USP. 126p. (Tese de Doutoramento)

CHRistofoletti, A., 1969. Anālise Morfométrica das Bacias Hidrogräficas. Notícias Geomorfológicas, Campinas, 9 $:$ 35-64

CHRISTOFOLETTI, A., 1980. Geomorłologia. 2ạ ed. São Paulo, Ed. Edgard Blücher Ltda. 188p.

COWELL, R.N., 1952. Photographic Interpretation for Civil Purposes. In: AMERICAN SOCIETY OF PHOTOGRAMMETR. Manual of Photogrammetry. 2a ed. Washington, p.535-602. 
CURTIS; L.F., DOORNKAMP, J.C. e GREGORY, K.J., 1965. The Desciption of Relief in Field Studies of Soils. Journal Soil Science, 16(1): $16-30$

GEMETRIO, V.A., 1977. Variação de Características de Redes de Drenagem em Função áa Escala das Fotografias Aéreas Verticais. Piracicaba, ESALQ/USP. 107p. (Dissertação de Mestrado)

DEmEtrio, V.A., 1984. Estudo do Deslocamento das Curvas de Nível Restituídas com Base nos Métodos de Apojo, Geométricos e Trigonométrico. Piracicaba, ESALQ/USP. 101p. (Tese de Livre Docên.cia )

DUNBAR, R.A., 1969. Problems of Interpretation in Tropical Regions. In: Aerial Photographic Interpretation: Principles and Applications. New York, McGraw-Hill, p.426-427.

ESPINDOLA, C.R. e GARCIA; G.J., 1978. Interpretação Fotogrä́fica de Redes de Drenagem em Diferentes Categorias de Solos. Notícia Geomorfológica, 18(35):71-94

FADEL, H., 1972. Fotointerpretação de Bacias e de Redes de Drenagem de Três Séries de Solos da Fazenda Ipanema, Município de Araçoiaba da Serra (SP). Piracicaba, ESALQ/USP. 92p. (Dissertação de Mestrado) 
FRANÇA, G.V., 1968. Interpretação Fotogräfica de Bacias e de Redes de Drenagem Aplicada a Solos da Região de Piracicaba. Piracicaba, ESALQ/USP. 151p. (Tese de Doutoramento).

GREIRE, J.C., 1977. Fotointerpretação de redes de drenagem dos Três solos da região de Alpinópolis, Minas Gerais. Piracicaba, ESALQ/USP. 136p. (Tese de Doutoramento).

FREIRE, O. e J.E.S. PESSOTTI, 1974. Erodibilidade dos solos do Estado de São Paulo. Anais da E.S.A. "Luiz de Queiroz", Piracicaba, 31:333-350.

FROST, R.E., 1960. Photo Interpretation of Soil. In: AMERICAN SOCIETY OF PHOTOGRAMMTRY. Manual of Dhotographic Interpretatios. Washington, Cn. 5, p. 343-402.

GGARCIA, G.J., 1982. Estudos do Solo e Relevo. In: Sensoriamento.

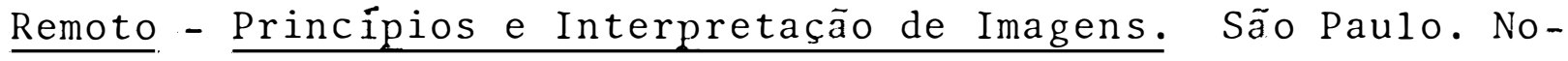
be1, Cap. 7, p.194-204.

GEVAERD; I., 1974. Parâmetros Fotoanalíticos de Três Unidades de Solo da Região Nordeste Paranaense. Piracicaba, ESALQ/USP. 110p. (Dissertação de Mestrado).

GOOSEN, D., 1968. Interpretacion de Fotos Aereas y su Importancia en Levantamiento de Suelos. Roma, Organizacion de las Naciones Unidas para la Agricultura y la Alimentacion. 58p. (Boletim sobre suelos, 6). 
HENRIKSEN, S.W., 1980. Field Surveys for Photogrammetry. In: AMERICAN SOCIETY OF PHOTOGRAMMETRY. Manual of Photogrammetry. 4a ed. Cap.8, p.413-452.

HILWIG, F.W. e KARALE, R.L., 1973. Physiographic Systems and Elements of Photo Interpretation as Applied to Soil Survey in the Ganges Plain. Journal Indian Society Soil Science, 21(2): . 205-212.

HORTON, R.E., 1945. Erosional Development of Streams and Their Drainage Basins Hydrolphysical Approach to Quantitative Morphology. Bul. Geol. Soc. Amer. 56: 275-370.

KOFFLER, N.F., 1976a. Utilização de Imagens Aerofotográficas e Orbitais no Estudo do Padrão de Drenagem em Solos Originados no Arenito Bauru. São José dos Campos, SP. INPE. 167p. (Dissertação de Mestrado)

KOFFLER, N.F., 1976b. Análise Aerofotográfica da Influência da Area de Amostragem Circular na Caracterização Quantatitiva do Padrão de Drenagem. São José dos Campos, SP. INPE. 20p.

KOFFlER, N.F., 1982. Análise de Relevo a Partir de Indices de Drenagem Obtidos com Fotografias Aéreas. Boletim de Geografia Teorética, 12 $(23 / 24): 69-76$. 
LEÃO, S.R.F., 1972. Interpretação Fotográfica dos Padrões de Drenagem Desenvolvidos em Dois Solos do Distrito Federal. Piracicaba, ESALQ/USP. 100p. (Dissertação de Mestrado).

LEÃO, S.R.F., 1983. Interpretação Fotográfica de Características do Relevo e da Drenagem em Dois Solos do Distrito Federal. Tese de Doutoramento. Piracicaba, ESALQ/USP, $166 \mathrm{p}$.

LOMBARDI NETO, F. e J. BERTONI, 1975. Erodibilidade de Solos Paulistas. Campinas, Instituto Agronômico, $12 \mathrm{p}$. (Boletim Têcnico, 27).

LUEDER, D.R., 1959. Aerial Photographic Interpretation Principles and Applications. New York, McGraw-Hill. 462p.

MANECHINI; C., 1981. Utilização de Fotografias Aéreas na Comparação de Sistemas de Drenagem de Três Solos da Região de TambaūSP. Dissertação de Mestrado. Piracicaba, ESALQ/USP, $133 p$.

MARCHETTI, D.A.B., 1969. Fotointerpretação de Atributos de Relevo Aplicada a Solos da Região de Piracicaba. Piracicaba, ESALQ/USP. 58 p. (Tese de Doutoramento).

MONTOYA, J.A., 1983. Interpretacion de Imagenes LANDSAT para el Mapeo de Suelos Bases para una Metodologia. Revista CIAF, $\underline{8}(1)$ : $201-233$ 
NOGUEIRA, F. de P., 1979. Utilização de Fotografias Aéreas em Três Escalas no Estudo de Redes de Drenagem em I)iferentes Unidades de Solo. Piracicaba, ESALQ/USP. 110p. (Dissertação de Mestrado).

OLIVEIRA, J.B. de; ALFONSI, R.R.; PEDRO JUNIOR, M.J., 1975 . Regimes Hídricos e Térmicos dos Solos do Estado de São Paulo. In: CONGRESSO BRASILEIRO DE CIENCIA DO SOLO, Campinas. p.359.362.

OLIVEIRA, J.B. de; MENK, J.R.F.; BARBIERI, J.L.; ROTTA, C.L.; TREMOCOLDI, W., 1982. Levantamento Pedológico Semidetalhado do Estado de São Paulo: Quadrícula de Araras. Bol. Técn. Inst. Agron., Campinas, Vol. 71, 180p.

OLIVEIRA, J.B. de e PRADO, H. do, 1984. Levantamento Semidetalhado do Estado de São Paulo: Quadrícula de São Carlos. Bol. Técn. Inst. Agron., Campinas, Vol. 98, 188p.

PARVIS, M., 1950. Drainage Pattern Significance in A'irphoto Identification of Soils and Bedrocks. Photogrammetry Engineering, 16(3):387-408, Jun.

POLITANO, W., 1980. Estudo Fotointerpretativo sobre a Morfometria das Areas de Dois Solos Podzólicos Vermelho-Amarelo. Piracicaba, ESALQ/USP, 169p. (Tese de Doutoramento) 
QUACKENBUSH Jr., R.S., 1960. Development of Photointerpretation.

In: AMERICAN SOCIETY OF PHOTOGRAMMTRY. Manual of Photographic Interpretation. Washington, Cap. 1, p. 1-18.

QUEIROZ NETO, J.P., 1978. Les Problemes de L'erosion Acceleree dans L'Etat de São Paulo. Bresil. Separat da Geo-Eco-Trop., $2: 205-220$.

RABBEN, E.L., 1960. Fundamentals of Photointerpretation. In: AMERICAN SOCIETY OF PHOTOGRAMMETRY. Manual of Photographic Interpretation. Washington, Cap.3, p.99-186.

RAY, R.G., 1963. Fotografias Aéreas na Interpretação e Mapeamento Geológicos. Tradução de Jesuíno Felicíssimo Jr. São Paulo, Instituto Geogräfico e Geológico. São Paulo. 163p.

RAY, R.G.; W.A. FISCHER, 1960. Quantitative Photography: A Geologic Research Toll. Photogrammetric Engineering, 26(1):143150 , Mar.

RICCI, M.; S. PETRI, 1965. Princípios de Aerofotogrametria e Interpretação Geológica. São Paulo, Editora Nacional, 226p.

ROURKE, J.D. e AUSTIN, M.E., 1951. The Use of Airphotos for Soi.1 Classification and Mapping in the Fields. Photogram. Eng. Washington, 17:738-741.

SCHOBBENHAUS, C.; CAMPOS, D.A.; DERZE, G.R.; ASMUS, H.E., 1984. Geologia do Brasil. Brasilia, Departamento Nacional de Produção Mineral. $501 \mathrm{p}$. 
SILVA, L.C.F., 1977. Fotointerpretação de Redes de Drenagem de Dois Solos do Município de São Pedro (SP). Piracicaba, ESALQ/USP. 114p. (Dissertação de Mestrado)

SIMONSON, R.W., 1950. Use of Aerial Photographs in Soil Surveys. Photogrammetric Engineering, 16: 308-668.

SMITH, K.G. 1950. Standards for Cradind Texture of Erosional Topography. Amer. J. Sci, , 248: 655-668

SMITH, G.D. e AANDAHL, A.R., 1957. Soil Classification and Survey. In: U.S. DEPARTAMENT OF AGRICULTURE. Soil washington, D.C., p.396-400. (Yearbook of Agriculture).

SOIL CONSERVATION, SERVICE, 1966. Aerial Photo-Interpretation in Classifying and Mapping Soils. In: UNITED STATES DEPARTAMENT OF AGRICULTURE. Soil Interpretation from Aerial Photographs. Washington, D.C. p.19-84.

SOIL SURVEY STAFF, 1962. Soil Survey Manual. United States Department of Agriculture. Washington. 503p. (Handbook 18).

SOUZA, M.L.P., 1975. Fotointerpretação das Redes de Drenagem de Três Solos com Horizonte B Latossólico Ocorrentes no Município de Ponta Grossa-PR. Piracicaba, ESAlQ/USP. 135p. (Dissertação de Mestrado). 
STRAHLER, A.N., 1956. Quantitative Slope Analysis. Bul. Geol. Soc. Am. 67:571-596.

STRAHLER, A.N., 1957. Quanțitative Analysis of Watershed Geomorphology. Transactions, American Geophysical Union, 38(6): 913-920, Dec.

STRAHLER, A.N., 1964. Quantitative Geomorphology of Drainage Basins and Channel Networks. In: CHOw, V.T. Handbook of Applied Hydrology. New York, McGraw-Hill Book, Sec. 4, p.II.

SUMMERSON, C.H., 1954. A phrlosophy for Photo Interprets. photogrammetric Engineering, 20: 412-417.

TOY, T.J., 1977. Introduction to the Erosion Process. In: EROSION; Research Techniques, Erodibility and Sediment Delivery. Norwich, Eng. Geo Abstracts, p.7-18

VALERIO FILHO, M., 1984. Parâmetros da Drenagem e do Relevo na Caracterização de Solos e suas Relações Fotointerpretativas em Imagers de Pequena Escala. Piracicaba, ESALQ/USP. 141p. (Tese de Doutoramento)

VASQUES FILHO, J., 1972. Critérios Morfométricos Aplicados à Fointerpretação de Redes de Drenagem em Três Unidades de Solos no Município de Piracicaba (SP). Piracicaba, ESALQ/USP. 113p. (Tese de Doutoramento). 
VETTORAZZI, C.A., 1985. Fotointerpretação de Bacias Hidrogrāficas e Redes de Drenagem em Cinco Solos da Região do Rio Ribeira de Iguape no Estado de São Paulo. Piracicaba, ESALQ/USP. 151p. (Dissertação de Mestrado).

VIEIRA, L.S., 1975. Manuat da Ciência do Solo. São Paulo, Editora Agronômica Ceres, 464p.

WEG, R.F., 1966. Patrones de Drenaje. Bogotá, Centro Interamericano de Fotointerpretaçión. 25p.

WENTWORTH, C.K., 1930. A Simplified Method of Determining the Average Slope of Land Surfaces. Am.J.Sci. 20(117):184-194

WONG, K.W., THORNBURN, T.H. e KHOURY, M.A., 1977. Automatic Soil Identification from Remote Sensing Data. Photogrammetric Engineering and Remote Sensing, 43(1):73-80.

ZINKE, P.J., 1960. Photo Interpretation of Soil. In: AMERICAN SOCIETY OF PHOTOGRAMMETRY. Manual of Photographic Interpretation. Washington, Cap. 10, p.539.560. 